\author{
UNIVERSIDADE DE SÃO PAULO \\ FACULDADE DE FILOSOFIA, LETRAS E CIÊNCIAS HUMANAS \\ DEPARTAMENTO DE HISTÓRIA \\ PROGRAMA DE PÓS-GRADUAÇÃO EM HISTÓRIA SOCIAL
}

BRUNO HÜBSCHER

Arnaldo Momigliano: História da historiografia e do mundo antigo

São Paulo

2010 


\author{
UNIVERSIDADE DE SÃO PAULO \\ FACULDADE DE FILOSOFIA, LETRAS E CIÊNCIAS HUMANAS \\ DEPARTAMENTO DE HISTÓRIA \\ PROGRAMA DE PÓS-GRADUAÇÃO EM HISTÓRIA SOCIAL
}

\title{
Arnaldo Momigliano: História da historiografia e do mundo antigo
}

Bruno Hübscher

Dissertação apresentada ao Programa de Pós-Graduação em História Social do Departamento de História da Faculdade de Filosofia, Letras e Ciências Humanas da Universidade de São Paulo, para a obtenção do título de Mestre em História Social.

Orientador: Prof. Dr. Francisco Murari Pires 


\section{Resumo:}

Em seis décadas de atividade, entre 1927 e 1987, Arnaldo Dante Momigliano (19081987) publicou mais de setecentos artigos e resenhas, que formam o corpus de sua obra. Em função da opção de Momigliano por estudos de extensão limitada, apresentados na forma de artigos e conferências, sua obra possui um caráter disperso, o que torna difícil uma visualização clara de sua totalidade. Ainda que compilada nos volumes dos Contributi publicados ao longo da vida do historiador (e após sua morte), tal compilação se apresenta problemática. A presente pesquisa visa propor um mapeamento da obra de Momigliano e uma discussão e contextualização da mesma, centrada nos principais focos de sua produção, com ênfase nas questões da história da historiografia e da paz e liberdade no mundo antigo.

Palavras-chave: Momigliano, Historiografia, Mundo Antigo, Estudos Clássicos, Antigos e Modernos.

\section{Abstract:}

In six decades of activity, between 1927 and 1987, Arnaldo Dante Momigliano (19081987) published more than seven hundred articles and reviews, which form the body of his work. Due to his option for studies of limited extension, presented in the form of articles and conferences, his work possesses a dispersed character, what makes a clear visualization of its totality difficult. Although compiled in the nine volumes of the Contributi published along the historian's life (and after his death), such compilation is problematic. The present research proposes to trace a map of Momigliano’s work and a discussion and contextualization of this work, centered in the main focuses of his production, with emphasis in the subjects of the history of the historiography and the peace and liberty in the ancient world.

Key-words: Momigliano, Historiography, Ancient World, Classical Studies, Ancients and Moderns. 


\section{ÍNDICE}

INTRODUÇÃO

\section{CAPÍTULO 1:}

Paz e liberdade no mundo antigo

\section{CAPÍTULO 2:}

História da historiografia 


\section{AGRADECIMENTOS}

O trabalho aqui apresentado teve início com meu ingresso no Programa de PósGraduação em História Social da Universidade de São Paulo, no primeiro semestre de 2007. Entre setembro de 2007 e agosto de 2009 me foi concedida bolsa de estudos da FAPESP, a qual me possibilitou dedicação integral às atividades da pesquisa no período e pela qual registro meu agradecimento à agência.

Agradeço ao Professor Francisco Murari Pires pela orientação e disponibilidade no decorrer da pesquisa e pelo encorajamento oferecido desde a apresentação do projeto de pesquisa, em meados de 2006.

À Professora Janice Gonçalves, pela ajuda no levantamento da bibliografia inicial e na elaboração do primeiro projeto.

Os resultados parciais da pesquisa foram apresentados no Exame de Qualificação a uma banca composta pelos professores Marcelo Rede e Breno Battistin Sebastiani, aos quais agradeço pelas considerações e comentários oferecidos na ocasião.

Aos colegas de orientação Rafael Benthien e Carlos Ogawa, pelas discussões, conversas e pelo apoio oferecido no decorrer dos últimos anos.

Karina Cutolo, pelo apoio e pela revisão do texto da dissertação.

Outras pessoas que de uma forma ou de outra ofereceram auxílio no período da realização da pesquisa: Ada Cutolo, Alice Cutolo, Marisa Hoeschele, Gábor Varga, Alain El Youssef, Paula Andrade Álvares, Newton Schner.

Por fim, agradeço à minha família, em especial meu pai, Hartmut, minha mãe, Elaine, minha irmã, Letícia, e também à minha avó Alzira e tia Rejane. 


\section{Introdução}

Arnaldo Momigliano é considerado um dos mais importantes e influentes historiadores do século XX. Sua contribuição para os campos da história antiga e, em especial, da história da historiografia e dos estudos clássicos, é amplamente reconhecida. Já na década de 1960, Moses I. Finley afirmava que "nenhum contemporâneo (...) contribuiu tanto para o estudo e a compreensão da tradição historiográfica ocidental [quanto Momigliano]”; ${ }^{1}$ Donald Kagan, na década de 1990, referia-se a Momigliano como "a principal autoridade em historiografia da Antigüidade em todo o mundo". ${ }^{2}$ Sua erudição e o amplo escopo de seus conhecimentos são freqüentemente sublinhados por seus comentadores.

Nascido em Caraglio, cidade da província de Cuneo, no norte da Itália, em setembro de 1908, Momigliano cresceu no contexto de uma distinta família judaica. Em meados da década de 1920, mudou-se para Torino, onde iniciou seus estudos na Faculdade de Letras da Universidade de Torino, vindo a concluí-los sob a orientação do eminente historiador italiano Gaetano De Sanctis. Em 1932 era nomeado professor associado de história grega na Universidade de Roma e iniciava sua contribuição na produção da Enciclopedia Italiana sob a tutela de Giovanni Gentile e Benedetto Croce. Em 1936, Momigliano era apontado para a cátedra de história romana na Universidade de Torino, da qual seria, no entanto, afastado em 1938, em conseqüência das leis raciais promulgadas pelo governo de Mussolini. No ano seguinte, em 1939, encontrava refúgio em Oxford, na Inglaterra, onde permaneceria até o final da Segunda Guerra.

Com o fim da guerra, em 1945, o historiador era restabelecido em sua cátedra em Torino e era, ao mesmo tempo, convidado pelo filósofo Benedetto Croce para assumir a direção do Istituto Storico que fundava em Nápoles. Momigliano decidiria, entretanto, permanecer na Inglaterra, ainda que mantendo sua cidadania italiana. Em 1947 e 1949 era apontado, respectivamente, para uma lectureship e uma readership na Universidade de Bristol, assumindo em seguida, em 1951, uma das cátedras de história antiga na University College London, na qual permaneceria até sua aposentadoria em 1975. Paralelamente ao seu trabalho regular na University College, Momigliano

\footnotetext{
${ }^{1}$ M. I. Finley, Uso e Abuso da História, São Paulo: Martins Fontes, 1989. p.75.

2 Donald Kagan, The New Criterion, v. 10, n. 7, March 1992.
} 
conduzia um seminário semanal no Warburg Institute, em Londres, do qual era membro honorário. A partir de 1964, passaria a atuar também como professor extranumerário na Scuola Superiore de Pisa, na Itália. Com sua aposentadoria em 1975, Momigliano estabelece vínculo com o meio acadêmico norte-americano, assumindo a posição de Alexander White Visiting Professor na Universidade de Chicago, onde passaria alguns meses todos os anos até o final de sua vida. Momigliano faleceu em setembro de 1987.

Em seis décadas de atividade, entre 1927 e 1987, Momigliano publicou mais de setecentos artigos e resenhas, que formam o corpus de sua obra, o qual, como observou Donald Kagan,

(...) tends to read more like a collection of separate essays about a common subject than like a fully integrated account that sets a problem and proposes a solution. In fact, Momigliano's favorite form was the learned essay, and he fortunately left us eleven volumes of them in his Contributi alla Storia degli Studi Classici e del Mondo Antico. ${ }^{3}$

Em função de sua opção por estudos de extensão limitada, que adquiriam o formato de conferências e artigos, a obra de Momigliano apresenta um caráter disperso, de forma que as principais áreas de seu interesse não aparecem com nitidez na grande variedade da sua produção. Ainda que compilada nos nove volumes dos Contributi, publicados entre 1955 e 1991, tal compilação se apresenta problemática, como observou F. R. D. Goodyear em resenha do Quinto Contributo de 1978:

\begin{abstract}
The arrangements of the items in Momigliano's Contributi as a whole is extremely unsatisfactory and inconvenient. Indeed one can scarcely talk of arrangement at all when juvenile efforts are set beside pieces written forty years later and papers on closely related subjects, published at much the same time, appear in different volumes. Momigliano says in the preface to the present installment that a more systematic and rational arrangement would only have been possible after his death. ${ }^{4}$
\end{abstract}

Diante da grande extensão da obra de Momigliano e de sua dispersão, um das premissas iniciais da presente pesquisa consistia na necessidade de um mapeamento desta obra, a partir do qual uma contextualização da produção do historiador nos temas de suas abordagens e no decorrer de sua carreira acadêmica seria conduzida, respeitando os limites impostos pelas fontes e documentos disponíveis. O projeto de pesquisa inicial identificava dois temas centrais na obra de Momigliano: a) a história da historiografia,

\footnotetext{
${ }^{3}$ Ibidem.

${ }^{4}$ F. R. D. Goodyear, “Continued Contributions”, in The Classical Review, New Ser., Vol.28, No.1. (1978), p.140.
} 
sobretudo na formulação proposta pelo historiador em The Classical Foundations of Modern Historiography, título sob o qual foram publicadas as Sather Lectures por ele ministradas em 1961 e 1962 na Universidade da Califórnia, em Berkley; b) o período helenístico e o sincretismo cultural na Antigüidade, tema recorrente na obra do historiador, sobretudo a partir da década de 1970, abordado em outra série de conferências, estas ministradas em maio de 1973 em Cambridge e entre fevereiro e março de 1974 no Bryan Mawr College, sendo mais tarde publicadas no volume Alien Wisdom: The Limits of Hellenization.

O levantamento e leitura das fontes, realizados tal qual previsto no projeto de pesquisa, possibilitou um mapeamento mais preciso dos principais temas de interesse que nortearam a produção de Arnaldo Momigliano no decorrer de sua trajetória intelectual. Este mapeamento levantou novos problemas e a necessidade de recortes mais precisos. Como observou Oswyn Murray, a metodologia de Momigliano pouco ou nada se alteraria ao longo dos anos de sua atividade, permanecendo ancorada, sobretudo, na erudição italiana de sua juventude, combinada a um respeito filológico pela evidência herdado do positivismo alemão, e à tradição filosófica de Benedetto Croce. A mesma continuidade pode ser observada nos temas e problemas de suas abordagens: "it is as if he had a program in mind from the start, and what changed was the focus of attention. Themes which became important at a later stage can usually be found prefigured in the writing of the Italian period”. ${ }^{5}$ Diante disto, o desenvolvimento do pensamento de Momigliano no período anterior ao exílio e nos primeiros anos na Inglaterra passa a figurar como fundamental para a compreensão de sua produção posterior, ganhando maior centralidade para a investigação.

Assim, a paz e a liberdade no mundo antigo, principais temas de pesquisa de Momigliano entre o início da década de 1930 e meados da década de 1940, constituem o objeto do primeiro capítulo da presente dissertação. Ainda que estes temas tenham norteado a pesquisa de Momigliano por mais de uma década, sua contribuição para o estudo dos mesmos é pouco comentada e reconhecida. Entre os motivos, destaca-se o fato de Momigliano jamais haver publicado os resultados de sua pesquisa a eles relacionados, os quais deveriam constar em um volume intitulado Liberty and Peace in Antiquity (from the fifth century B.C. to St. Augustin), para o qual o historiador teria, logo no início de seu exílio, assinado um contrato com a Oxford Clarendon Press. O

\footnotetext{
${ }^{5}$ O. Murray, "Momigliano in England", in History and Theory, vol. XXX, n.4, Beiheft 30, 1991, p. 62.
} 
projeto deste volume jamais viria a se materializar. Do andamento da pesquisa e de seus resultados parciais, restaram apenas anotações e esboços do historiador e os textos de conferências ministradas na Itália e na Inglaterra entre as décadas de 1930 e 1940, os quais permaneceram inéditos até a morte do historiador. Parte deste material permanece ainda inédito, disponível apenas no Archivio Arnaldo Momigliano em Pisa. Os principais textos relativos ao tema, entretanto, passariam a ser publicados a partir do final da década de 1980, mais notadamente o texto apresentado por Momigliano em Torino em 1936, na ocasião de sua leitura inaugural ao assumir a cátedra de história grega na Universidade de Torino, publicado por Carlo Dionisotti em seu Ricordo di Arnaldo Momigliano; ${ }^{6}$ as conferências apresentadas em Cambridge entre janeiro e março de 1940 sob o título Peace and Liberty in the Ancient World, publicadas por Riccardo Di Donato em volume traduzido para o italiano; ${ }^{7}$ e a conferência apresentada em Oxford em maio de 1940, igualmente intitulada Peace and Liberty in the Ancient World, publicada no nono volume, e primeiro póstumo, dos Contributi, organizado e compilado por Di Donato. ${ }^{8} \mathrm{O}$ acesso a esta bibliografia possibilitou a análise dos desenvolvimentos da pesquisa de Momigliano sobre o tema, para a qual o contexto político da Itália na década de 1930 e primeira metade da década de 1940, e o lugar específico que Momigliano nele ocupava, como judeu e historiador da antigüidade, exilado a partir de 1939, constituem elementos fundamentais para a compreensão dos rumos de sua produção.

O outro tema de interesse para a presente pesquisa, a história da historiografia, abordado no segundo capítulo da dissertação, surgia no contexto da obra de Momigliano a partir de meados da década de 1940, inaugurado mais especificamente em 1946, com o artigo Friedrich Creuzer and Greek Historiography. O novo direcionamento da pesquisa de Momigliano é o ponto de partida para a discussão proposta no capítulo. Com base nos diversos artigos publicados pelo historiador sobre historiografia antiga e, em especial, historiografia moderna, buscou-se estabelecer a forma como este pensava a história e os seus objetivos ao voltar o foco de sua pesquisa para a história da historiografia, tema marginal no campo dos estudos clássicos na Inglaterra no período

\footnotetext{
${ }^{6}$ C. Dionisotti, Ricordo di Arnaldo Momigliano, Il Mulino, Bologna, 1989, pp.109-130.

${ }^{7}$ A. Momigliano, Pace e libertà nel mondo antico - Lezioni a Cambridge: gennaio-marzo 1940, Firenze: La Nuova Italia Editrice, 1996.

${ }^{8}$ A. Momigliano, Nono contributo alla storia degli studi classici e del mondo antico, Roma: Edizioni di storia e letteratura, 1992, pp. 483-501.
} 
em questão. A posição de Momigliano, como judeu italiano exilado na Inglaterra sob tutela da Society for the Protection of Science and Learning, e sua decisão de permanecer na Inglaterra como emigré após a guerra, optando por não retornar à Itália, são questões relevantes no contexto da adoção de um tema marginal para a sua pesquisa. A questão remete, mais uma vez, aos anos anteriores ao exílio, período da formação de Momigliano em Torino e Roma, e sobretudo à sua relação com o filósofo Benedetto Croce.

Ainda que a história da historiografia viesse a constituir um tema recorrente nos estudos de Momigliano no decorrer de toda a sua produção a partir de meados da década de 1946, é possível se estabelecer com as Sather Classical Lectures, apresentadas em Berkley, em 1961-1962, sob o título The Classical Foundations of Modern Historiography (após as quais o foco da pesquisa de Momigliano dispersaria para outros temas), o ponto culminante do pensamento do historiador em relação ao tema. Os textos para estas conferências seriam revisados por Momigliano no decorrer das três décadas que se seguiram à sua primeira exposição no início da década de 1960, vindo a ser publicados apenas postumamente, em $1990 .^{9}$ A versão publicada do texto consiste em um arranjo das diversas versões do texto anotadas e modificadas pelo historiador no decorrer dos anos. Estando estas versões disponíveis apenas no Archivio Arnaldo Momigliano, na Itália, a discussão sobre o texto apresentada nesta dissertação constitui apenas uma discussão preliminar.

Outro tema importante na obra de Momigliano, para o qual o projeto chamava a atenção, consiste no período helenístico. O tema adquire centralidade entre as preocupações de Momigliano principalmente a partir da década de 1970, quando temos duas importantes publicações a ele relacionadas: o artigo The Fault of the Greeks, de 1975, e o volume Alien Wisdom: The Limits of Hellenization, publicado no mesmo ano, contendo o texto das conferências reunidas sob o título, apresentadas por Momigliano em Cambridge, em 1973, e no Bryn Mawr College, em 1974. ${ }^{10}$ Como a maioria dos temas que ocuparam Momigliano num período posterior de seus estudos, o helenismo já figurava entre os interesses do historiador no início de sua produção acadêmica. A sua experiência como judeu italiano e seu precoce contato com textos de diversas tradições

\footnotetext{
${ }^{9}$ A. Momigliano, As raízes clássicas da historiografia moderna, Bauru, SP: EDUSC, 2004.

10 A. Momigliano, Os Limites da Helenização: A Interação Cultural das Civilizações Grega, Romana, Céltica, Judaica e Persa, Rio de Janeiro: Jorge Zahar Editor, 1991.
} 
(grega, romana, judaica, renascentista etc) são relevantes para o contexto de sua abordagem, como será discutido brevemente no decorrer do primeiro capítulo.

Ainda que a história da historiografia constituísse o foco original da presente pesquisa e tenha constituído a primeira etapa de sua realização, a dissertação foi estruturada de forma a respeitar a ordem cronológica dos temas da produção de Momigliano, de maneira que o capítulo sobre o tema constitui seu capítulo final. O acesso à maior parte dos volumes dos Contributi (contendo a obra de Arnaldo Momigliano compilada, no que consistiam as fontes primárias para a pesquisa) foi viabilizado apenas tardiamente no andamento da pesquisa (em função de se tratarem de edições esgotadas, de difícil disponibilidade, e de entraves burocráticos para a sua aquisição por meio dos recursos da reserva técnica), de forma que grande parte da dissertação foi formulada com base nos artigos e textos disponíveis em diversas compilações e periódicos antes do acesso à totalidade da obra de Momigliano. Em função disso, algumas questões surgidas no final do período da pesquisa tiveram que ser colocadas de lado.

Nas considerações finais, um breve sumário dos principais argumentos da dissertação é apresentado, acompanhado do apontamento de questões para possível pesquisa futura. 


\section{Capítulo 1}

\section{Paz e liberdade no mundo antigo}

Com a publicação do manifesto della razza italiana, em agosto de 1938, e o advento das leis raciais, a política fascista anti-judaica passava a ser legalmente aplicada na Itália, desencadeando a progressiva exclusão da comunidade judaica da vida nacional italiana. Em dezembro do mesmo ano, como conseqüência, Arnaldo Momigliano era afastado da cátedra de história antiga que ocupava na universidade de Torino. Com o afastamento, o jovem historiador decide buscar no exterior uma possibilidade de dar continuidade à sua produção acadêmica e garantir sua sobrevivência, possibilidade que surgiria com uma bolsa de um ano oferecida pela Society of Protection of Science and Learning em Oxford, cuja concessão fora viabilizada pela mobilização do filósofo italiano Benedetto Croce, de Gaetano De Sanctis e de Hugh Last - o último tendo providenciado os detalhes do convite do historiador para a Inglaterra. Em janeiro de 1939, já com a oferta de bolsa da Society confirmada, Momigliano ainda contatava universidades norte-americanas em busca de outra oferta que lhe garantisse uma condição mais estável, como expressava em carta a De Sanctis. ${ }^{1}$ Em abril do mesmo ano, já em Oxford, Momigliano lhe enviava uma primeira saudação de terras estrangeiras.

O ano do exílio, 1939, marca o único ano sem publicações na vasta bibliografia de Momigliano, que se estende de 1928 a 1987. Já no ano seguinte, quatro resenhas de sua autoria figurariam em periódicos ingleses. Em 1984, Momigliano relembraria a necessidade da aquisição de uma nova língua e da absorção de uma nova cultura para lecionar como conseqüência da perseguição que sofrera na Itália. $^{2}$ Ainda que não possuísse domínio ativo da língua inglesa e já estivesse com trinta anos de idade ao migrar para a Inglaterra, poucos anos em Oxford foram suficientes para que a escrita da língua inglesa do historiador se tornasse soberba, como o qualificaria mais tarde um de

\footnotetext{
${ }^{1}$ L. Polverini, "Momigliano e De Sanctis", in L. Polverini (org.), Arnaldo Momigliano nella storiografia del novecento. Edizioni di Storia e Letteratura, Roma, 2006, pp. 22-23.
}

${ }^{2}$ A. Momigliano, Sui fondamenti della storia antica. Giulio Einaudi editore, Torino, 1984, p. VIII. 
seus estudantes do Warburg Institute. ${ }^{3}$ Outro aluno descreveu Momigliano como um “mestre da língua inglesa” nas páginas escritas. ${ }^{4}$ A pronúncia do inglês, entretanto, consistia em um problema para o historiador italiano, cujos seminários, ao contrário daqueles de outros emigrés de sua geração, não eram populares. Seu sotaque tornava suas leituras difíceis de serem acompanhadas e seus textos eram geralmente muito longos, sendo, por isso, lidos muito rapidamente. Diz-se que as audiências respeitavam seu entendimento dos problemas e sua erudição, mas apenas raramente se sentiam por ele inspiradas. $^{5}$

A despeito das dificuldades, Carlo Dionisotti considerou afortunado o fato de Momigliano ter encontrado refúgio na Inglaterra, mais precisamente em Oxford, onde se encontravam também exilados alguns dos maiores estudiosos alemães da Antigüidade - Fra enkel, Jacoby, Maas, Pfeiffer entre outrosde forma que não faltaram ao historiador italiano os instrumentos necessários e o estímulo para a realização de seu trabalho. ${ }^{6}$ Oswyn Murray propôs que a sociedade em que Momigliano viveu entre 1939 e 1947 não constituía propriamente a sociedade inglesa do período, mas um grande ajuntamento de estudiosos humanistas europeus. ${ }^{7}$ Murray oferece, em seu artigo Momigliano in England, um quadro das relações estabelicidas por Momigliano em seus primeiros anos em Oxford, sobretudo no contexto do grupo de pesquisadores formado em torno do Ashmolean Museum. ${ }^{8}$

Com o fim da guerra, este grupo de pesquisadores ao qual Momigliano estava integrado, dissolveu-se. Alguns dos estudiosos a ele ligados retornaram a seus países de origem, enquanto outros encontraram no novo mundo segurança financeira e condições de trabalho melhores do que aquelas que a Inglaterra do pós-guerra podia oferecer. Os que permaneceram acabaram assimilados pelo sistema acadêmico inglês. Em 1946, as

\footnotetext{
${ }^{3}$ A. Grafton, "Momigliano at the Warburg: the origins of a style", in American Scholar, Vol. 73, 4, September 22, 2004, p. 130. “(...) Yet within a few years, his written English became superb Tacitean, powerful, clipped idiom, vastly different from the more abstract and Ciceronian academic prose he had written as a young man in Italy. According to a witty saying that infuriated him, Momigliano wrote the second-best prose in Britain - after Gombrich, of course."

${ }^{4}$ O. Murray, "Momigliano in England", in History and Theory, vol. XXX, n.4, Beiheft 30, 1991, p. 62.

${ }^{5}$ Ibidem, p. 62.

${ }^{6}$ C. Dionisotti, Ricordo di Arnaldo Momigliano, Il Mulino, Bologna, 1989, p. 20.

${ }^{7}$ O. Murray, op. cit., p. 50.

${ }^{8}$ History and Theory, Vol. 30, No. 4, Beiheft 30: The Presence of the Historian: Essays in Memory of Arnaldo Momigliano. (Dec., 1991), pp. 49-64.
} 
possibilidades de um retorno à pátria estavam também abertas para Momigliano. No ano em questão, o historiador era restabelecido na cátedra de que fora afastado em 1937, em Torino; recebia também, durante sua breve estadia na Itália naquele mesmo ano, o convite de Croce para a direção de seu Istituto Storico. Momigliano acabou, entretanto, permanecendo na Inglaterra, ligando-se, em um primeiro momento, à Universidade de Bristol, onde fora designado a assumir uma lectureship, vindo a ser mais tarde promovido a reader. A decisão do historiador de permanecer na Inglaterra foi caracterizada por Murray como um momento decisivo em sua vida:

The decision to remain in England cannot have been an easy one, and he always retained his Italian citizenship. In retrospect this seems the turning-point in his life; for in choosing deliberately to remain an emigré, he set out on a path of independence which was to have enormous effect on the cultures of both England and Italy. ${ }^{9}$

Durante o período de sua atividade em Bristol, Momigliano continuou vivendo principalmente em Oxford, para onde retornava sempre que possível. Esta situação perdurou até 1951, quando finalmente viria a ocupar uma das três grandes cátedras de história antiga da University College London. Em 1952, fazia sua leitura inaugural como professor de história antiga na University College, intitulada Grote and the Study of Greek History - leitura que seria identificada por Karl Christ como o ponto culminante da preocupação de Momigliano com a história da historiografia no período pós-guerra. ${ }^{10} \mathrm{O}$ problema proposto no texto da leitura em questão dizia respeito aos caminhos da produção presente e futura relacionada à história da Grécia. Dentre as atribuições do responsável pela cadeira de história antiga da University College, que incluíam o ensino de história grega, romana e oriental, era a história da Grécia, segundo Momigliano, que oferecia as maiores dificuldades, tanto para professores quanto para pesquisadores.

O texto segue a abordagem que se tornaria padrão nos artigos de Momigliano sobre historiadores modernos, apresentando um panorama do contexto da produção da obra do historiador de seu interesse. Recua, dessa forma, à segunda metade do século XVIII, quando observa o surgimento de uma proposta de história da Grécia que

\footnotetext{
${ }^{9}$ O. Murray, “Arnaldo Momigliano (1908-1987)”, in The Journal of Roman Studies, Vol. 77. (1987), p. xi.

${ }^{10}$ K. Christ, "Arnaldo Momigliano and the history of historiography”, in History and Theory, vol. XXX, n.4, Beiheft 30, 1991, p. 8.
} 
incorporava discussões políticas, o que ocorre precisamente com o aparecimento das obras de John Gillies, em 1786, e de William Mitford, entre 1784 e 1810. Tais discussões, Momigliano percebia, giravam em torno de problemas contemporâneos: Gillies traça um paralelo entre Filipe da Macedônia e Frederico da Prússia, ao passo que Demóstenes e os democratas atenienses apareciam em sua obra como precursores dos rebeldes da Revolução Americana. Gillies escrevera também uma história que abrangia o período da morte de Alexandre ao reinado de Augusto, para a qual Momigliano aponta a possibilidade de um paralelo entre a conquista da Grécia pelos romanos e as conquistas de Napoleão na Europa. A dimensão do comprometimento político desta historiografia é marcada na proposta de Momigliano de uma revisão de idéias comuns a respeito de seu desenvolvimento, de acordo com as quais Niebuhr teria inaugurado a discussão sobre Demóstenes e Filipe, e Droysen teria descoberto a analogia entre Macedônia e Prússia. ${ }^{11}$

Gillies logo seria, de acordo com Momigliano, superado por Mitford, “chiefly because the later's History of Greece was richer and more reliable in scholarly details.” ${ }^{12}$ É com Mitford, portanto, que a geração seguinte de historiadores da Grécia iria dialogar diretamente: Grote, em 1826, lançava um ataque ao historiador em artigo de cinqüenta páginas publicado no Westminster Review, ao qual se sucederia um artigo anônimo, este em defesa de Mitford, no Quaterly Review. Logo o projeto de Grote de uma reapresentação da história da Grécia teria que competir não apenas com Mitford e seus defensores, mas também com Connop Thirlwall, cuja Greek History começava a circular na Inglaterra a partir de 1835.

Thirlwall e Grote faziam parte de sociedades distintas que apresentavam muitas características em comum: desgostavam de Mitford, almejavam a liberalização dos hábitos políticos e intelectuais ingleses e liam alemão. O grupo de Thirlwall, entretanto, sofria influência muito maior da tradição filosófica alemã, o que Momigliano aponta como o motivo, em última instância, para a obra de Grote haver se sobressaído à de Thirlwall:

There cannot be two opinions on Thirlwall's intellectual qualities. His scholarship was fine, his judgment sure; his straightforward and incisive style

\footnotetext{
${ }^{11}$ A. Momigliano. A.D. Momigliano: Studies in Modern Scholarship. University of California Press, Berkley, 1994. p. 18.

${ }^{12}$ Ibidem, p. 18.
} 
was better suited to historical writing than that of Grote. But he could not put his whole heart and mind into a Greek history as Grote could. (...) Grote found all that he wanted in ancient Greece: the origins of democratic government and the principles of freedom of thought and of rational enquiry. (...) Thirlwall really loved Germany; Grote loved Athens. ${ }^{13}$

Uma das grandes qualidades da obra de Grote seria, na apreciação de Momigliano, seu cuidadoso exame das evidências. A origem de sua paixão pelo exame rigoroso da evidência é apontada como conseqüência da influência de Sir George Lewis, membro dos Philosophic Radicals, sociedade da qual também Grote fazia parte. Foi tal respeito pela evidência que levou Grote à conclusão então revolucionária de que a história grega necessitava ser dividida em duas partes, a Grécia lendária e a Grécia histórica: "Grote never denied that the legends on early Greece might contain a good deal of history. He simply confessed his inability to separate history from myth without collateral evidence and without possibility of verification”. ${ }^{14}$

O que Momigliano enxergava como a grande distinção da obra de Grote, entretanto, era a combinação, a exemplo de Gibbon, das características do erudito com as do historiador filosófico. Ao seu profundo respeito pela evidência, Grote associava a paixão pelas questões morais e seus interesses políticos. Enquanto Mitford, seu antecessor, havia sido "a determined supporter of rights of kings," Grote, por sua vez, fora um defensor da democracia ateniense: "he interprets Greek democracy as the form of government coinciding not with the interests of the poor, but with the interests of society as a whole." ${ }^{15}$ Sua maior descoberta no campo do pensamento grego estaria, na percepção de Momigliano, no resultado de sua procura por relações entre democracia grega e progresso intelectual.

Por outro lado, as faltas e os limites da obra de Grote são apontados por Momigliano como bastante óbvios então, um século após sua composição. O erro mais notório do historiador estaria na identificação da liberdade na Atenas do século V a.C. como liberdade absoluta: Grote negligenciara o aviso de Benjamin Constant anos antes em seu ensaio clássico sobre as diferenças entre as idéias de liberdade antiga e moderna. Curiosamente, o juízo de Momigliano exclui o âmbito da crítica moral e política

\footnotetext{
${ }^{13}$ Ibidem, p. 21.

${ }^{14}$ Ibidem, p. 23.

${ }^{15}$ Ibidem, pp. 18-19.
} 
implícita na comemoração da liberdade ateniense que propunha Grote, justamente o âmbito que aponta como uma das grandes distinções da obra do historiador. A questão, como será proposto a seguir, remete ao contexto da juventude de Momigliano e ao tema que constituiu seu principal interesse no início de seus estudos até meados da década de 1940 - a liberdade no mundo antigo.

\section{II}

Em 1929, indo de Torino a Roma, Gaetano De Sanctis levava consigo dois de seus mais aplicados estudantes, Arnaldo Momigliano e Piero Treves - o último filho do distinto militante socialista italiano Claudio Treves. Entre os dois estudantes, Carlo Dionisotti reporta a ocorrência de alguns atritos. O primeiro deles, em 1929, ocorrera em torno de uma polêmica relacionada à crítica de Treves ao artigo Rileggendo il 'Ciclope' (Euripide Dichter der grieschischen Aufklärung) ${ }^{16}$ de Momigliano, no contexto da qual Gaetano De Sanctis intervém a favor de Treves. Ainda que, como observou Dionisotti, o alvo da intervenção de De Sanctis não fosse Momigliano, mas Gennaro Perrotta, um estudioso de outra escola, “le lodi che il maestro versava sull’uno, a piene mani, in misura insolita, invitabilmente suonavano come disapprovazione e monito all'altro."17

Em seguida, no início da década de 1930, quando Treves publicava um livro sobre Demóstenes, outro debate envolvendo os dois estudantes tinha início. O tema do conflito, a diferença entre a liberade de antigos e modernos, havia sido proposto pelo filósofo italiano Benedetto Croce em sua nota acadêmica de 1930, sobre Constant e Jellinek intorno alla differenza tra la libertá degli antichi e quella dei moderni, à qual Momigliano responderia, no ano seguinte, com uma breve resenha na Rivista di Filologia. Em sua nota, Croce criticava Jellinek por introduzir conceitos jurídicos no campo da filosofia, no qual perderiam sua qualidade de conceitos jurídicos e se tornariam conceitos semi-filosóficos, gerando hibridismos que corrompem o filosofar. Com relação ao memorando de Benjamin Constant de 1819, que inaugurara a discussão sobre a diferença entre a liberdade dos antigos e dos modernos, Croce chamava atenção

\footnotetext{
${ }^{16}$ A. Momigliano, Sesto contributo alla storia degli studi classici e del mondo antico. Roma, 1980, pp. 793-799.

${ }^{17}$ C. Dionisotti, op. cit., p. 623.
} 
para o simplismo de sua abordagem - fazia-se necessária uma investigação mais profunda sobre o tema. De acordo com o filósofo, a diferença entre a liberdade de antigos e modernos não pressupunha a existência de dois ideais de liberdade distintos:

[aquela proposta por Constant] Era un'indagine da proseguire, e, nel proseguirla, si sarebbe dovuto, da una parte, approfondire il contenuto e la genesi dell'ideale moderno di libertà, in relazione al simultaneo svolgimento del pensièro filosofico, e, dall'altra, correggere quel che di rigido e di semplicistico dava all'occhio nella contrapposizione di libertà antica e moderna, ricercando e dimostrando tutti i passaggi che, attraverso il cristianesimo, il medioevo, il rinascimento, la riforma, l'illuminismo, condussero gradualmente dall'una all'altra, e lumeggiando perciò la libertà antica non tanto come un diverso quanto come una prima forma della stessa coscienza moderna della libertà, una forma che questa risolve in sé, ma non certo respinge. ${ }^{18}$

A questão seria retomada por Croce posteriormente, na segunda metade da década de 1930, colocada então em termos de um problema de periodização e classificação:

Al classificar la historia, o sea al construir los periodos históricos, no sólo es admisible sino indispensable distinguir una libertad antigua y una libertad moderna, y distinguir también, mediante subdivisiones, otros periodos y otras libertades. Pero no es necesario, luego, que al fingir, para el fin antedicho, siga el creer (fingit creditque), esto es, el creer que las dos libertades, tan distintas por clasificación, sean realmente distinguibles; si en la libertad se pudieren discernir dos libertades, cada uma com su caráter particular, es evidente que, o una de las no seria libertad, o ambas serían expressiones imprecisas de una libertad única, superior y solo efectiva. ${ }^{19}$

Em sua réplica à nota de Croce de 1930, Momigliano propunha que a discussão sobre a diferença entre a liberdade dos antigos e dos modernos deveria partir de Constant e não de Jellinek, de forma que não entra nos méritos da argumentação de Croce a respeito do emprego de conceitos pseudo-jurídicos por Jellinek. Quanto à superficialidade da abordagem de Constant para a qual Croce chamava atenção, argumenta:

E se - come nota il Croce - la contrapposizione dei due concetti di libertà era semplicistica e trascurava «il cristianesimo, il medioevo, il rinascimento,la

\footnotetext{
${ }^{18}$ B. Croce. Etica e Politica. Bari: Gius, Laterza \& Figli, 1945, pp. 294-5.

${ }^{19}$ B. Croce. La Historia como Hazaña de la Libertad. Mexico DF: Fondo de Cultura Económica, 1960, p. 224.
} 
riforma, l'illuminismo», questo semplicismo giovò alla limpida posizione del problema e non può impedire ulteriori e più approfondite elaborazioni. ${ }^{20}$

Momigliano insiste no caráter jurídico da liberdade em um primeiro momento, no qual a liberdade se configurava como direito daqueles iguais no governo. O Estado, então condição necessária para a liberdade, passa, em determinado momento, a limitador da liberdade. É o que ocorre quando Filipe concede liberdade aos gregos: após a excitação inicial estes perceberam que a liberdade, quando concedida por um Estado externo, é em sua essência uma liberdade limitada.

Esta questão, entretanto, não correspondia à "experiência fundamental e definitiva do mundo antigo”, uma vez que dizia respeito, de acordo com Momigliano, mais a um problema de independência política, e não de verdadeira liberdade. É com a dissolução da consciência política e o rompimento do vínculo entre liberdade e forma de governo que teríamos, num segundo momento, o surgimento de uma liberdade humana, que não mais reconhece o Estado. O cosmopolitismo se torna a condição para esta liberdade, como nos cínicos, nos estóicos e nos primeiros cristãos. O vínculo entre liberdade e Estado é reatado apenas quando esta liberdade humana entra em choque com os interesses do Estado. O que Momigliano identifica como a experiência mais séria do mundo antigo é aquela do judaísmo e do cristianismo, na qual os direitos de crença eram limitados ou negados em função das demandas do Estado. A solução que o mundo antigo encontra para este conflito, como observava o historiador, não ocorre com a afirmação da necessidade do Estado, mas com a submissão do mesmo à consciência religiosa:

Conflitto tra la legge interna, cioè la libertà, e la legge esterna, che il mondo antico risolve non affermando la necessità di uno Stato, il quale ammetta $\mathrm{i}$ contrasti e viva di questi, ma andando alla conquista dello Stato medesimo e sottomettendolo alla coscienza religiosa. Ciò che si fece così nella cristianizzazione dell'Impero romano, come nella disperata lotta degli Ebrei per ricostruire il loro Stato, che, senza tale presupposto, dovrebbe considerarsi (e fu considerata) una pazzia. ${ }^{21}$

É nesta liberdade que não depende nem se contrapõe, mas que submete o Estado, que Momigliano identifica um cintilar da liberdade moderna. É com o cristianismo que

\footnotetext{
${ }^{20}$ A. Momigliano, Quinto contributo alla storia degli studi classici e del mondo antico. Roma, 1975. p. 906.

${ }^{21}$ Ibidem, p. 907.
} 
o eixo do problema da liberdade é deslocado da independência política para o livrearbítrio, de forma que “(...) la liberté de Démosthène n'était pas la liberté du Christ.”22 Para Momigliano, estas questões constituiriam pontos fundamentais para a discussão sobre a diferença entre a liberdade dos antigos e a liberdade dos modernos. Era inevitável, portanto, uma reação negativa de sua parte em relação ao estudo sobre história da Grécia de seu colega Piero Treves, no qual o nascimento da liberdade moderna era identificado em Demóstenes:

(...) E intollerabile era per Momigliano la classicistica baldanza del rivale Treves, che intitolava il suo libro su Demostene alla libertá greca, 'scaturigine della nostra libertà', e si proclamava erede e seguace di 'queli storici che, nell’Ottocento, seppero, per la libertà operare e combaterre.’”23

Treves identificava em sua obra sobre Demóstenes a oposição entre a interpretação proposta por Droysen, que exaltava a superação da liberdade das poleis gregas com o Estado de Filipe, e as interpretações de Niebuhr e Grote, que mantinham a crença no valor da liberdade de Demóstenes, aderindo pessoalmente ao segundo ponto de vista. Momigliano, em sua resenha da obra em questão, reclama que esta adesão pessoal de Treves é apontada sem que uma interpretação do pensamento de Grote, Niebuhr ou Droysen fosse oferecida. As menções a estes autores a partir das quais, por afinidade ou contraste, Treves deriva seu pensamento, eram, de acordo com Momigliano, demasiado genéricas, e em momento algum o autor oferecia uma definição clara da liberdade grega defendida por Demóstenes, a qual apontava recorrentemente como precursora da liberdade moderna. Diante disso, Momigliano acusa Treves de fazer “história de um objeto desconhecido”. ${ }^{24}$ Eliminando-se a ideologia da unidade nacional da história da Grécia, o conteúdo do livro de Treves seria, de acordo com Momigliano, indeterminado. Esta indeterminação Momigliano observa igualmente nas leituras oferecidas por Niebuhr e Grote, que da mesma forma que Treves não definiam a liberdade grega de que falavam. A este argumento, já prefigurado na resenha do livro de Treves de 1933, Momigliano retomaria, como visto, em sua leitura inaugural sobre Grote em 1950.

\footnotetext{
${ }^{22}$ A. Momigliano, Philippe de Macedoine: essai sur l'histoire grecque du iv siecle av.j.-c. Paris: L'eclat, 1992, p. 12.

${ }^{23}$ C. Dionisotti, op. cit., p. 624.

${ }^{24}$ A. Momigliano, Quinto contributo alla storia degli studi classici e del mondo antico, Roma: Edizioni di storia e letteratura, 1975, p. 938.
} 
A posição de Momigliano frente à questão, como atestou no prefácio à reedição de 1987 de seu livro Filippo il Macedone, refletia a sua situação como judeu no contexto político e cultural daquele período: “avait fort à se préoccuper de ses libertés politiques mais aussi de ses libertés religieuses.” 25 A iminência de uma passagem da propaganda anti-semita à perseguição dos judeus pelo regime fascista marcava este contexto, no qual o envolvimento de Momigliano e sua militância dentro da comunidade judaica italiana, sobretudo a partir de 1936, período em que deixava Roma e retornava a Torino, é ilustrado em uma série de documentos compilados por Riccardo Di Donato em seu artigo Materiali per una biografia intellettuale di Arnaldo Momigliano. ${ }^{26}$

A discussão acerca do problema da liberdade, entretanto, proposta na Itália no início da década de 1930 em função dos eventos políticos transcorridos no período, se colocava de forma diversa para Momigliano e para seus maestri De Sanctis e Croce. A reação positiva destes em relação ao Demostene e la libertà greca de Piero Treves era conveniente no contexto em que esta surgia, independente de sua validade histórica, como bem observou Carlos Dionisotti: "bisogna riconoscere oggi che quella commemorazione della libertà, antica e moderna, Constant incluso, era allora politicamente opportuna, quale che ne fosse la validità storica..." ${ }^{27}$ A apreciação da obra de George Grote oferecida por Momigliano em 1952, na qual o historiador inglês é criticado por haver negligenciado o aviso de Constant, incorre em um problema semelhante: da mesma forma que o paralelo entre a liberdade de antigos e modernos era oportuno no contexto da década de 1930 na Itália, era também oportuno para o contexto da crítica pretendida por Grote em sua história da Grécia na primeira metade do século XIX. Ao centrar sua apreciação na questão da validade histórica do paralelo entre antigos e modernos, tomando-o por incongruente, Momigliano perde de foco seu sentido subjacente, deixando escapar em sua análise a dimensão crítica intencionada pelos autores.

\footnotetext{
${ }^{25}$ A. Momigliano, Philippe de Macedoine: essai sur l'histoire grecque du iv siecle av.j.-c. Paris: L'eclat, 1992. p. 11.

${ }^{26}$ R. Di Donato, “Materiali per una biografia intellettuale di Arnaldo Momigliano”, in: Athenaeum Studi di Letteratura e Storia dell'Antichità. Volume Ottantatreesimo, Fascicolo 1, Università di Pavia, 1995, pp. 213-244.

${ }^{27}$ C. Dionisotti, op. cit., p. 624.
} 
O período de Momigliano em Roma, iniciado em 1929, foi marcado sobretudo por sua contribuição com a Enciclopedia Italiana, para a qual escreveu uma série de artigos, entre eles Roma in età imperiale ${ }^{28}$ e diversos verbetes biográficos de personalidades da antiguidade - como Caligula, Córbulo, Demétrio de Falero, Nero etc, além de um verbete sobre o historiador alemão Eduard Meyer, que pressagia seu trabalho posterior sobre grandes historiadores modernos da antiguidade. Em 1936, Momigliano deixa Roma em função de sua convocação para a cátedra de história romana da Universidade de Torino, pela qual respondia anteriormente seu antigo professor Gaetano De Sanctis, afastado por recusar-se a prestar o juramento fascista. Carlo Dionisotti, em seu Ricordo di Arnaldo Momigliano, oferece detalhes sobre o concurso para a cátedra, do qual entre dez concorrentes, Momigliano, o mais jovem entre eles, obteve melhor êxito. ${ }^{29}$

De um ponto de vista intelectual, o período de Momigliano em Roma se encerrava com a composição do texto de sua leitura inaugural, pronunciado em Torino em dezembro de 1936, intitulada Koiné Eirene, Pax Romana, Pax Christiana. ${ }^{30} \mathrm{O}$ próprio autor, em 1982, anotava na cópia datilografada do texto, que seria publicado apenas postumamente: “da pubblicarsi solo con avvertenza sulla situazione politica e personale di chi ebreo e non fascista si trovava a parlare.” Carlo Dionisotti, colega de faculdade em Torino e amigo pessoal de Momigliano, com quem manteve estreito contato durante a maior parte de sua vida, tomou para si a tarefa da publicação da leitura. A nota de Dionisotti que acompanha o texto chama a atenção para a "quase milagrosa integridade e honestidade da leitura," pronunciada no contexto de “indecente servilidade imperial” do ano de 1936. Dionisotti afirma não haver encontrado no texto nada que justificasse a nota de 1982. Mais que a data da leitura, propõe, a data da nota

\footnotetext{
${ }^{28}$ Republicado em A. Momigliano, Sesto contributo alla storia degli studi classici e del mondo antico, Roma: Edizioni di storia e letteratura, 1980, pp. 591-673.

${ }^{29}$ C. Dionisotti, Ricordo di Arnaldo Momigliano, Bologna: Il Mulino, 1989, pp. 88-90.

30 O texto da leitura inaugural de Momigliano em 1936 permaneceu inédito até 1989, quando foi publicado em C. Dionisotti, Ricordo di Arnaldo Momigliano, Bologna: Il Mulino, 1989, pp. 97-130, e posteriormente em A. Momigliano, Nono contributo alla storia degli studi classici e del mondo ântico, Roma: Edizioni di storia e letteratura, 1992, pp. 409-423, sob o título "Koiné Eirene, Pax Romana, Pax Christiana”, o qual é ausente no texto original, indicado em um memorando autobiográfico não datado (provavelmente do final de 1945).
} 
deve ser considerada. Apresenta assim um quadro do amadurecimento intelectual de Momigliano com base nos prefácios por ele escritos para os volumes dos Contributi publicados entre as décadas de 1960 e 1980, chamando atenção para a polêmica envolvendo a resenha de 1981 do livro Ideologie del Classicismo, de Luciano Canfora, na qual Momigliano precisou pela primeira vez, de acordo com Dionisotti, defender a si mesmo e à sua geração, e também a de seus maestri, do ataque de uma nova geração. ${ }^{31}$

Ainda que a cátedra de Momigliano em Torino fosse restrita à história romana, a leitura inaugural reafirmava, como observou Dionisotti, sua competência como historiador de toda a Antigüidade. Como indica o título, a pax romana divide o quadro da exposição de Momigliano com as idéias de paz helênica e cristã. O historiador justifica sua abordagem negando, no presente, qualquer valor à contraposição entre mundo grego e romano, a qual identifica como própria do romantismo alemão. A tradição humanística seria, segundo ele, tanto grega quanto latina em sua origem, de forma que Grécia e Roma estariam indissoluvelmente ligadas no espírito contemporâneo. A originalidade de Roma é por Momigliano afirmada na sua assimilação consciente da cultura grega: pela primeira vez na história da humanidade um povo não em decadência, mas no auge de sua expansão política e vitalidade moral, buscara conscientemente a civilização de outro povo, afirmando, justamente nessa escolha, sua autonomia. A inserção de ideais gregos na distinta experiência política romana resultara, de acordo com o historiador, na formulação de valores ético-políticos inteiramente novos, dos quais a transformação do conceito de paz nos mundos grego e romano, o qual propõe delinear sumariamente em sua leitura, constituiria um exemplo.

A discussão se inicia com a contraposição entre eirene grega e pax romana, seguida por uma discussão do desenvolvimento do conceito de eirene e o advento do ideal helênico de paz comum. Momigliano observa que, em um primeiro momento, os gregos não conheciam a paz como estado permanente de relação internacional - a guerra era o estado normal, a paz consistia em um período de trégua de duração prédeterminada, selado por um ato ritual, o spondai. A pax dos romanos, por sua vez, consistia já em um estado permanente desde a sua mais antiga acepção. O direito público romano não conhecia tratados de paz, apenas de aliança, cujo resultado era um

\footnotetext{
${ }^{31}$ A resenha Momigliano para L. Canfora, Ideologie del Classicismo, Torino: Einaudi, 1980, aparece republicada em Momigliano, Settimo contributo alla storia degli studi classici e del mondo antico, Roma: Edizioni di storia e letteratura, 1984, pp. 513-519.
} 
estabelecimento permanente de relações, no que consistia a pax. Para os romanos, o vencedor oferecia a paz aos vencidos da mesma forma que os deuses ofereciam a paz aos humanos. A paz como relação entre deuses e homens era estranha aos gregos, a pax deum constituía uma característica distintiva da religião romana, que correlativamente não conhecia, como a helênica, a paz como divindade.

No V século a.C., os gregos experimentaram um período de solidariedade internacional durante a guerra persa, ao qual se sucedeu um dissídio insolúvel com a guerra do Peloponeso. Durante o IV século, alimentaram a esperança de um retorno à solidariedade que marcara o período anterior. Nesse momento, Eirene entra para o vocabulário jurídico como paz permanente, em contraposição à trégua provisória determinada pelo spondai. Koiné eirene, a paz comum, surge então como um ideal elaborado pelos gregos que visava o estabelecimento da vida helênica e a afirmação da comunidade nacional. Este ideal, no entanto, viria a ser alcançado somente através de uma intervenção estrangeira: a primeira koiné eirene é estabelecida pelos espartanos e se torna instrumento de sua hegemonia - estes respondiam agora, entretanto, a uma potência maior não-helênica, a Pérsia.

A reação à paz ditada pelos persas argumentava que a realização de uma paz comum não pressupunha necessariamente a intervenção estrangeira. Em oposição à koiné eirene nascida da discórdia entre os gregos, propunha-se uma koiné eirene que resultasse de uma efetiva concórdia entre eles. Para Isócrates, a verdadeira eirene seria resultado de uma homonoia. Paradoxalmente, Isócrates convocava Filipe da Macedônia para que, como rei grego de estirpe bárbara, estabelecesse a concórdia entre os gregos, abandonando a ilusão do fim do domínio persa sem que outra nação estrangeira tomasse seu lugar e garantisse a paz comum entre os Estados helênicos. Assim, em 338 a.C., Filipe fundava a liga de Corinto, cujo principal propósito consistia na manutenção da koiné eirene. A ideologia de paz que havia facilitado o domínio persa sancionava agora o domínio macedônio.

A paz comum, entretanto, estava destinada a passar de um instrumento nas mãos dos macedônios para as mãos dos romanos. Momigliano alude à descoberta de Elias Bickerman de que a paz firmada entre Roma e Macedônia em 205 a.C. constituía uma koiné eirene, através da qual os romanos garantiam, juntamente com os macedônios, a 
autonomia e liberdade das cidades gregas. ${ }^{32}$ A invasão romana em 201 a.C., cuja motivação real Momigliano não discute, ocorrera sob o pretexto da violação da koiné eirene pelos macedônios. A liberdade helênica passava assim da tutela macedônia à tutela romana: em 196 a.C., o general romano Flaminino proclamava a liberação das cidades gregas, reafirmando mais uma vez o ideal da paz comum.

A segunda parte da leitura de Momigliano é centrada no desenvolvimento da idéia de pax romana, em um recorte que se estende da passagem da república ao império e deste ao advento do cristianismo. A insistência dos gregos em pensar a paz como concórdia interna teve, de acordo com o historiador, ressonância imediata entre os romanos, que entre o I e o II séculos a.C. viviam seus conflitos internos mais intensamente que sua rápida marcha de domínio do Mediterrâneo. A pax romana e a eirene-omonoia grega habitaram assim, por mais de um século, a mente dos romanos, até que, com César e Augusto, a concórdia era elevada à essência da pax romana entre os povos, imposta pela Roma imperial. Roma identificava sua própria superioridade com o dare leges pacis e seguia no sentido de uma organização cada vez mais sistemática dos povos sob seu domínio, semeando em torno de si o que para Momigliano constituía uma unidade espiritual assegurada pelo direito. A pax romana ou pax augusta, dessa forma, não se tratava de uma omonoia entre povos apenas, "ma di una estensione di quelli che sono i principi basilare della vita pubblica romana a tutti i popoli, in modo che il diritto romano fatto universale sia ragione di concordia, e perciè di pace, tra i popoli." 33

A pax augusta resolvia assim, na interpretação de Momigliano, o problema político da convivência entre os homens; não resolvia, entretanto, o problema religioso da existência humana. Este argumento o autor justifica sublinhando a demanda estóica por uma paz do espírito, em contraposição à paz exterior oferecida pelo império. O advento do cristianismo, da igreja e do ideal de pax christiana (e a relação entre estes, o império e a pax romana) é proposto como uma reação à questão religiosa e moral que o império falhara em solucionar com a pax romana. O problema da paz se desenvolvera, assim, de uma questão de prosperidade interna de um grupo homogêneo a uma questão

\footnotetext{
${ }^{32}$ E. Bickerman, "Les préliminaires de la seconde guerre de Macédoine", in Revue de Philologie, 61, 1935, pp. 58-81.

${ }^{33}$ A. Momigliano, Nono contributo alla storia degli studi classici e del mondo antico, Roma: Edizioni di storia e letteratura, 1992, p. 419.
} 
de ordem jurídica do convívio entre todos os homens, para finalmente se tornar uma questão de salvação com o cristianismo.

O primeiro contrato de Momigliano com a editora da universidade de Oxford, ainda no início de seu exílio, teria sido para a publicação de um livro sobre a história da paz e da liberdade no mundo antigo, tema que, de acordo com Oswyn Murray, “ilustrava perfeitamente bem a patronagem esclarecida exercida por Sisam - tópico e relevante no mundo de 1940, mas também apropriado aos talentos de um estudioso versado na tradição italiana e atento ao trabalho de Croce". ${ }^{34}$ Independente da patronagem exercida por Keneth Sisam - secretary of the delegates da Clarendon Press da Universidade de Oxford e também secretário do comitê que mais tarde se tornaria a Society for the Protection of Science and Learning -, a paz e a liberdade no mundo antigo já constituíam problemas centrais na pesquisa de Momigliano durante a década de 1930, como evidenciam o comentário à nota de Croce de 1932, sobre a diferença entre a liberdade de antigos e modernos, e a leitura inaugural de 1936, sobre a o desenvolvimento do ideal de paz na antiguidade. A atenção de Momigliano à obra do filósofo Benedetto Croce, por outro lado, parece ter sido decisiva para a eleição do tema pelo historiador. A filosofia de Croce ecoava o preceito hegeliano de que a história é a história da liberdade. Em Hegel e em seus repetidores (Croce faz menção a Cousin e Michelet), entretanto, o preceito assume o significado de uma história do nascimento da liberdade e de seu desenvolvimento - "mondo orientale, mondo classico mondo germanico; uno solo libero, alcuni liberi, tutti liberi” -, enquanto no contexto da filosofia croceana este preceito adquire diferente significado, como propôs o próprio filósofo em 1938, em sua obra La storia come pensiero e come azione:

Con diversa intenzione e diverso contenuto quel detto [do preceito da história da liberdade com o significado que assume na formulação proposta por Hegel] è qui pronunziato, non per assegnare alla storia il tema del formasi di uma libertà che prima non era e um giorno sarà, ma per affermare la libertà come l'eterna formatrice della storia, soggetto stesso di ogni storia. ${ }^{35}$

\footnotetext{
${ }^{34}$ O. Murray, "Momigliano in England”, in History and Theory, vol. XXX, n.4, Beiheft 30, 1991, p. 53.

${ }^{35}$ B. Croce, Filosofia, poesia, storia. Milano - Napoli: Riccardo Ricciardi Editore. p. 520.
} 
É partindo deste fundamento croceano que Momigliano desenvolve, no início da década de 1940, o princípio teleológico de sua produção histórica, o qual envolvia a identificação das diferentes formas de manifestação da liberdade nos diferentes contextos históricos:

Liberty is the eternal force of human activity. (...) But liberty has historical manifestations of widely different character. The task of the historian is to recognize without any polemical deformation the historical forms of the problem of freedom during the centuries. Historians see with desperation or with satisfaction - in conformity with their personal outlook - centuries of history turning without any apparent sign of freedom. Such are the centuries of the Roman Empire. These historians do not ask whether liberty assumed forms which are different from political freedom, whether human dignity which was expelled from the field of political life, did not take refuge in the more inaccessible fields of spiritual life. ${ }^{36}$

O livro sobre paz e liberdade no mundo antigo à Oxford Press partia desta premissa. Em relação ao livro, Riccardo Di Donato fornece alguns documentos importantes em seu artigo Materiale per uma biografia intellettuale di Arnaldo Momigliano, ${ }^{37}$ entre eles um caderno datado de 1940, contendo, entre registros, programas de trabalho e listas bibliográficas, um projeto endereçado ao editor:

1) Estou preparando um livro [sobre] "Liberdade e Paz na Antiguidade" (do V século a.C. a Santo Agostinho). As linhas gerais deste livro podem ser vistas em meu texto lido para a Oxford Philological Society, mas com duas diferenças: a) o livro será analítico b) levará em conta o funcionamento das instituições políticas.

2) Um livro deste tipo pressupõe, obviamente, uma história geral do desenvolvimento do pensamento político clássico. Como um trabalho que forneça este desenvolvimento não existe, eu mesmo o prepararei. Por isso, gostaria de enfatizar a idéia de um manual do pensamento político antigo:

a) o manual será do tipo da Geschichte der neueren Historiographie de E. Fueter.

b) ele deverá acentuar as linhas do pensamento político que ligam Grécia a Roma ao início do cristianismo, constituindo conseqüentemente a base da história das idéias políticas e morais no Império Romano. O autor não esquece que ele é principalmente um historiador do Império Romano.

c) No momento, não considero ir além do II século d.C. (até Tertuliano), já que não tenho conhecimento suficiente sobre os Padres Gregos da Igreja do III e IV séculos d.C. (espero, ainda, haver obtido tal conhecimento para o livro sobre

\footnotetext{
${ }^{36}$ A. Momigliano, Pace e libertà nel mondo antico - Lezioni a Cambridge: gennaio-marzo 1940, Firenze: La Nuova Italia Editrice, 1996, p. xxvi.

${ }^{37}$ R. Di Donato, “Materiali per una biografia intellettuale di Arnaldo Momigliano”, in: Athenaeum Studi di Letteratura e Storia dell’Antichità. Volume Ottantatreesimo, Fascicolo 1, Università di Pavia, 1995, pp. 213-244.
} 
Liberdade). Por outro lado, não é segredo que a história do pensamento político cristão foi estudada de forma muito melhor que a história do pensamento político pagão.

d) Duas características do livro devem ser consideradas: I) as implicações econômicas das teorias políticas II) os muitos tratados militares na medida em que envolvam teorias políticas.

e) Não creio que farei descobertas sobre Platão e Aristóteles. O conhecimento de suas posições e influência na história geral do pensamento clássico-cristão, entretanto, pode ser melhorado - e as Leis de Platão nunca foram examinadas por um historiador.

3) Se a leitura dos textos antigos e o contato com a literatura moderna para tal história do pensamento político deve estar em grande medida completos antes da publicação do livro sobre Liberdade, refletindo creio que seria bastante desejável terminar e publicar o livro sobre Liberdade primeiro.

4) Sob as atuais condições, talvez seja inútil sugerir uma data para a publicação de qualquer um dos dois livros. É minha precisa intenção ter o livro sobre liberdade pronto em dois anos, se for possível trabalhar tempo integral [na sua composição]. Uma quantidade considerável de textos modernos sobre liberdade precisa ser digerida paralelamente, já que o livro não teria valor sem um entendimento claro da natureza e desenvolvimento da liberdade. Este tipo de livro possui claros interesses teóricos.

Ao projeto, seguia-se um registro contendo o título e índice do livro, como proposto e idealizado pelo historiador:

Liberdade e Paz dos Persas a Sto. Agostinho

Introdução. O problema da diferença entre liberdade moderna e antiga no pensamento histórico do século XIX.

I. Liberdade como autonomia, independência como democracia no V século a.C. Heródoto, Tucídides, pseudoXenofonte, os sofistas. Os pressupostos não escritos da liberdade: cidadania, escravidão, riqueza.

II. Filosofia vs. democracia, Platão 30pp

III. Macedônia vs. democracia, Demóstenes 25pp

IV. O desenvolvimento da idéia de paz no IV e V séculos a.C.

A koiné eirene. Paz e Liberdade. 20pp

V. Paz da alma como liberdade: cínicos, estóicos e epicuristas.

A nova parrhesia.

VI. Paz republicana e libertas (Salústio, Varrão etc.) 20pp

VII. A oposição estóica 35pp

VIII. A oposição estóica 25pp

IX. Do ideal de paz judaico ao cristão. Liberdade como paz em deus. O fim da liberdade política.

X. O problema da tolerância religiosa no Império. 25pp 
O projeto do livro, nestes termos proposto em 1940, constitui uma primeira organização sistemática das questões com as quais Momigliano se ocuparia nos primeiros anos de seu exílio. A leitura para a Oxford Philological Society, pronunciada em maio de 1940, à qual o texto do projeto faz alusão, fora precedida por uma série de lições pronunciadas em Cambridge entre janeiro e março daquele mesmo ano, das quais a leitura de maio, consideravelmente mais breve, derivava. As lições de Cambridge consistem em um esquema de oito pontos, que coincidem em parte com os temas propostos para os capítulos do livro sobre paz e liberdade, sendo eles: I. La ricerca moderna sull'impero; II. Che cos’è la crisi della republica; III. Pace; IV. Libertà degli antichi; V. Libertà dei moderni; VI. Euletheria; VII. Libertas; VIII. Dalla libertà filosofica a quella cristiana. ${ }^{38}$

A primeira argumentação da primeira das lições de Cambridge partia de uma questão pessoal. O problema proposto é relativo ao valor histórico do império romano:

Per molti anni, come ben si sa, politici e giornalisti italiani hanno esagerato nel parlare dell'impero romano, confrontando e confondendo condizioni antiche e moderne. Così, la reazione naturale delle persone ragionevoli consisteva in una diffusa diffidenza riguardo ad ogni fatto riguardante la storia romana. Ma, allo stesso tempo, il valore dell'impero romano sembrava un problema per la morale e per la coscienza politica moderna. Era facile trovare una risposta efficace o prudente alle domande dei propri scolari sul reale valore dell'impero e delle sue figure più rappresentative. Era difficile dare una risposta vera. La medesima difficoltà io trovai accresciuta quando mi fu richiesto di screvire un sommario di storia dell'impero romano per l'Enciclopedia Italiana. La difficoltà consisteva, com'è abbastanza ovvio, nell'eliminare dalla questione le interferenze moderne mentre se ne conservava, allo stesso tempo, il carattere di problema della coscienza moderna. Quel che non ha valore non ha storia. I valori storici non sono materia di polemica ma di chiara conoscenza. Ne risultà naturalmente che l'interpretazione dell'impero romano divenne vieppiù una valutazione congiunta della civiltà pagana nel suo declino e della civiltà cristiana nel suo aparire. Il problema fu trapiantato sul suo proprio terreno: era il problema reale della fondazione della nostra vita moderna. Poteva avvertire nei miei scolari un più vivo interesse e un minore sospetto. ${ }^{39}$

\footnotetext{
${ }^{38}$ Uma tradução italiana do texto das lições de Cambridge é publicada em A. Momigliano, Pace e libertà nel mondo antico - Lezioni a Cambridge: gennaio-marzo 1940 (a cura di Riccardo di Donato), Firenze: La Nuova Italia Editrice, 1996. O texto original em inglês permanece inédito, constando como item no Archivio Arnaldo Momigliano em Pisa, Peace and Liberty in the Classical World lezioni University of Cambridge 1940 [Bibl. 208 quarter] P-a 1ms.

${ }^{39}$ A. Momigliano, Pace e libertà nel mondo antico - Lezioni a Cambridge: gennaio-marzo 1940, Firenze: La Nuova Italia Editrice, 1996, p. 4.
} 
A abordagem desta questão, por sua vez, parte de um ponto de vista menos pessoal. Os quatro volumes sobre história do império romano da Cambridge Ancient History constituem seu ponto de partida, visando estabelecer o diálogo entre o leitor italiano e sua audiência de Cambridge. Momigliano propõe que os volumes da Cambridge Ancient History constituiriam a primeira história do império romano digna de tal título desde a Histoire des Empereurs de Tillemont, publicada entre os anos de 1690 e $1738,{ }^{40}$ o que implica um período de pelo menos dois séculos sem que uma obra historiográfica relevante sobre o império romano fosse produzida. Comentando rapidamente as principais obras de história romana de Gibbon a Rostovzeff, cobrindo entre eles uma longa lista de autores - Niebuhr, Mommsen, Savigny, A. Thierry, Fustel de Colanges, E. Meyer, G. De Sanctis, M. Holleaux, Münzer, B. Borghesi, Duruy, Merivale, Schiller, A. Harnack, Hirschfeld, von Domaszewski e Dessau -, Momigliano aponta o contraste entre a obra "enormemente produtiva e plena de idéias” sobre a república e o baixo império produzida desde o século XVIII e a escassez de obras sobre os primeiros três séculos do império romano. Chama a atenção também para o caráter predominantemente antiquário e jurídico da pesquisa histórica sobre o império, em contraste com o caráter historiográfico dos estudos sobre a república e o império tardio. Ao inquirir sobre os motivos de tal quadro, retoma a discussão já proposta anteriormente no artigo La formazione della moderna storiografia sull'empero romano, de $1936,{ }^{41}$ a qual dizia respeito, sobretudo, à relação entre império romano e igreja e os limites objetivos desta relação como o problema fundamental do império.

Momigliano afirma que a principal característica do império romano, sua universalidade, não poderia ser compreendida sem que se reconstruísse e definisse, ao mesmo tempo, a universalidade da igreja, que com o império cresce e a ele se contrapõe, dele tornando-se força intrínseca. Dar uma unidade à história da igreja e à história do império significaria dar um senso concreto ao império romano, o que não seria possível com as histórias da igreja e do império tomadas separadamente. Este argumento, apontado pelo historiador como bastante óbvio no presente, teria sido,

\footnotetext{
${ }^{40}$ L.-S. Le Nain de Tillemont, Histoire des Empereurs et des autres princes qui ont regné durant les sex premiers siècles de l'Eglesia, Paris, 1690-1738.

${ }^{41}$ Originalmente publicado em Rivista Storica Italiana, S. 5, vol. I, 1936, fasc. 1, pp. 35-60; fasc. 2, pp. 19-48; republicado em A. Momigliano, Contributo alla storia degli studi classici, Roma: Edizioni di storia e letteratura, 1955, pp. 107-64.
} 
entretanto, ignorado pela historiografia moderna sobre o império, cujo início remontaria ao século XVII. Momigliano observa, no artigo de 1936, que mesmo as obras contemporâneas não lidavam com a relação entre império e igreja senão com grande dificuldade, e que se tratava de uma questão ausente naquela que considera a mais importante delas, a "História Econômica e Social do Império Romano” de Rostovzeff, publicada em $1926 .{ }^{42}$

Buscando identificar a origem do problema, Momigliano remonta à Idade Média, quando o império romano não era pensado como entidade independente, mas como idéia correlacionada à idéia de igreja. Santo Agostinho definira a relação entre civitas terrena e civitas dei - o império como organização temporal da humanidade, a igreja como organização espiritual, e por um longo período o império romano permaneceria desta forma, como uma idéia inclusa em uma esfera religiosa: Sacrum Romanum Imperium. O Renascimento não tocaria a questão: os Discorsi sopra la prima Deca di Tito Livio de Maquiavel oferecem um quadro independente de preocupações teológicas, mas que limita suas considerações ao período republicano da história romana, deixando intocado o período imperial.

Momigliano identifica a dissolução da afirmação teológica de interdependência entre império e Igreja apenas do final do século XVII, com a publicação das obras de Tillemont e Bossuet, cujas abordagens historiográficas tomavam, pela primeira vez, o império como entidade desvinculada da igreja. O advento de tais abordagens teria marcado, no entendimento do historiador italiano, o início da pesquisa moderna sobre o império romano, inaugurando uma profunda separação entre história do império e história da igreja. O interesse de Bossuet e Tillemont pela história do império era, entretanto, conseqüência de seu interesse pela história da igreja, de forma que não viam qualquer outro significado na história daquele senão a preparação para o surgimento desta. A separação entre império e Igreja fora possível em suas obras apenas em função de uma sutil distinção entre fatos que seguem uma ordem humana e fatos que seguem uma ordem divina- uma história sacra feita por Deus em contraposição a uma história profana feita pelos homens segundo critérios nos quais o controle divino é apenas extrínseco. A despeito da ausência de interferências diretas por parte da providência, o

\footnotetext{
${ }^{42}$ A. Momigliano, Contributo alla storia degli studi classici, Roma: Edizioni di storia e letteratura, 1955, p. 107.
} 
caráter providencial do desenvolvimento histórico era ainda pressuposto na obra de ambos os autores.

No texto da lição de Cambridge, Momigliano passa brevemente de Tillemont a Gibbon, suprimindo parte do contexto retratado no artigo de 1936, sobretudo aquilo que diz respeito ao pensamento iluminista de Montesquieu e Voltaire, cujas reflexões teriam sido, segundo o autor, ampliadas por Gibbon em uma grande história do declínio do império romano. De acordo com Momigliano, apenas tendo-se em mente que a consciência histórica comum do tempo de Gibbon admitia a história do império como preparação para a história da igreja, é que se pode compreender o grande feito do historiador inglês. Gibbon revisitou o quadro até então tradicional: o império romano não mais se caracterizava como uma preparação para um mundo melhor - o mundo cristão, mas o advento do cristianismo punha fim a uma era melhor - a era dos Antoninos. O autor de Decline and Fall, entretanto, não teria se preocupado em compreender seriamente o desenvolvimento do cristianismo, que aparece em sua obra como uma força externa que ameaçava o império. Momigliano percebe a igreja e o império atuando em Gibbon como forças extra-humanas lutando entre si, dando forma clássica ao que considera uma forma absurda de pesquisa: o historiador buscava a explicação para o declínio do império em causas externas, quando a única explicação possível para este declínio consistiria na própria história do império.

O século XIX herda o problema do império como o problema do declínio de Roma. A história de Gibbon, apesar de seus limites e faltas, permaneceria como obra fundamental sobre o tema. O progresso da historiografia deste século, entretanto, se estenderia para além da imensa quantidade de novos materiais recolhidos e do advento de novos e melhores métodos de tratamento das fontes. Momigliano elenca três pontos nos quais identifica tal progresso: 1) a obra e métodos dos juristas constituíram outra parte do butim herdado pelo século XIX; Mommsen não escrevera uma história do império, mas uma descrição da constituição imperial. Sua descoberta de que a constituição do primeiro império romano não era uma monarquia absoluta e de que havia uma diferença substancial entre o principado dos primeiros séculos e a autocracia do baixo império, teria posto abaixo a interpretação jurídica que derivava da Idade Média, abrindo o caminho para uma interpretação histórica livre de sobrevivências medievais; 2) o império deixara de ser estudado apenas de seu centro, a atenção se 
voltava para as províncias. Mommsen, mais uma vez, teria sido o precursor, seguido nesse aspecto por Rostovzeff e T. Frank; 3) o estudo do desenvolvimento da igreja passara das mãos dos teólogos às mãos dos historiadores, tornando-se livre de preocupações dogmáticas. Estes três pontos constituiriam, na visão de Momigliano, os principais desenvolvimentos alcançados pela historiografia do século XIX, os quais teriam, de acordo com o historiador, tornado possível a recente história do império romano apresentada na Cambridge Ancient History.

Diante deste quadro, Momigliano propõe uma resposta para a questão da ausência de uma história relevante do império romano no período de dois séculos que separa a história de Tillemont da Cambridge Ancient History:

La storia dell'impero fu estremamente lenta a svilupparsi perché l'impero romano divenne nel Medio Evo e rimase a lungo nei tempi moderni un'idea giuridica e teologica. Doveva volgersi in uno sviluppo storico. L'impero romano doveva essere riconosciuto come una civiltà che restava in una sottile relazione di opposizione e identità con la civiltà cristiana. Il Cristianesimo nacque nell'impero romano, si oppose all'impero romano, assorbì l'impero romano. Gibbon non riuscì a capire che la chiesa non distrusse l'impero perché la vita della chiesa divenne vita dell'impero. Mommsen non riuscì a capire che l'impero non era una costruzione giuridica. ${ }^{43}$

Esta resposta vinha acompanhada de um programa de pesquisa para o futuro, que em linhas gerais corresponde àquele contido no projeto de seu livro sobre paz e liberdade no mundo antigo:

Come suggerivamo, la risposta a questa questione è già un programma per ricerche future. Abbiamo vieppiù da costruire la storia dell'impero romano come storia di valori spirituali - pagani e cristiani - dei primi secoli della nostra era. La storia politica non può mai restare in disparte: ancora meno quando si tratta di un periodo in cui le questioni politiche sonno connesse chiaramente con un problema religioso. Dobbiamo spiegare come e perché uno stato cristiano abbia rimpiazzato uno stato pagano. Questo è il problema dell'impero romano. ${ }^{44}$

Ao problema, Momigliano somava a questão dos papéis da Grécia e da Judéia, que mais tarde, sobretudo a partir da década de 1970, se tornariam o foco de sua pesquisa histórica. Gustav Droysen tentara explicar o cristianismo como resultado do intercâmbio entre as civilizações oriental e grega durante o período que se estende de Alexandre a Augusto. Para Momigliano Grécia e Oriente não seriam suficientes: o império romano seria o contexto natural do cristianismo, de forma que tanto o

\footnotetext{
${ }^{43}$ A. Momigliano, Pace e libertà nel mondo antico - Lezioni a Cambridge: gennaio-marzo 1940, Firenze: La Nuova Italia Editrice, 1996, p. 12.

${ }^{44}$ Ibidem, pp.12-13.
} 
cristianismo quanto o império só poderiam ser compreendidos se considerados conjuntamente. A importância da Grécia e de Jerusalém, por outro lado, não poderia ser subestimada: seus papéis teriam sido decisivos no contexto da história do império romano, de forma que constituem pontos fundamentais para o estudo deste.

\section{VI}

A primeira tarefa para a execução do programa proposto por Momigliano na primeira de suas leituras a Cambridge seria, de acordo com o autor, compreender a força que conduzira Roma da república ao principado. Nisto consiste justamente o tema de sua segunda lição, Che cos'è la crisi della republica. Duas obras, Vom Wesen des römischen Prinzipats de A. von Premerstein e The Roman Revolution de Ronald Syme, publicadas em 1938 e 1939 respectivamente, juntamente com a Cambridge Ancient History, são apontadas como as obras recentes mais relevantes a respeito do tema. A tendência da última seria, ainda que de forma pouco clara, tomar a passagem da república para o império como uma crise de todo o mundo mediterrâneo, ao passo que as duas primeiras tomariam esta passagem como uma crise circunscrita à classe dirigente romano-itálica. A escolha entre um ou outro destes pontos de vista era considerada relevante para Momigliano, pois significava estabelecer, na ótica do historiador, se o império romano representava um problema de governo relativo ao contexto romano apenas ou uma nova forma de sociedade humana. Tal questão é proposta como ponto de partida para a discussão que se segue.

Momigliano percebe a inclinação da pesquisa moderna a atribuir grande importância à relação entre patronato e clientela na vida política romana. A identificação primitiva da clientela com a plebe, por Mommsen proposta, é por ele descartada: a conjectura proposta pelo jurista alemão remeteria à história romana arcaica, ou seja, a pré-história sem documentos, ao passo que a questão a ser discutida é relativa aos últimos séculos da república e ao advento do império. O segundo estudioso citado no contexto da exposição de Momigliano era Fustel de Coulanges, que com sua Histoire des Instituions Politiques de l'ancienne France, publicada em 1890, fora o primeiro a por em relevo a importância da instituição da clientela na história romana tardia, sendo útil para se compreender como, na Gália, a clientela romana se sobrepõe às 
formas preexistentes de relações sociais. Uma definição clara da função da clientela no contexto da história republicana, entretanto, viria apenas com o livro de M. Gelzer de 1912, intitulado Die Nobilität in der romanischen Republik. As conclusões apresentadas por Gelzer nesta obra teriam sido reforçadas e desenvolvidas por outro importante estudioso, Friedrich Münzer, responsável por um sumário publicado na enciclopédia Pauly-Wissowa, ${ }^{45}$ no qual laços familiares, clientelas e alianças entre grupos rivais da aristocracia romana eram cuidadosamente analisados um a um, em ordem alfabética. Münzer fora também autor do livro Römische Adelparteien und Adelsfamilien (1920), no qual a república romana era retratada sob o domínio de um pequeno numero de abastadas famílias romanas com suas próprias clientelas.

Delineado este contexto, Momigliano passa enfim às obras recentes sobre o tema, iniciando pelo livro de von Premerstein, publicado postumamente em 1938. Premerstein descrevera a crescente importância do patronato no último século da república, concluindo que o imperador era essencialmente o patrono de uma enorme clientela que fora capaz de eliminar os demais patronos ou reduzir-los a seus clientes. Momigliano chama atenção para o caráter predominantemente jurídico e sociológico da obra de Premerstein, cujo objetivo era mostrar como as formas sociais e jurídicas da clientela teriam passado para a primeira constituição imperial. Constituía, dessa forma, um estudo de forma. O livro The Roman Revolution de Ronald Syme, por outro lado, aspirava ser um estudo de substância.

A discussão sobre a passagem da república ao império proposta na lição de Cambridge é em sua maior parte restrita à discussão do livro de Syme. Em 1962, ao escrever a introdução para a primeira edição italiana da obra, ${ }^{46}$ Momigliano relembrava o contexto em que a teria lido pela primeira vez, mais de duas décadas antes, em 1939,

\footnotetext{
45 Pauly-Wissowa, como é comumente chamada a Realencyclopädie der classischen Altertumswissenschaft, enciclopédia alemã de estudos clássicos cujo primeiro volume teve sua publicação em 1839 por August Pauly. Com a morte de Pauly em 1945, Christian Waltz e Wilhelm Teuffel davam continuidade ao trabalho, completo em 1852. Quase quatro décadas depois, em 1890, Georg Wissowa inicia o projeto de uma nova e mais ambiciosa edição, que esperava completar em um período de dez anos. O último dos 84 volumes, entretanto, não seria publicado antes de 1978, seguido do volume contendo um índice geral, publicado em 1980. A contribuição de Münzer para a enciclopédia ocorre a partir de 1893, ano em que fora recrutado por Georg Wissowa para a escrita de verbetes biográficos.

${ }^{46}$ Originalmente publicado em Ronald Syme, La rivoluzione romana, trad. Di M. Manfredi, Turin: Einaudi, 1962, pp. ix-xv; republicado em A. Momigliano, Terzo contributo alla storia degli studi classici, Roma: Edizioni di storia e letteratura, 1966, pp. 729-737 e A. Momigliano, A. D. Momigliano, Studies on Modern Scholarship, Berkley: University of California Press, 1994, pp. 72-79.
} 
ano da publicação da primeira edição de The Roman Revolution, ocorrida cerca de um mês antes da eclosão da segunda guerra mundial. Era também o ano em que historiador italiano chegara a Oxford em exílio. Neste contexto, a onipresença dos dramáticos eventos contemporâneos nas linhas oferecidas por Syme sobre a "revolução" de Augusto teriam tornado marcante a leitura de sua obra:

Syme's Roman Revolution appeared in the summer of 1939. I remember reading the copy given to me by the author at a time when war had already been declared and the nights were getting longer in an Oxford plunged in gloom. The book was gripping to read: it established an immediate rapport between the ancient March on Rome and its modern counterpart, between Augustus' seizure of power and Mussolini's coup d'état and perhaps Hitler's as well. The incisive vividness with which it represented the men and events of ancient Rome was a reflection of the experience of the times through which we were living. The effect was never contrived: the ancient texts spoke directly. It was also obvious that an author who wrote like this achieved clarity of vision through a personal act of liberation. ${ }^{47}$

Apesar de separados por um período de mais de vinte anos, o juízo sobre a obra de Syme oferecido por Momigliano em sua introdução de 1962 não diferia significativamente daquele de sua resenha da obra, publicada em 1940 - sua primeira publicação em um periódico britânico após sua chegada em Oxford. A resenha de The Roman Revolution de 1940 oferecia, por sua vez, a base para a discussão sobre a passagem da república ao império proposta na lição sobre o tema apresentada em Cambridge naquele mesmo ano. Na realidade, o texto da lição consiste, em grande medida, em uma transcrição exata do texto da resenha da obra de Syme.

Havia, já na época de sua publicação, a consciência de que o livro de Syme constituía uma obra revolucionária sobre o principado de Augusto, de forma que The Roman Revolution surgia já como um clássico: M. Ginzburg (outubro, 1940) o considera "talvez o mais importante [livro] desde a publicação do monumental trabalho de Rostovzeff”; ${ }^{48}$ A. F. Giles (março, 1940) afirma ser ele, "de fato, um dos mais importantes livros de história romana desde Mommsen”; ${ }^{49}$ para R. L. D. (fevereiro, 1940), o estudo de The Roman Revolution constituiria "um dos mais importantes trabalhos sobre a história romana desde a História Econômica e Social de Rostovzeff”. ${ }^{50}$

\footnotetext{
47 A. Momigliano, "Introduction to R. Syme, The Roman Revolition,” in A. D. Momigliano, Studies on Modern Scholarship, Berkley: University of California Press, 1994, p. 72.

${ }^{48}$ The American Historical Review, Vol. 46, No. 1 (Oct., 1940), pp. 106-108.

${ }^{49}$ The Classical Review, Vol. 54, No. 1 (Mar., 1940), pp. 38-41.

${ }^{50}$ Greece \& Rome, Vol. 9, No. 26 (Feb., 1940), pp. 123-126.
} 
O próprio Momigliano (1940), por fim, o descreveu como "o melhor livro desde a grande obra E. Meyer, à qual é antitético.”51 Em sua resenha, o historiador italiano afirmava que o livro de Syme necessitaria mais consideração do que aquelas que oferecia então, poucas semanas após seu aparecimento. Assim, além de um quadro - em grande medida pessoal - do contexto em que The Roman Revolution aparecera, Momigliano fornecia, na sua introdução de 1962, um levantamento de uma série de críticas ao estudo de Syme, emergidas em função de novas evidências surgidas no período de duas décadas que se seguira à publicação da obra, além de uma análise do impacto desta na produção histórica subseqüente. Syme garantira, de acordo com Momigliano, a vitória de uma tendência historiográfica que interpreta a política de Augusto não em termos constitucionais ou ideológicos, mas em termos de clientelas e famílias aristocráticas rivais. Sua interpretação podia ser contestada em matéria de detalhes, mas não ignorada: fora responsável pela introdução de uma nova forma de se olhar o principado de Augusto. Nos vinte anos que se seguiram a The Roman Revolution, Momigliano aponta a publicação de apenas uma obra que julgara importante sobre o tema - Il tempo di Augusto, de M. A. Levi, a qual, sobretudo em função do contexto de seu surgimento, em 1951, não fora capaz de levantar discussão.

Uma das qualidades distintivas da obra de Syme apontada por Momigliano consistia na rejeitação por parte do autor daquilo que reconhecia como uma interpretação partidária e pragmática da historiografia que, segundo ele, admirava Augusto simplesmente pelo êxito que obtivera. Incorporando-se à tradição de Salústio, Tácito e Pólio, historiadores de sentimentos republicanos cuja influência é evidente e francamente admitida em sua obra, Syme rompe com o quadro comum então na Inglaterra, no qual uma imagem positiva do governo de Augusto era oferecida -

it was enough to have read the chapters on Augustus in the Cambridge Ancient History, which had appeared in 1934, to realize that in England the usual assessment of the government of Augustus was, by contrast, one of sympathy and assent. English scholars (...) pushed this consensus to the point of accepting the 'noble lies' of ideological propaganda as both inevitable and useful. Syme style, which consciously took up themes and language of Tacitus (...) was the outward sign of the break with the academic conventions adopted by his colleagues at Oxford and elsewhere. $^{52}$

\footnotetext{
51 Journal of Roman Studies, 30, 1940, pp. 75-80, republicado em A. Momigliano, Secondo contributo alla storia degli studi classici, Roma: Edizioni di storia e letteratura, 1984, pp. 407-416.

52 A. Momigliano, "Introduction to R. Syme, The Roman Revolition,” in A. D. Momigliano, Studies on Modern Scholarship, Berkley: University of California Press, 1994, p. 72.
} 
Ecos desta convenção aparecem na resenha de W. L. Wannemacher, que aponta para a luz “excessivamente desfavorável” com que Syme retrata o caráter, personalidade e motivos de Augusto - ainda que considerasse estimulante e intelectualmente provocativo, o resenhista expressava dúvidas quanto à completa adesão de muitos historiadores à delineação oferecida pelo autor, a qual considerava "extremamente reacionária”. 53

Tanto quanto as suas virtudes, as faltas do livro de Syme eram percebidas e apontadas com igual ênfase já na época de seu aparecimento. O método do historiador era sobretudo prosopográfico, seguindo, como visto, o caminho trilhado anteriormente por Gelzer e Münzer, e a abordagem predominantemente prosopográfica de sua obra apresentava limitações que ofereceram margem à crítica. Dessa forma, D. McFayden elogia Syme por haver inquestionavelmente adicionado ao entendimento da política romana através de seus estudos prosopográficos, pondo em dúvida, porém, o valor dos resultados por ele obtidos, afirmando que o historiador teria ido longe demais ao reduzir toda a história da república a uma série de clãs rivais: ambições individuais e filiações familiares poderiam, de acordo com McFayden, haver contribuído para determinar o lado que um político tomara em uma determinada contenda, mas o curso dos eventos seria determinado não por alianças e conflitos entre indivíduos, mas por causas fundamentais como a ineficiência do governo oligárquico, a ascensão do exército profissional, a natureza não-representativa da comitia e outras forças que estudos anteriores tão bem estabeleceram. ${ }^{54}$ Para A. D. Windspear, a abordagem de Syme obscureceria as bases social, econômica e política, bastante reais para o conflito do I século a.C., reduzindo a totalidade da disputa entre populares e optimates a questões puramente pessoais. ${ }^{55}$ Em sua resenha, Momigliano apontava o problema nos seguintes termos:

(...) prosopographical research cannot give a sufficient interpretation of this period (and, we would add, of any historical period. Prosopographical research has the great virtue of reaching individuals or small groups, but does not explain their material or spiritual needs: it simply presupposes them. History is the history of problems, not of individuals or groups. If the tacit assumption of much prosopographical research is that people are moved by personal or family

\footnotetext{
53 The Classical Weekly, Vol. 34, No. 2 (Oct. 14, 1940), pp. 18-19.

54 The Classical Journal, Vol. 38, No. 1 (Oct., 1942), pp. 38-40.

${ }^{55}$ American Sociological Review, Vol. 6, No. 1 (Feb., 1941), pp. 123-125.
} 
ambition, the assumption is not merely one-sided; it substitutes generic trends for concrete situations. Further, in our special case, given the nature of the documents available for Roman history in the first century B.C., prosopographical research is bound to be restricted to the leading men, and they may be less significant than the masses. S.'s book is lacking background. No clear description is given to the situation of the Roman State before the revolution. ${ }^{56}$

O argumento é repetido no texto da leitura de Cambridge com o conteúdo ligeiramente diferente. A afirmação da necessidade de se compreender as necessidades tanto materiais quanto espirituais dos indivíduos é mantida, ao passo que a interdependência entre indivíduos e massa é estressada com maior ênfase:

La ricerca prosopografica ha la grande virtù di trattare, per quanto possibile, di individui o piccoli gruppi, ma no spiega i loro bisogni materiali o spirituali : semplicemente li presuppone. Storia è storia dei problemi, non di individui o di gruppi. Se il tacito presupposto di molte ricerche prosopogragrafiche è che la gente è mossa da ambizioni personali o familiari, il presupposto non è solo unilaterale ma scambia generiche tendenze per situazione concrete. Ogni ambizione è possibile solo in una situazione storica. Gli interessi personali o familiari di ogni uomo dipendono direttamente o indirettamente dalla situazione di migliaia di altri uomini. Questo argomento, per quanto banale, è sufficiente a mostrare come è assurdo pensare che negli ultimi secoli della repubblica la storia di Roma potesse essere nelle mani di alcune centinaia di dominanti. Nelle loro mani c'era il potere politico ma non la storia, che è un'altra cosa. Inoltre, è giusto ammettere che gli uomini hanno impulsi migliori o peggiori di quello di difendere la propria posizione personale o familiare. ${ }^{57}$

O recorte de Syme, que se inicia em 60 a.C. e se estende a 14 d.C., é contestado por Momigliano, que considera a primeira data inapropriada para o início de uma história da revolução romana. Ainda que Ulrich Kahrstedt estivesse equivocado ao propor, em seu livro Grundlagen und Voraussetzungen der römischen Revolution (1927), a idéia de uma revolução romana como reação a um movimento social vermelho que atravessava o império, os eventos anteriores a 60 a.C. por ele apontados - a aventura de Sertório, o putsch de Lépido, a rebelião de Espartaco, a pirataria e a guerra mitridática - eram autênticos e, de acordo com Momigliano, davam a medida das dificuldades então iminentes. Ao decênio de 80 a 70 a.C., marcado por rebeliões e repressões, seguiram-se duas décadas de conquistas, no contexto das quais líderes militares teriam preservado o poder às custas do senado, ao passo que as classes ricas da Itália e das províncias vislumbravam, após da ditadura de Sila, um novo futuro na

${ }^{56}$ A. Momigliano, Secondo contributo alla storia degli studi classici, Roma: Edizioni di storia e letteratura, 1984, p. 411.

${ }^{57}$ A. Momigliano, Pace e libertà nel mondo antico - Lezioni a Cambridge: gennaio-marzo 1940, Firenze: La Nuova Italia Editrice, 1996, p. 20. 
clientela dos generais. Momigliano identifica a ocorrência da revolução no momento em que cessam as conquistas em função das derrotas militares, da reação senatorial e das rivalidades entre líderes. O movimento de César visando conservar vantagens para seus soldados e o poder para si provocara inquietação na Itália e nas províncias. Havia naquele momento mais em jogo que posições privilegiadas em países distantes: a própria Roma tornara-se o alvo da conquista. Este contexto, óbvio na consideração de Momigliano, era ignorado não apenas por Syme, que reduzira a revolução romana a uma luta entre facções, mas fazia-se ausente nas obras daqueles que considerava os melhores estudiosos de sua geração. Diante disso, Momigliano reiterava, acima de outros fatores já apontados pela historiografia anterior, a importância do exército para o contexto da revolução: “a monarquia romana é um produto não de homens sobre quem é possível escrever artigos na [enciclopédia] Pauly-Wissowa, "mas de pessoas obscuras, tanto italianos quanto provinciais, cujo nome é legião". ${ }^{88}$ As legiões representavam, para o historiador, uma classe social desprovida de poder político e que não podia sequer imaginar um modo de obtê-lo diretamente, mas que estaria economicamente e espiritualmente preparada para oferecer ajuda a qualquer tentativa de se destruir o governo senatorial.

De acordo com Momigliano, Syme teria se aproximado de um quadro verdadeiro ao propor que o principado não significava apenas a vitória de Augusto e sua facção, mas a vitória das classes apolíticas do império. Pois o principado teria significado também a vitória da Itália sobre Romauma Itália que já pouco se distinguia do povo romano como parte dominante do império, mas que em comum com as províncias era desprovida de poderes políticos reais pela inexistência de um sistema representativo. Com a revolução, a vida municipal italiana se tornava o padrão para a vida provincial sob o império, de forma que a Itália apolítica oferecia o modelo para a orbis romana apolítica. Diante deste quadro, Momigliano expressa sua discordância em relação à conclusão de Syme quando este propõe que o povo romano abrira mão de sua liberdade política em troca da paz e da ordem que o governo senatorial não mais podia oferecer. Na sua interpretação, teriam sido os líderes do extrato apolítico do império que, vitoriosos com a revolução, teriam privado o povo romano de sua liberdade

${ }^{58}$ A. Momigliano, Secondo contributo alla storia degli studi classici, Roma: Edizioni di storia e letteratura, 1984, p. 407. 
política. O texto da leitura de Cambridge repete o argumento do texto da resenha de The

Roman Revolution exatamente nos mesmos termos, o qual segue:

Mr. Syme gives perhaps his final judgment in the statement that 'there is something more important than political liberty; and political rights are a means not an end in themselves. That end is security of life and prosperity: it could not be guaranteed by the constitution of the Republican Rome. Worn and broken by civil war and disorder, the Roman People was ready to surrender the ruinous privilege of freedom, and submit to strict government' (p.513). In our opinion, the truth is different. If we take the whole movement 80-27 B.C., it may scarcely be doubted that in the Roman Revolution leaders of a majority, who had no political rights, dispossessed the senatorial class and the Roman People as a voting class. The Italians, who had obtained the Roman franchise, were destitute of real rights for lack of a representative system. The Romans lost their freedom because they had not shared it. They did not surrender their freedom for their own advantage: they were deprived of it. The triumph of clientship, as S. and v. Premerstein have so fundamentally analysed, completely confirms the fact that people who have not sufficient political rights become the prey of political agitators. Clientship is not an explanation, it is a manifestation - manifestation of an immense movement of people, who preferred to the freedom of the others a government which promised and gave them peace, tolerable justice, an increasing amount of political equality, and fair prospects of a career. The monarch was, inevitably, monarch of everybody. If one considers the Augustean State as the simple result of a triumph of a party, one will never understand that for twelve or thirteen centuries, if not more, that State was the only conceivable State. ${ }^{59}$

Diante deste argumento, Momigliano concluía a resenha do livro de Syme sublinhando a necessidade de um estudo da revolução romana que contemplasse a passagem da libertas republicana à pax augusta, paralelo à qual identificava a um desenvolvimento da concepção romana de liberdade: a passagem da libertas republicana para uma libertas que reconhecia como mais profunda por estabelecer uma relação entre liberdade política e dignidade humana - a libertas de Bruto e de outros opositores do império. O trecho que segue é comum ao texto da resenha e ao texto da lição de Cambridge, aparecendo como o parágrafo conclusivo no contexto de ambos:

\begin{abstract}
I have no intention of belittling the loss to mankind of the decline of Roman freedom. It took some twelve centuries of Western civilization to reconquer in the Italian comuni the principles of Roman Republican government; and not perhaps before Machiavelli do we find again the political experience based on the Roman Republic. The Roman libertas has a permanent value. (...) We must distinguish the serious experience of political responsibility, which characterized the Roman Republican constitution, from the consciousness of human dignity inherent in political freedom as discovered by those men who lived at the end of
\end{abstract}

\footnotetext{
59 A. Momigliano, Secondo contributo alla storia degli studi classici, Roma: Edizioni di storia e letteratura, 1984, p. 415. O argumento é proposto nos mesmos termos, mas com seu texto condensado e traduzido para o italiano, em A. Momigliano, Pace e libertà nel mondo antico - Lezioni a Cambridge: gennaio-marzo 1940, Firenze: La Nuova Italia Editrice, 1996, p. 27.
} 
the Republic or in the struggles of the Senatorial and Stoic opposition against the triumphant monarchy. We may say that the second gift of the Roman Empire, in addition to its universality, is the knowledge a contrario that despotism imposes moral degradation upon man. The libertas which educated modern Europe comes from Brutus’ letters, Lucan, Tacitus, Plutarch: ${ }^{60}$

A partir deste ponto, Momigliano oferece um desfecho diferente para cada um dos textos. A conclusão para a resenha sublinhava a necessidade de um estudo da revolução romana nos seguintes termos:

(...) it derives, but must be differentiated, from the Greek eleutheria and the Roman Republican libertas. It is the task of a complete study of the Roman Revolution to describe this passage from the Republican libertas to the Pax Augusta and the opposition to the Pax Augusta in the name of a more profound, but still aristocratic, libertas. ${ }^{61}$

A lição de Cambridge, por sua vez, era concluída com a proposta de uma tarefa similar, mas que se estendia para além do contexto da revolução romana, em uma evolução das idéias de liberdade e paz - nas formas de libertas e pax augusta - que convergia para o advento do cristianismo:

(...) deriva della libertas repubblicana ma deve essere differenziata da essa. La libertas repubblicana provocò come reazione il movimento delle classi apolitiche dell'impero in direzione di una maggiore giustizia, una maggiore eguaglianza, una maggiore sicurezza. Il movimento, dopo tante guerre civili, ricevvete la sua espressione classicca nella pax augusta. Contro questa anche se ancora troppo aristocratica e debole, la libertà di Brutu. Pax e libertas divennero i due elementi fondamentali della vita spirituale dell'impero, contrastanti tra loro senza mai scomparire. Il Cristianesimo li raccolse. Seguiremo l'evoluzione di questi ideali. $^{62}$

Desta forma, Momigliano introduzia os temas da paz e liberdade no contexto de suas lições de Cambridge, em torno dos quais seriam desenvolvidas as lições subseqüentes.

\section{VII}

A lição intitulada Paz se inicia com a retomada da discussão sobre o exército, apresentada ainda nos termos do texto da resenha de The Roman Revolution. O primeiro

\footnotetext{
${ }^{60}$ A. Momigliano, Secondo contributo, 1984, p. 415-16; em tradução italiana: A. Momigliano, Pace e libertà nel mondo antico, 1996, p. 27-28.

${ }^{61}$ A. Momigliano, Secondo contributo, 1984, p. 416.

${ }^{62}$ A. Momigliano, Pace e libertà nel mondo antico, 1996, p. 28.
} 
ponto da discussão consiste na relação entre exército e pax augusta. A universalidade do império romano é proposta, no contexto desta discussão, como produto de convicção e fundação administrativa- em outras palavras, pax e exército. A relação entre uma e outro não constituía, segundo Momigliano, uma contradição: era o exército que, contendo os ânimos da aristocracia, possibilitava a manutenção da paz dentro dos limites do império. O segundo ponto é relativo ao papel do exército de Augusto na romanização das províncias, com destaque para a qualidade de multiplicador do homem apolítico que era a este exército inerente. Se, como teria proposto Syme e sublinhado Momigliano, o principado de Augusto havia significado a vitória das classes apolíticas do império, seu exército encarnava o ideal de homem alheio à vida pública: recrutado entre as massas apolíticas, o soldado apolítico era delas um produto e a elas retornava em posição preeminente após o serviço militar, reforçando o caráter apolítico de seu meio e completando assim o círculo. ${ }^{63}$

A paz teria constituído o ideal da classe governante e um problema capital do governo imperial. A fim de compreender a eficácia deste ideal, Momigliano propõe traçar seu lento desenvolvimento, no qual operariam, conjuntamente com a influência oriental, as concepções grega e romana. O desenvolvimento desta proposta no contexto das lições de Cambridge aparece em parte em uma tradução literal, em parte em uma extensão da discussão sobre paz no mundo antigo por Momigliano apresentada em sua leitura inaugural Koiné Eirene, Pax Romana, Pax Christiana, de 1936. O historiador retraça, nos mesmos termos de seu texto de 1936, aqui já anteriormente delineados, a evolução do conceito helênico de paz do início do IV século a.C. ao domínio persa - do spondai ao advento do ideal de koiné eirene, analisando como este ideal haveria se tornado um instrumento dos domínios persa e posteriormente romano, da mesma forma que fizera no texto da leitura inaugural. O texto da lição de 1940 oferece, entretanto, um quadro mais detalhado das conseqüências desta evolução do ideal de paz helênico no quadro da história romana.

Momigliano observa que a política de Flaminino, que reafirmava o ideal da koiné eirene proclamando em 196 a.C. a liberação das cidades gregas, teria logo sido abandonada. O governo senatorial pouco se preocupava com justificações ideológicas

${ }^{63}$ Este ponto era também discutido no artigo intitulado "L'esercito di Augusto e la romanizzazione dell’Oriente”, de 1938, publicado em A. Momigliano, Nono contributo, 1992, pp. 445-455. 
nas províncias, que eram arruinadas pela violência e pela ganância. Ao passo que a paz como eirene perdia terreno, a paz como homonoia tornava-se um problema fundamental para a vida política romana, o que Momigliano ilustra com a introdução do culto helênico de Homonoia-Concordia em Roma no decorrer da segunda guerra púnica. Com a revolução de Augusto, entretanto, um movimento inverso é pelo historiador apontado: o ideal de paz como concórdia interna é abandonado por um novo ideal de paz como eirene - a paz como ordem geral do mundo, a qual se torna pax romana. Já indicando a unicidade da abordagem dos temas paz e liberdade, Momigliano oferece na lição seguinte uma análise da pax romana, a qual aparece sob o título "Liberdade dos Antigos”.

A despeito das influências helênicas e orientais, que Momigliano discute apenas brevemente, a pax augusta permanecia, segundo o historiador, romana em sua essência. Tornara-se uma idéia política, uma regulação permanente que derivava da vitória: dare legis. Esta discussão, assim como aquela proposta na lição anterior, é ordenada da mesma forma e apresentada nos mesmos termos do texto da leitura inaugural de Torino, consistindo em grande medida em uma tradução literal do mesmo. Em um ponto específico, entretanto, os juízos oferecidos por Momigliano em um dos textos se contrapõem àqueles oferecidos no outro. A conclusão do historiador para a sessão sobre a pax augusta no contexto da leitura inaugural de 1936 era proposta nos seguintes termos:

E quando già i Goti premeranno alle porte di Roma, Claudiano troverà nella missione di paci di Roma la fiducia nella sua perenità: 'Questa è colei che sola accolse i vinti in grembo e con comune nome crebbe l'umana gente con rito di madre, non di padrona; e chiamò cittadini quelli che domò e congiunse con pio legame le legionei lontane. Ai suoi costumi di pace dobbiamo tutti... di essere tutti una gente sola. Né mai sarà termine all'impero di Roma'. ${ }^{64}$

Já no texto da lição de Cambridge, Momigliano escolhia um trecho diverso para a citação de Claudiano:

When the Barbarians were at the Gates of Rome, the voice of Claudian justified his faith in the eternity of Rome by Rome's mission of peace. Compare De Consulatu Stilichonis, book three, line one fifty four: 'we all owe it to Rome's peaceful ways - pacificis moribus - that the stranger treats other provinces as

\footnotetext{
${ }^{64}$ A. Momigliano, Nono contributo alla storia degli studi classici e del mondo antico, Roma: Edizioni di storia e letteratura, 1992, p. 421.
} 
his homeland, that one may change one's country of residence; that to visit Thule and to reach remote parts, which once inspired terror, is now sport' ${ }^{65}$

O trecho a seguir, que se segue à citação de Claudiano no texto da lição de Cambridge, é ausente no texto da leitura de 1930:

The Pax Romana we have described was not only an ideal. It was a fact. It was certainly an amazing experiment in resolving the political problem of mankind. It suppressed immemorial feuds among races and nations. It assured a comparatively unified economic life. It fostered gentle sentiments in the daily life. It introduced higher standards of life, especially in the West. Gaul, Spain, Britain and the Danubian countries received their foundations through the pax romana. Two languages became sufficient for the whole Mediterranean world, the language of Homer and Plato and that of Vergil and of the Twelve Tables. The codification of private law became a definition of the individual sphere and assured, even in the worst times, a certain independence of a man towards the state. The Roman state never lost the consciousness that the authority of the state has its limits.

Yet, none of us will conceal a profound sense of dissatisfaction in contempling the peace of the Roman Empire, even $\mathrm{n}$ its best times. The pax romana imposed a slavish obedience on the members of the Roman state and gave free hand to the ruling class in dealing with the poor. Peace may be either life or death. Roman peace was close to death. For the aim of this peace was peace - calm at the borders of the Empire and calm within the borders. It is a nonsensical problem to ask whether this form of deathly peace was a result of the imperial government or a product of the moral indifference of the subjects. Where in such forms of state compulsion ends and consent begins nobody can ever say. Spiritual life was as superficial in the court of Rome as in the palaces and manors of the landlords in the provinces. Trajan is the optimus princeps. Pliny the younger was humanissimus. Yet, his Panegyric - a broad picture of the pax romana in action - is void of every element of serious moral life: it is ineffectual and dry, sincerely dry. People are good and gentle, but superficial. The crisis at the end of the second century A.D. deprived the rich of the pleasure of being generous and of being honoured as generous: it destroyed the strongest tie of human solidarity existing at that time. The economic crisis disclosed the internal deficiency of this world. This is the meaning of the so-called crisis of the third century. ${ }^{66}$

Em contraste com o juízo oferecido na conclusão que se segue à citação de Claudiano no texto de sua leitura inaugural, no qual propunha que "la pax romana risolveva il problema politico della convivenza degli uomin; non risolveva il problema religioso della esistenza degli uomini," 67 o historiador afirmava na conclusão do texto

\footnotetext{
${ }^{65}$ A. Momigliano, Pace e libertà nel mondo antico, 1996, p. xxiii.

${ }^{66}$ Ibidem, p. xxiii-xxiv.

${ }^{67}$ A. Momigliano, Nono contributo alla storia degli studi classici e del mondo antico, Roma: Edizioni di storia e letteratura, 1992, p. 423.
} 
da lição de Cambridge: “The pax romana did not resolve the political problem because it did not resolve the religious and moral problem." 68

Estas diferenças entre os textos de 1936 e de 1940 fornecem uma via para a compreensão da nota que em 1982 Momigliano deixava no texto da leitura inaugural. É provável que a insatisfação do historiador com o texto da leitura - percebido por Carlo Dionisotti como surpreendentemente íntegro e honesto em vista do contexto em que fora escrito - não fosse motivada por qualquer sentimento de vergonha da parte de seu autor, mas por ter havido este, em diferente contexto, retomado o problema, propondo-o com diferente conclusão. A reformulação do texto da leitura em 1940 e o conteúdo da nota de 1982, “da pubblicarsi solo con avvertenza sulla situazione politica e personale di chi ebreo e non fascista si trovava a parlare,” permitem deduzir, tal como propõe Di Donato, que a insatisfação de Momigliano com o texto de 1936 ocorresse em função daquilo que, no contexto proibitivo daquele ano, o historiador teria pensado e deixado de escrever. É possível especular-se, do mesmo modo, se a forma como o historiador compreendia a questão tenha se modificado em face dos dramáticos eventos transcorridos entre a leitura inaugural de 1936 e leitura em Cambridge de 1940, tanto no âmbito político quanto no âmbito pessoal. Para tanto, uma análise mais cuidadosa da nota de 1982, sobretudo o que diz respeito à condição de "hebreu e não-fascista” para a qual Momigliano chamava a atenção, se faz necessária.

\section{VIII}

Nascido em 1909 em Caraglio, uma pequena cidade na região de Piemonte, no norte da Itália, Momigliano cresceu no contexto de uma tradicional família judaica, que mantinha, de acordo com o próprio historiador, uma estrita vida judaica ortodoxa. ${ }^{69} \mathrm{O}$ termo ortodoxo não teria neste contexto o mesmo significado de seu uso contemporâneo, como observou Joana Weinstein em seu artigo Where Three Civilizations Meet. ${ }^{70}$ “Ortodoxia” constituiria uma noção associada às controvérsias da reforma do judaísmo proposta na Alemanha no século XIX, de forma que o termo

\footnotetext{
${ }^{68}$ A. Momigliano, Pace e libertà nel mondo antico, 1996, p. xxv.

${ }^{69}$ A. Momigliano, Pagine ebraiche, Torino: ed. Silvia Berti, 1987, p. xxx.

${ }^{70}$ J. Weinstein, "Where Three Civilizations Meet”, in: History and Theory, Vol. 30, No. 4, pp. 13-26.
} 
tornou-se constrito aos limites daquela polêmica. A partir daquilo que descreve como um "quadro breve e fragmentário do meio judaico ao qual Momigliano pertencera", ${ }^{71}$ Weinstein propõe que a ortodoxia expressa no discurso do historiador emergiria como um firme e total compromisso com o judaísmo e com a identidade judaica, ao qual o Momigliano se manteria fiel no decorrer de toda sua vida. Este compromisso é aparente em um de seus últimos escritos, o prefácio à edição italiana do livro Use and Abuse of History de M. I. Finley, publicada logo após o falecimento deste em 1987, no qual Momigliano acusava o historiador americano de origem russo-hebraica - cujo verdadeiro nome, Finkelstein, fora mudado para Finley no início da década de 1940 de haver repudiado sua "excepcional hereditariedade rabínica”. ${ }^{72}$

O primeiro contato de Momigliano com a língua hebraica e com os textos da tradição judaica ocorreu durante sua infância através do avô paterno, Amadio, um perito nesta tradição. O pai de Momigliano, Riccardo, assim como seu primo, o notável socialista Felice Momigliano, tiveram um papel igualmente importante na formação do jovem Arnaldo. Temas relacionados à tradição judaica aparecem na obra do historiador logo no início de sua produção acadêmica: a uma tese sobre Tucídides, defendida em 1928 pelo então jovem estudante da faculdade de letras e filosofia da Universidade de Torino, seguia-se a publicação de um estudo sobre os Macabeus, intitulado Prime linee di storia della tradizione maccabaica. Proposto pelo autor como um trabalho preparatório para uma história dos Macabeus a ser escrita, projeto que nunca viria a ser concretizado, o estudo consistia em uma análise filológica e valorativa das fontes utilizadas pelos autores dos livros dos Macabeus. No contexto desta obra, a identidade judaica do historiador aparece entrelaçada com o tema de seu estudo, o que fica aparente sobretudo no pronunciamento de sua conclusão, no qual estabelecia uma relação de continuidade entre o estudo que oferecia e a tradição que constituía seu tema. Momigliano sublinhava ainda, no mesmo trecho, a importância dos âmbitos religioso e

\footnotetext{
${ }^{71}$ No que diz respeito a este quadro, Weinstein destaca as recorrentes contribuições de parentes próximos de Momigliano para o jornal judaico Il vessillo israelitico, publicado na região de Piemont entre os anos de 1874 e 1922. Dentre os familiares do historiador, destaca a atuação de um irmão do avô de Momigliano, que apontado como rabino da cidade de Bolonha em 1866, fora responsável pela revitalização da comunidade judaica na cidade, que havia sido expulsa em 1593 por um decreto papal e oficialmente restabelecida apenas em 1796.
}

${ }^{72}$ M. I. Finley, Problemi e metodi di storia antica, Bari: Laterza, 1987, pp. v-vi. 
moral, e a caracterização destes como força espiritual, conceitos que, como visto, retomaria mais tarde em sua história da paz e liberdade no mundo antigo:

(...) Si può quindi legittimamente concludere che la storia dei Maccabei, in quanto è storia di vita religiosa e morale, si continua nella storia della tradizione intorno di loro. Sempre del resto, come è ovvio, la storiografia non si sovrappone alla realtà, ma la continua. E anche noi, cercando di studiare criticamente la storia della tradizione maccabaica e rendendoci conto della forza spirituale, che essa ha costituito, prolunghiamo questa storia. ${ }^{73}$

Temas relacionados ao judaísmo aparecem apenas marginalmente nos estudos de Momigliano durante o período em Roma e os primeiros anos de exílio na Inglaterra. É principalmente a partir da década de 1970 que estes temas passariam a constituir uma parcela mais significativa da produção do historiador. A história judaica, entretanto, raramente aparecia isolada no contexto desta produção, mas em sua relação com as civilizações helênica e romana. O período helenístico, cujo conceito fora introduzido no século XIX pelo historiador alemão Gustav Droysen, constituía aqui o foco da abordagem do historiador.

Uma discussão a respeito da Geschichte des Hellenismus de Droysen era por Momigliano proposta em um artigo publicado em 1970, no qual alguns problemas inerentes à obra do historiador alemão eram apontados. Momigliano chamava atenção para a ambigüidade do termo helenismo, para o qual propunha uma definição cronológica (como um período que se estenderia de Alexandre Magno em 323 a.C. à morte de Cleópatra em 30 d.C.), no interior da qual se configuraria como um sistema político (que se desenvolvera em conseqüência das vitórias de Alexandre e de sua morte prematura e que teria no Egito seu mais importante sobrevivente, encontrando seu fim com a absorção do país ao império romano). Em contraposição à idéia de um mero sistema político, Momigliano propunha o helenismo como uma civilização, definição que julgava mais apropriada e que não poderia ser confinada a recortes cronológicos e espaciais, se estendendo inclusive para além dos territórios e culturas que fizeram parte do império de Alexandre. De acordo com o historiador, na raiz desta ambigüidade terminológica estariam as ambigüidades inerentes à própria obra de Droysen, que introduzira o termo helenismo para designar a civilização do mundo de língua grega

\footnotetext{
${ }^{73}$ A. Momigliano, Prime linee di storia della tradizione maccabaica, Torino: Casa Editrice Giovanne Chiantore, 1931, p. 172.
} 
posterior a Alexandre sem haver, no entanto, definido com clareza os limites de sua abordagem.

As duas definições propostas por Momigliano apontam para o que identifica como dois aspectos distintos do helenismo, sendo 1) um movimento cultural que produzira uma nova síntese de idéias gregas e orientais, e 2) um desenvolvimento político que resultou na constituição de um sistema de Estados no qual nativos orientais eram governados por uma aristocracia Greco-macedônia. Momigliano identifica na obra de Droysen um problema na relação entre estes dois aspectos, propondo que o historiador alemão possivelmente nunca estivera completamente ciente da distinção entre eles. Visando escrever uma história da transição do paganismo ao cristianismo, Droysen propunha um programa que previa uma abordagem dos desenvolvimentos culturais e religiosos decorridos no período de seu recorte. Momigliano chama a atenção para a ausência desta abordagem na obra do historiador alemão, sublinhando que sua história do helenismo se limita exclusivamente a um exame da história política do período entre 323 e 221 a.C. Dos dois aspectos do helenismo observados por Momigliano, Droysen teria negligenciado justamente aquele mais significativo para a compreensão do advento do cristianismo que buscava.

A razão para este paradoxo é por Momigliano identificada na relação de Droysen com o judaísmo. O conhecimento do historiador alemão a respeito do tema era, de acordo com Momigliano, limitado. O que sabia, entretanto, teria sido suficiente para estar convencido de que o cristianismo estava mais próximo do paganismo grego que do judaísmo, de forma que em sua abordagem, Droysen enfatizava o encontro de gregos e demais povos orientais, excluindo os judeus. Uma série de novos estudos relacionados ao tema surgidos no contexto da década de 1830, entretanto, teriam levado Droysen a reconsiderar, no final daquela década, esta sua posição. ${ }^{74}$ Entre os indícios de que passara a nutrir um maior interesse pelo judaísmo, Momigliano aponta para a inclusão de livros judaicos na literatura popular helenística que pretendia estudar e a primeira menção ao judaísmo como um elemento importante para a origem do cristianismo no

\footnotetext{
74 Entre as quais Momigliano destaca A. Dähne, Philo und die alexandrinische Theosophie (1831); Geschichtiche Darstellung der jüdisch-alexandrinischen Religionphilosophie (1834); A. Neander, Genetische Entwickelung der vornehmsten gnostischen Systeme (1818), cuja tese foi desenvolvida por F. Chr. Baur, Die christiche Gnosis (1833); Baur, Apollonius von Tyana und Christus (1832)
} 
contexto do último capítulo do segundo volume de sua Geschichte des Hellenismus, publicado em 1943.

A partir deste ponto, entretanto, Droysen não levaria adiante seus estudos relacionados à Antigüidade. Apontado como professor na universidade de Kiel em 1940, o historiador interrompia neste período a produção de sua história do helenismo, passando a se dedicar à história moderna, sobretudo à história da Prússia. O gosto de Droysen pela arte e literatura clássicas e seu aparente desinteresse pela cultura helenística, assim como sua crescente desconfiança em relação aos métodos de Hegel, que eventualmente levavam a conclusões por ele tidas como blasfemas, ${ }^{75}$ são apontados como possíveis razões pelas quais Droysen interrompera seus estudos sobre o período helenístico. Em uma nota Momigliano fazia alusão ainda ao declínio da importância da história antiga nas universidades alemãs a partir da década de 1840, observado por J. Engel em Historische Zeitschrift (1959). Um motivo diverso, entretanto, é por Momigliano destacado. Como jovem estudante e professor em Berlin, Droysen estabelecera amizade com indivíduos ligados a um círculo intelectual de judeus convertidos ao protestantismo, do qual faziam parte o músico Felix Mendelssohn, o escritor Heinrich Heine e o teólogo luterano August Neander (nascido David Mendel), entre outras personalidades. A primeira esposa do historiador, Marie Mendelheim, de origem judaica, integrava tal círculo. Ainda que, como observou Momigliano, os convertidos não renegassem por completo sua herança judaica, de forma que a uma profunda fé cristã combinavam a devoção à memória de seus antepassados judaicos, havia uma espécie de norma social que estabelecia o silêncio em relação às suas origens e passado. A esta convenção Droysen teria, de acordo com Momigliano, se conformado por completo, jamais tocando, no decorrer de sua vida, temas relacionados ao judaísmo. Mantivera o silêncio quanto à sua ascendência judaica pelo lado materno na biografia inacabada de seu pai, assim como, no decorrer de sua vida, mantivera o silêncio em relação à ascendência judaica de sua esposa. Diante disto, Momigliano estabelece uma relação entre a norma de silêncio sobre questões relacionadas ao judaísmo que regia a sociedade à qual Droysen pertencia e a interrupção de seus estudos sobre o helenismo. No momento em que a relação entre cristianismo e judaísmo não mais podia ser evitada,

\footnotetext{
${ }^{75}$ Momigliano faz referência à aparição da obra de D. Strauss, The Life of Jesus (1835-36), que segundo o autor chocara, na época de sua publicação, não apenas Droysen, mas muito outros.
} 
Droysen deixaria de lado o tema, abandonando os estudos sobre a Antigüidade para dedicar-se à história moderna.

Poucos anos após a publicação do artigo sobre Droysen, Momigliano oferecia seu próprio quadro das interações culturais e religiosas entre as diferentes civilizações cujo contato ocorrera no decorrer do período que Droysen denominara período helinístico. Este quadro figura em uma série de leituras apresentadas na universidade de Cambridge como Conferências Trevelyan em maio de 1973, repetidas sob forma revisada como Conferências A. Flexner no Bryn Mawr College em fevereiro-março de 1974, nos Estados Unidos. Estas conferências seriam publicadas um pouco mais tarde, em 1975, sob o título Alien Wisdom: The Limits of Hellenization, constituindo a obra mais extensa de Momigliano relacionada ao tema.

Hermes Trimegisto no Egito, Zoroastro e os magos no Irã, os profetas hebreus na Palestina, Confúcio e Lao-Tse na China, a Índia de Buda, os filósofos, trágicos e historiadores gregos - em diversas partes do mundo antigo, no período entre os séculos VII e IV a.C., coexistiram complexas religiões e sistemas de pensamento que, "não tendo nenhuma conexão entre si, constituíram as origens das grandes civilizações históricas mundiais (...) origens [que], em sua própria diversidade, apresentavam algo único”. Buscando estabelecer uma nova filosofia da história, diferente da filosofia cristã, que, “(...) desde Agostinho até Hegel, via no surgimento de Cristo o ponto de inflexão e o centro da história mundial”, ${ }^{76}$ o filósofo alemão Karl Jaspers, nos fins da década de 1940, percebeu tal fenômeno, ao qual chamou Achsenzeit (tempo axial)fenômeno que, de acordo com Hannah Arendt, “oferece a todas as nações um arcabouço comum de autocompreensão histórica”. ${ }^{77}$ Este conceito proposto por Jaspers, Momigliano tomava como ponto de partida para sua abordagem das interações entre gregos, celtas, judeus, romanos e iranianos no contexto do mundo helenístico.

A civilização helenística teria se caracterizado pela crença na superioridade da língua e dos costumes gregos e, neste contexto, a produção intelectual bárbara (nãogrega) em idioma grego que surge a partir do século III a.C., constituía um esforço dos povos bárbaros no sentido de se fazerem conhecer pelos gregos, esforço que era por estes retribuído com interesse pelo estudo das singularidades dos estrangeiros.

\footnotetext{
${ }^{76}$ H. Arendt, Homens em Tempos Sombrios, São Paulo: Companhia das Letras, 1999, pp. 80-81.

${ }^{77}$ Ibidem, p.81
} 
Juntamente com a língua, muitos elementos da cultura helênica foram adotados pelos bárbaros, de forma a caracterizar um "sincretismo assimétrico que foi particularmente bem sucedido na Itália (Etrúria e Roma), deixou sua marca em Cartago, na Síria e no Egito, foi malsucedido na Judéia, bastante insignificante na Mesopotâmia e afetou pelo menos a iconografia, senão a essência, da religião indiana por meio da arte gândara”. ${ }^{78}$ Entre as interações decorridas no contexto sincrético do helenismo, Momigliano destacava a cultura triangular surgida do contato entre Grécia, Roma e Judéia, cuja centralidade estaria garantida, segundo o historiador, enquanto o Cristianismo permanecesse como a religião do Ocidente. Ao passo em que os judeus resistiram à helenização com maior sucesso que outros povos, mantendo em grande parte suas crenças e maneiras de viver, os romanos, por sua vez, assimilaram a cultura grega em tal medida que o historiador grego Políbio pôde encontrar em Roma, de acordo com Momigliano, "uma aristocracia que podia compreender instintivamente, pois compartilhava a sua atitude quanto à vida”. ${ }^{79}$

É relevante que ao abordar os judeus em Alien Wisdom, Momigliano tende, em maior ou menor grau, a encarar o assunto não do ponto de vista dos gregos, mas dos judeus, como bem observou C. G. Starr em sua resenha da obra. ${ }^{80}$ Esta perspectiva, assim como a discussão da relação de Droysen com o judaísmo, que Momigliano propunha não sem ressaltar "o perigo da tarefa de escrever história da historiografia fazendo referência a tabus sociais”, constituem indicações do compromisso do historiador com sua identidade judaica.

\section{IX}

A herança judaica, entretanto, correspondia apenas a uma parcela da totalidade da identidade de Momigliano, sendo a parte italiana desta igualmente importante. Em um discurso proferido no ano de 1977, Momigliano refletia como a relação entre a

\footnotetext{
${ }^{78}$ A. Momigliano, Os Limites da Helenização: A Interação Cultural das Civilizações Grega, Romana, Céltica, Judaica e Persa, Rio de Janeiro: Jorge Zahar Editor, 1991, pp.13-14.

${ }^{79}$ Ibidem, pp.17-29.

80 "The chapter on the Jews are lengthy, and here the author to some degree looks at the subject not from the Greek, but from the Jewish side.” Chester G. Starr, in: The American Historical Review, Vol. 81, No.5 (Dec., 1976). p. 1079.
} 
cultura judaica de sua casa paterna e a cultura italiana do local em que nascera e crescera - a qual o historiador define como uma síntese das culturas cristã, céltica e romana - dera forma, na sua juventude, às concepções políticas, culturais e religiosas de sua vida adulta, provendo os objetivos que perseguiria no decorrer de toda a sua vida acadêmica:

Ich wurde in einem Haus voller Bücher geboren: italienische Bücher, hebräische Bücher, französiche Bücher, lateinische und griechische Autoren entweder im Originaltext oder in der Übersetzung. Jüdisch war unsere Tradition, und tatsächlich gen $\beta$ mein Haus die Reputation eines patriarchalischërdischen Hauses. Aber wir waren ebenso fest mit dem italienischen Land verbunden, in dem unsere Vorfahren seit zweitausend Jahren gelebt hatten, ganz speziell aber mit der Region Piemont, in der die Wurzeln unserer Familie zumindest bis ins fünfzehnte Jahrhundert zurückgingen. Der italienische Risorgimento war für uns ein Ereignis, mit dem wir buchstäblich durch familiäre Bande verbunden waren. Außerhalb des hauses war die kleine Stadt katholisch, aber sie war im 16. Jahrhundert gewaltsam vom Calvinismus wiederbekehrt worden. Zwei Meilen vor der Stadt liegt ein Ort, der den Ruf hat, die römische Siedlung Germanicia gewesen zu sein, angeblich aus der Zeit des Kaisers Claudius. Er faszinierte uns Kinder. Und wir wußten, da $\beta$ Piemont einst Gallia Cisalpina war - ein keltisches Land.

Die Notwendigkeit, zwischen der jüdischen und der italienischen Seit unserer Person Ordnung zu schaffen, bestimmte täglich unser Leben, daneben erfüllte sie unsere Lektüre und unsere Gespräche. Da ich in Spinoza und in die moderne Bibelkritik schon eingeführt wurde, ehe ich ein Bar-Mitzva war, gab es keinen ernsthafen Konflikt zwischen Vernunft und Glauben, sondern vielmehr das Problem, die Elemente der vielfältigen Zivilisation abzuschätzen, deren bewußter Erbe ich war. In einem gewissen Sinne habe ich in meinem Gelehrtenleben nichts anderes getan, als zu verstehen zu suchen, was ich beiden schulde, dem jüdichen Haus, in dem ich erzogen, und dem christlich-römischkeltischen Dorf, in dem ich geboren wurde. ${ }^{81}$

"Nasci em uma casa repleta de livros: livros italianos, livros hebraicos, livros franceses, autores latinos e gregos tanto no original quanto em traduções. Nossa tradição era judaica, e minha casa tinha de fato a reputação de ser uma casa judaica patriarcal. Mas éramos também solidamente ligados à terra italiana, na qual nossos antepassados viveram por dois mil anos, e em especial à região de Piemonte, onde as raízes de nossa família remontam pelo menos ao século XV. O risorgimento italiano foi para nós um evento, ao qual estávamos literalmente ligados por laços familiares. Do lado de fora da casa ficava a pequena cidade católica que fora, entretanto, convertida à força ao calvinismo no século XVI. A uma distância de duas milhas da cidade havia um local conhecido por haver abrigado a colônia romana Germanicia, supostamente do tempo do

\footnotetext{
${ }^{81}$ K. Christ, Neue Profile der Alter Geschichte, Darmstadt: Wiss. Buchges., 1990, p. 250.
} 
imperador Cláudio. Isto fascinava a nós crianças. E sabíamos que Piemont fora a Gália Cisalpina, uma terra céltica.

“A necessidade diária de por em ordem nossos lados judaico e italiano condicionava nossas vidas, além de preencher nossas leituras e conversas. Tendo sido introduzido a Espinoza e à crítica bíblica moderna antes de me tornar um Bar-Mitzva, não havia conflito entre razão e crença, mas antes um problema em avaliar os elementos das diversas civilizações de que eu era um herdeiro consciente. De certa forma, não fiz outra coisa na minha vida acadêmica senão tentar entender o que eu devia tanto à casa judaica em que fui educado quanto à vila cristã-céltica-romana em que nasci.”

Este vínculo da família de Momigliano com a terra italiana e com a região de Piemont se traduzira, no decorrer da década de 1920, na adesão de Riccardo, pai do historiador, ao Partido Fascista. Riccardo Momigliano ocupara o cargo de secretário político do Fascio di Combattimento del Comune di Caraglio entre os anos de 1923 e 1924, passando a regente triúnviro em 1925, secretário político de 1925 a 1927 e comissário extraordinário entre 1929 e 1931, cargo com que terminava sua responsabilidade pública relacionada ao Partido Nacional Fascista. A mãe do historiador, Ilda Levi, fora condecorada com medalha de bronze por seu trabalho na Cruz Vermelha durante a primeira guerra mundial, e teria militado ativamente contra o embargo à Itália que se seguira à agressão à Etiópia. Diante deste contínuo empenho patriótico e político no quadro do regime fascista, a família de Momigliano era reconhecida, no vilarejo de Caraglio, como uma família de judeus fascistas. ${ }^{82}$

O envolvimento de Arnaldo Momigliano com o Partido Nacional Fascista limitara-se, no decorrer da década de 1920, à filiação ao GUP (Gruppo Universitario Fascista) de Torino, mais especificamente ao grupo musical universitário. O vínculo do historiador com o partido foi mantido no decorrer da década seguinte até seu rompimento em 1938, em função das leis raciais que então entravam em vigor. Di Donato propõe que considerações relativas à relação do historiador com o seu presente e à sua progressiva consciência da realidade italiana deverão ter como ponto de partida a atitude de sua família e, em particular, o percurso político do pai, uma vez que o

\footnotetext{
${ }^{82}$ R. Di Donato, “Materiali per una biografia intellettuale di Arnaldo Momigliano", in: Athenaeum Studi di Letteratura e Storia dell'Antichità. Volume Ottantatreesimo, Fascicolo 1, Università di Pavia, 1995, pp. 218-219.
} 
processo educativo de sua infância até o fim da adolescência, quando partia para Torino, ocorrera essencialmente no âmbito doméstico. ${ }^{83}$ Apenas ingressando no ambiente universitário de Torino e sobretudo de Roma, onde contribuiu na empresa da Enciclopedia Italiana sob a direção de Giovanni Gentile e com a orientação de Croce, o jovem Momigliano entraria em contato com a oposição antifascista.

Um quadro das associações e atividades antifascistas de Momigliano no período anterior a 1938 é pelo próprio historiador oferecido em um documento apresentado por Di Donato em Nuovi materiale per uma biografia intellettuale di Arnaldo Momigliano. Trata-se de uma declaração do historiador redigida no período entre junho e novembro de 1940, quando, já há algum tempo na Inglaterra, viria a ser internado em um campo para inimigos estrangeiros, juntamente com os intelectuais italianos Piero Sraffa e Ruggero Orlando.

Ao oficial comandante.

Campo Metropole. Douglas, 24 de Outubro de 1940.

Senhor,

Os fatos a seguir talvez possam auxiliar a autoridade competente a suplementar a evidência a meu respeito fornecida pelo Comitê de Refugiados Judeus. Dois documentos desta evidência - os testemunhos do Prof. Last e Sr. Hardie - oferecem já evidência de minhas opiniões políticas. Atribuo também grande valor à evidência indireta dos testemunhos de dois eminentes liberais antifascistas, Benedetto Croce e Gaetano De Sanctis.

1) Como estudante na Universidade de Torino, publiquei o jornal anti-fascista clandestino "Difesa Liberale" (1926) com meu colega universitário e amigo Aldo Garosci, que mais tarde tornou-se refugiado na França e um dos líderes do movimento "Giustizia e Libertà".

2) Desde 1927 sou amigo dos irmãos Treves. Evidências sobre minhas opiniões políticas a partir deste ano podem, portanto, ser obtidas com o Dr. Paolo Treves, autor de "What Mussolini did to us", de 28 Montague St. WC1.

3) Sou um pupilo de Gaetano De Sanctis, o grande historiador da Antigüidade, e do Professor Giorgio Levi Della Vida. Ambos foram dispensados como liberais pelo Governo Fascista em 1931. Levi Della Vida é atualmente Professor na Universidade da Filadélfia e pode fornecer evidência a meu respeito (Bennet Hall 316 - Philadelfia - U.S.A.).

4) Sou amigo de Croce desde 1930.

5) Entre 1929 e 1933 fui um dos principais contribuidores do [periódico] "La Cultura”, suprimido em 1933 em função de seu caráter liberal.

6) Venho de uma bem conhecida família italiana liberal e antifascista. Meu pai, atualmente refugiado na França, foi líder do Partido Liberal na província de Cuneo e amigo pessoal de Giolitti, nosso M.P. desde 1924. Meu tio Riccardo Momigliano(?), um M.P. antifascista em Como (1919-1924), foi internado por

${ }^{83}$ Ibidem, p.219. 
dois anos na Ilha de Lipari. Meus primos e colegas Felice Momigliano, famoso escritor, e Prof. Attilio Momigliano, principal autoridade em literatura italiana, são personalidades antifascistas bem conhecidas. $\mathrm{O}$ segundo assinou $\mathrm{O}$ “Manifesto” Liberal de Croce em 1924.

7) Em 1933 uma lei tornou a filiação ao Partido Fascista (P.N.F.) condição legal para qualquer posição pública, e pressuposto prático para qualquer emprego privado. Como não possuo meios pessoais, fui forçado a escolher entre a filiação ao P.N.F. ou deixar o país. A última opção era bastante difícil e significava entregar a cultura italiana ao fascismo. O problema, como bem se sabe, é comum aos meus amigos e colegas da Universidade de Roma e da "Enciclopedia" italiana, por haverem solicitado a filiação ao P.N.F. A solução foi aprovada pelos nossos professores antifascistas e tem viabilizado salvar até agora o caráter liberal antifascista da cultura italiana.

8) Minha associação ao P.N.F. era, é claro, totalmente formal.

Em 1934 publiquei meu livro Filippo di Macedonia e em 1937 meu artigo sobre o Império Romano na Enciclopédia Italiana, os quais são considerados na Itália entre os principais produtos da historiografia liberal. Uma resenha do primeiro pode ser encontrada no [periódico] "Classical Review" 1935, e do segundo no "English Historical Review” 1939.

9) Em outubro de 1936 fui suspenso do P.N.F. por tempo ilimitado (ritiro della tessera), já que não estava comparecendo aos encontros do Partido; em 1938 fui definitivamente expulso em função das leis raciais.

10) Em 1935-36 meu ponto de vista pró-Inglaterra era notório: um traço claro disto está em meu estudo the modern historiography about the Roman Empire, na “Rivista Storica Italiana” 1936.

11) Acredito poder dizer que minhas aulas na Universidade de Torino foram famosas por sua tendência abertamente liberal.

Não tenho dúvidas de que os fatos acima deixarão claro que a causa pela qual a Grã-Bretanha luta coincide com a minha, e que ficarei muito honrado em tomar parte no esforço nacional.

Respeitosamente,

Arnaldo Dante Momigliano - 44370.”84

As informações contidas no documento - algumas delas novidades absolutas, como a participação de Momigliano em um jornal antifascista clandestino em meados da década de 1920 - necessitam ainda uma verificação acurada. Di Donato aponta para o caráter fortemente sugestivo de algumas delas, sobretudo aquela relativa ao percurso do pai, sobre quem o historiador falara a verdade, mas apenas parte da verdade, omitindo sua ligação ao PNF. A verificação de tais informações e a definição de um quadro mais exato do posicionamento político de Momigliano no período pré-exílio requer, entretanto, o acesso a uma documentação mais ampla.

\footnotetext{
${ }^{84}$ R. Di Donato, “Nuovi materiali per uma biografia intellettuale di Arnaldo Momigliano”, in: Rendiconti Morali Accademia dei Lincei, 11 (2000), n. 1, pp. 391-392.
} 
A posição ambígua de Momigliano em relação ao fascismo em meados da década de 1930 necessita ser analisada à luz de sua condição de judeu italiano e da igualmente ambígua política fascista relativa à população judaica italiana. O período de fundação do império entre os anos de 1935 e 1937 constituiu o momento de máximo consenso entre o povo italiano e o regime fascista; o sucesso da guerra na África suscitara a adesão dos italianos e a popularidade de Mussolini atingia seu ápice. A atitude dos judeus italianos no período, como observou Renzo De Felice em sua obra Storia degli ebrei italiano sotto il fascismo, ${ }^{85}$ não se distinguia daquela dos demais italianos: compartilhavam o sentimento geral de confiança e simpatia pela Itália fascista e por Mussolini. O duce, por sua vez, afirmava e reafirmava a impossibilidade da existência de uma questione ebraiche no país; o antisemitismo era tido então como estranho à psicologia dos italianos, que à sua manifestação em países estrangeiros reagiam com desdenho. O antisemitismo promovido por alguns jornais fascistas constituía, diante deste quadro, manifestações periféricas, insuficientes para abalar a segurança da comunidade judaica italiana.

Com o estreitamento das relações entre Itália e Alemanha e a guerra na Espanha em 1936, entretanto, o sentimento de segurança se deteriorava e o ataque aos judeus se fazia progressivamente mais vasto e concreto. Nesse contexto ocorria, em abril de 1937, a publicação do panfleto Gli ebrei in Italia de Paolo Orano, um impetuoso ataque que não se limitava aos sionistas e internacionalistas, mas à totalidade da comunidade judaica italiana, judeus fascistas inclusos. A polêmica relacionada ao sionismo não era nova e tampouco a argumentação de Orano, que denunciava a estreita relação entre Israel e Inglaterra, propondo que o sionismo servia aos interesses britânicos, estando conseqüentemente em conflito com os interesses italianos. A novidade na argumentação de Orano constava na denúncia inédita da individualização e segregação da comunidade judaica fascista, as quais, segundo o autor do panfleto, se estendiam para além do âmbito religioso. O Estado fascista, sendo totalitário, não poderia admitir tal individualização de um grupo em seu interior. Os judeus italianos deveriam, portanto, não apenas posicionar-se explicitamente contra o sionismo e o comunismo, mas

\footnotetext{
${ }^{85}$ Renzo De Felice, Storia degli ebrei italiani sotto il fascismo, Milano: A. Mondadori, 1977.
} 
igualmente renunciar a toda a sua individualidade com excessão daquela circunscrita em um âmbito estritamente religioso.

À publicação do panfleto de Orano seguiu-se um clamor sempre crescente de acusações e uma significativa mudança no tom do discurso dos veículos de comunicação oficiais do Estado. O perigo de uma passagem da propaganda à ação antisemita, que se tornava então eminente, foi recebido pela comunidade judaica italiana com reações diversas. Alguns, incrédulos em relação a um antisemitismo de Estado no país ou repugnados e resignados com a situação, restringiram-se a um silêncio dignitoso, ao passo que outros passaram a exprimir publicamente sua italianidade e expressar sua aversão pelo sionismo, esperando convencer Mussolini da boa fé dos judeus italianos ou distinguir-se do restante de seus correligionários.

Exposta a uma massiva campanha de calúnia e denigrição, a comunidade judaica italiana era marcada internamente por profundas divergências, situação que é estudada em detalhe por De Felice no subcapítulo Gli sviluppi della situazione all'interno dell'ebraismo italiano de seu livro. ${ }^{86}$ Uma carta de Momigliano endereçada à Comunidade Israelítica de Roma, redigida nos primeiros meses de 1937, logo após a publicação do panfleto de Orano, fornece indícios que permitem mapear a posição de Momigliano em tal contexto. ${ }^{87} \mathrm{Na}$ carta, Momigliano fazia uma série de objeções às posições adotadas pelos dirigentes da Comunidade, a quem acusava, em primeiro lugar, de haverem apoiado por anos o falecido presidente da União das Comunidades (Felice Ravenna), a quem responsabilizava pela maior parte da desconfiança que recaia então sobre os judeus italianos. Momigliano condenava em seguida a escolha de um exorganizador sionista para novo rabino líder da comunidade (David Prato, sucedendo o falecido Angelo Sacerdoti), de acordo com o historiador a pessoa menos indicada para ocupar a posição - crítica que se pressupõe já acatada pelos representantes da comunidade, uma vez que Momigliano indica estarem eles de acordo que tal escolha haveria constituído um erro -, e reprimia os líderes da comunidade por não haverem

\footnotetext{
${ }^{86}$ Renzo De Felice, Storia degli ebrei italiani sotto il fascismo, pp. 267-283.

${ }^{87}$ A carta é parte de uma série de documentos relativos ao período, compilados por Di Donato em seu artigo "Materiali per una biografia intellettuale di Arnaldo Momigliano", Athenaeum, 1995. Trata-se de um envelope que trazia manuscrita a inscrição Questione ebraiche, no qual Momigliano mantinha diversos recortes de jornais de 1936 e 1937, todos relativos à questão hebraica na Itália, além de cópias de uma séries de cartas de sua autoria.
} 
mantido, diante disso, a mais estreita "vigilância preventiva” sobre o novo rabino, permitindo que este assinasse um documento não especificado no contexto da carta, apenas descrito como similar a outro que o historiador já denunciara em carta anterior. Diante destes argumentos, Momigliano propunha que questões como estas tornavam a permanência em uma Comunidade Israelítica “incompatível com a adesão profunda e total à vida nacional italiana como única vida real e única vida possível di um cidadão proveniente de família hebraica.”

O discurso de Momigliano no trecho da carta de 1937 a seguir ecoava, embora em diferente tom, o discurso de 1977 a respeito da tradição familiar de devoção à pátria italiana e à religião judaica à qual se incorporava:

$\mathrm{Al}$ sottoscritto compiere il passo di uscire dalla Comunità non costituisce grave difficoltà: egli (...) non solo aborre dall'Ebraismo come nazionalità ma non si sente nemmeno ebreo religiosamente: egli si mantiene iscritto a una Comunità per un consapevole rispetto alla tradizione dei suoi padri, che hanno conservato e conservano profondamente simile nel loro cuore la devozione alla patria italiana e la devozione alla religione israelitica. Se taluni capi delle Comunità israelitiche sapessero per avventura più associare o dimostrare di associare questi due sentimenti, cesserebbe l'unica ragione al sottoscritto di appartenere a una Comunità. ${ }^{88}$

A devoção patriótica, herança da casa paterna, e a vida nacional italiana, "única vida real e possível”, Momigliano concebia, naquele momento, nos termos propostos pelo regime fascista. A negação do judaísmo como nacionalidade em seu discurso reforça o quadro proposto por Dionisotti em seu Ricordo, no qual contrapõe à fidelidade do jovem Momigliano à religião de seus ancestrais, sua recusa em relação à segregação e ao isolamento, e o "richiamo alla tradizione risorgimentale italiana e a una comunità di studi internazionale, rispettosa a pari titolo delle differenze religiose, come di quelle linguistiche e politiche" ${ }^{89}$ No mesmo sentido aponta a observação G. W. Bowersock de que Momigliano, no contexto da década de 1930, teria acreditado que poderia encontrar "uma forma de acomodar o clima intelectual da época com suas pesquisas desinteressadas," pensado os judeus como “uma nação no interior de outra nação”. Esta idéia seria por Momigliano abandonada após a Segunda Guerra Mundial, quando

\footnotetext{
${ }^{88}$ R. Di Donato, "Materiali per una biografia intellettuale di Arnaldo Momigliano”, in: Athenaeum Studi di Letteratura e Storia dell'Antichità. Volume Ottantatreesimo, Fascicolo 1, Università di Pavia, 1995, p. 226.

${ }^{89}$ C. Dionisotti, Ricordo di Arnaldo Momigliano, Il Mulino, Bologna, 1989, p. 82.
} 
passaria, ainda de acordo com Bowersock, a enfatizar cada vez mais a separação dos judeus, tanto no contexto da Antigüidade quanto do presente. ${ }^{90}$

O triênio 1935-1937 constituíu, de acordo com Renzo De Felice, “da um lato (...) per la grande maggioranza degli ebrei italiani anni di pacifico lavoro, di speranze, di fiducia e di partecipazione allo stato d'animo collettivo della loro patria”. Nesta maioria se inseria o jovem Arnaldo Momigliano. Em 1936, quando fazia sua leitura inaugural em Torino, e no breve período que se seguiu até que a perseguição aos judeus por parte do Estado italiano se tornasse uma realidade concreta, é possível que o historiador acreditasse e esperasse que, no contexto político que se desenrolava, uma nova pax romana pudesse proteger os judeus da perseguição. ${ }^{91}$

Com os eventos transcorridos a partir de 1938 e o exílio na Inglaterra a partir de 1939, a reflexão de Momigliano se desenvolve e as convicções da juventude são questionadas. Nesse sentido, a reformulação do texto da leitura inaugural de 1936 para as lições de Cambridge em 1940 aparece como um indício dos rumos deste desenvolvimento.

\section{$\mathbf{X I}$}

Na terceira e quarta lições apresentadas em Cambridge, entituladas respectivamente Pace e Libertà degli antichi, Momigliano retomava, como visto, o texto de sua leitura inaugural sobre a paz no mundo antigo, apresentada em Torino no ano de 1936. Na lição seguinte, Libertá degli moderni, outra antiga discussão era retomada, desta vez aquela relativa à nota de Croce de 1930, sobre a diferença entre a liberdade de antigos e modernos.

Neste contexto, à discussão que envolvia os textos de Constant e Jellinek somavam-se dois discursos de Lord Acton, “The History of freedom in Antiquity” e “The History of freedom in Christianity”, ambos de 1877. Em carta ao amigo Carlo Dionisotti de março de 1940, Momigliano aludia aos textos em que Lord Acton, “com

${ }^{90}$ G. W. Bowersock, "Momigliano’s Quest for the Person”, in: History and Theory, Vol. 30, No. 4, pp. 27-36.

${ }^{91}$ Como propôs R. Di Donato in: Athenaeum Studi di Letteratura e Storia dell'Antichità. Volume Ottantatreesimo, Fascicolo 1, Università di Pavia, 1995, p. 228. 
menos genialidade que Constant, mas com interessante ponto de vista”, abordara o problema da liberdade antiga e moderna. ${ }^{92}$ Constant teria sido o primeiro a apontar a diferença entre a liberdade antiga, que identificava como liberdade política, e liberdade moderna, que identificava como liberdade individual. Os pressupostos dos quais partiam Constant e Lord Acton eram próximos; o último, porém, não teria negligenciado os problemas do cristianismo e da liberdade religiosa, para os quais Momigliano já chamava a atenção em seu comentário à nota de Croce. Lord Acton enfatizava, assim como Constant, o caráter individual da liberdade moderna, porém para o último a liberdade individual constituía a própria forma da liberdade moderna, enquanto para Lord Acton ela era condição para uma vida religiosa - a liberdade religiosa constituía o mais importante aspecto da liberdade moderna.

Entre os problemas que identifica na interpretação de Lord Acton, Momigliano aponta que nela se confundem o direito à consciência religiosa, afirmado pelo Cristianismo contra o Estado, e o direito à consciência individual, "che non erano conosciuti o proclamati dal Cristianesimo e dovevano attendere più di milliseicento anni per essere riconosciutu nella folosofia e nella política moderna”. ${ }^{93}$ Momigliano observa também que Lord Acton considerava a idéia de liberdade apenas do ponto de vista da consciência e dos direitos individuais, de forma que não achou necessário estabelecer o nascimento da idéia de liberdade pessoal em oposição à liberdade política. Para o historiador italiano, como visto, duas fases distintas da liberdade antiga podiam ser identificadas: a primeira correspondendo à liberdade política e a segunda a um ideal de paz da consciência. Estas podiam ser identificadas respectivamente na descoberta de Constant e na interpretação proposta por Lord Acton. ${ }^{94}$ Lord Acton, dessa forma, complementaria Constant ao alertar para a importância da experiência do cristianismo no desenvolvimento da idéia de liberdade, a qual Momigliano considerava a “experiência fundamental e definitiva do mundo antigo”.

Os temas paz e liberdade, anteriormente abordados separadamente, passam a ser progressivamente compreendidos por Momigliano como um único problema. Na mesma carta a Dionisotti em que comentava seus estudos dos textos de Lord Acton,

\footnotetext{
${ }^{92}$ Carlo Dionisotti, Ricordo di Arnaldo Momigliano, p.104.

${ }^{93}$ A. Momigliano, Pace e libertà nel mondo antico - Lezioni a Cambridge: gennaio-marzo 1940, Firenze: La Nuova Italia Editrice, 1996, p. 63.

${ }^{94}$ Ibidem, p. 64.
} 
Momigliano propunha a identificação do problema da paz no mundo clássico como a forma histórica assumida pelo problema da liberdade a partir do final do IV século:

Le lezioni si sono naturalmente risolte in uno schizzo di Freedom and peace in the classical world. Nel mio molto occuparmi di questi due temi c'era sempre stata una oscura consapevolezza della loro unità, ma solo da poco ho capito chiariamente che il problema della pace, e in particolare della pace interiore, è la forma storica concreta del problema della libertà dalla fine del IV sec. a.C. al Baso Impero...

No texto da lição de Cambridge, o Cristianismo era proposto como uma reação à paz tirânica e autoritária imposta por Roma. Uma necessidade espiritual de liberdadeesta identificada por Momigliano nos termos da filosofia croceana, como "força eterna da atividade humana” - teria conduzido à reinvindicação de uma paz espiritual, que se opunha à paz política e militar do Império. O cristianismo, identificado pelo historiador como a mais séria tentiva de se alcançar uma paz de espírito, corresponderia assim à forma que o problema da liberdade assumia no final da Antigüidade.

Uma definição de liberdade é assim proposta por Momigliano, ancorada em dois elementos fundamentais, sendo o primeiro deles a autonomia, faculdade do indivíduo de encontrar em si mesmo as regras para a vida, e o segundo a liberdade de ação, faculdade de exteriorizar no mundo as sugestões da consciência moral. O ideal de paz da alma ou paz interna enfatizaria, de acordo com o historiador, o elemento de autonomia: mesmo quando a ação externa é impossível, a autonomia pode ser preservada, obedecendo-se a uma ordem universal, ao kosmos, a Deus. Momigliano destaca assim a inexistência de uma oposição política efetiva ao Império, enfatizando o elemento de autonomia da liberdade professado por estóicos e cirstãos, chamando a atenção para o caráter apolítico dos ideais de paz professados por estes grupos.

Estabelecida a unidade entre os problemas da paz e liberdade, Momigliano identificava sua motivação pessoal para o estudo de cada um deles como manifestações de um único interesse espiritual:

Certamente, non è facile riconoscere immediatamente che questi due problemi della libertà e della pace, che sono tanto preminenti nel mondo classico, sono due aspetti dello stesso problema, o, meglio, che il problema della pace è uma forma più tarda dello problema della liberta. Ma un esame attento rimuove ogni dubbio. Posso forse richiamare la mia propria esperenzia. Per molti anni ho studiato i problemi della libertà e della pace nel mondo ântico come due diversi problemi. Solo lentamente, l'analisi accutara dei due termini mi ha costretto a

\footnotetext{
${ }^{95}$ C. Dionisotti, Ricordo di Arnaldo Momigliano, 1989, p. 103.
} 
riconoscere che il problema che stavo studiando era uno solo; ed uno ancora l'interesse spirituale che mi muoveva nella ricerca. ${ }^{96}$

\section{XII}

O livro de Momigliano sobre paz e liberdade no mundo antigo jamais seria concluído. Uma série de fragmentos de cartas do historiador enviadas ao amigo Carlo Dionisotti no decorrer da década de 1940, publicados por este em seu Ricordo, fornecem um quadro do desenvolvimento da composição do livro, ao qual Momigliano se dedicou durante todo o período da guerra, e dos motivos para a sua falta de êxito na realização do projeto e no cumprimento de seu contrato com a Clarendon Press. Ao não cumprimento deste contrato, Oswyn Murray atribui o posterior distanciamento de Momigliano em relação à Oxford - referindo-se ao período pós-1951, quando o historiador assume a cátedra de história antiga na University College London -, sugerindo a possibilidade de um desconforto latente da parte do historiador em função da obrigação não cumprida. ${ }^{97}$

O primeiro dos fragmentos publicados por Dionisotti, datado de março de 1940, corresponde ao período da composição dos textos das lições de Cambridge e da conferência de Oxford. Nele, como visto, Momigliano mencionava a identificação do problema da paz como a forma histórica assumida pelo problema da liberdade a partir do IV século a.C., estabelecendo entre eles uma unidade, além de seu estudo da obra de Lord Acton e a contribuição deste para a discussão das diferenças entre liberdade de antigos e modernos.

No fragmento seguinte, de outubro de 1944, Momigliano relembrava o período em que estivera internado com Piero Sraffa e Ruggero Orlando no Metropole Camp, no qual teria iniciado com a República de Platão e a Política de Aristóteles a leitura “de toda a literatura clássica e muito da literatura pós-clássica”, as quais incorporavam o programa de trabalho para a composição de seu livro, cujo escopo se estendia, neste momento, de Homero a Santo Agostinho. Neste contexto um primeiro indício de

\footnotetext{
${ }^{96}$ A. Momigliano, Pace e libertà nel mondo antico, 1996, pp. 58-59.

${ }^{97}$ O. Murray, "Momigliano in England”, in History and Theory, vol. XXX, n.4, Beiheft 30, 1991, p. 53.
} 
incerteza quanto à viabilidade da realização do projeto pode ser identificado: “fino a qual punto questo lavoro riuscirà a trovare la sua forma nel libro 'Pace e libertà nel mondo antico da Omero a Sant'Agostino' non mi è possibile dire: inteiri capitoli sono scritti, ma dovranno essere riscritti, altri sono apena abbozzati”. ${ }^{98}$

Com o fim da guerra e a possibilidade de um retorno à Itália, Momigliano escrevia a Dionisotti, em novembro de 1945, que estando na Inglaterra ou na Itália, trabalharia no primeiro volume de seu livro, esperando poder apresentar à Claredon Press boa parte do trabalho concluído até o final do ano seguinte e persuadi-los da necessidade de um período de mais três ou quatro anos para a conclusão do projeto. A menção de um primeiro volume, pressupondo uma partição não prevista no projeto original do livro, constituiria indicação da impossibilidade por parte do autor de conciliar em um único estudo os diversos aspectos da pesquisa.

No último fragmento publicado por Dionisotti, de carta de fevereiro de 1946, a crescente dificuldade na realização do projeto é evidente. O período de quatro a cinco anos previsto para a conclusão do livro na carta anterior, poucos meses antes, não mais parecia viável: “... Sarrei francamente lieto si potessi condurre a buon termini in dieci anni uma vera ricostruzione della esperienza etico-politica antica, pagana e cristiana.”99 Planos de finalização de um primeiro volume eram ainda mencionados na carta, os quais não se concretizariam. Traços da pesquisa realizada, entretanto, seriam recorrentes no trabalho posterior de Momigliano, sobretudo em seus estudos sobre a Antigüidade tardia. $^{100}$

Ainda no último fragmento, Momigliano anunciava a composição de um ensaio sobre Friedrich Creuzer e a origem do estudo da historiografia grega, o qual integrava uma linha de pesquisa norteada para o estudo do método histórico e da história da historiografia, concebida então pelo historiador como "maggiore o menore secondo gli

\footnotetext{
${ }^{98}$ C. Dionisotti, Ricordo di Arnaldo Momigliano, 1989, p. 104. Em relação à passagem, Di Donato elenca alguns textos de leituras e conferências que afirma constituírem os textos aos quais Momigliano se refere ao mencionar capítulos a serem reescritos e esboços, sendo eles: a) as lições de Cambridge de JaneiroMarço de 1940; b) a conferência de Oxford de maio de 1940; c) a leitura sobre "the Crisis of the Roman State and the Roman Historians (from Sallust to Tacitus)" e d) a leitura sobre "The Polis and the suppliant", ambas de 1942; em R. Di Donato, "Materiali per una biografia intellettuale di Arnaldo Momigliano", in: Athenaeum Studi di Letteratura e Storia dell'Antichità. Volume Ottantatreesimo, Fascicolo 1, Università di Pavia, 1995, pp. 238-239.

${ }^{99}$ Ibidem, p. 105.

${ }^{100}$ Como observado em O. Murray, op. cit., p. 53.
} 
umore”. Nos anos que se seguiriam, os estudos no campo da história da historiografia, iniciados com o ensaio sobre Creuzer, viriam a figurar como o tema central da produção de Momigliano, como será visto no capítulo seguinte. 


\section{Capítulo 2}

\section{História da historiografia}

Após seis anos de exílio na Inglaterra, Momigliano retornava à Itália em junho de 1946 para uma estada de um mês em seu país de origem. Às vésperas de seu retorno à Inglaterra, recebia de Benedetto Croce o convite para assumir a direção de seu Istituto storico, que seria fundado ainda naquele ano, em Nápoles. Momigliano recusaria este convite, sem, no entanto, descartar o plano de um retorno à Itália. Na carta a Croce em que anunciava sua recusava, datada do mês de setembro daquele ano, expressava sua aspiração de ligar-se à Scuola di Roma como sucessor de De Sanctis ou Cardinale. ${ }^{1}$

Com o fim da guerra, não apenas as perspectivas de Momigliano em relação à sua carreira mudavam, mas também os rumos de sua produção historiográfica. O ano de 1946 marcou o evento que Oswyn Murray caracterizou como "the crucial turningpoint”2: Arnaldo Momigliano anunciava, para o desânimo de seus colegas de Oxford, que dedicaria sua pesquisa futura à história da historiografia. ${ }^{3}$ Tema marginal, a história da historiografia era, segundo Murray, "utterly alien to the English tradition of historical writing (...), generally despised, regarded as a waste of time”. ${ }^{4}$ T. J. Cornell observa que havia naquele tempo, na Inglaterra, um sentimento de que os historiadores das gerações passadas tinham pouco a ensinar. ${ }^{5}$

Os primeiros indícios do novo direcionamento dado por Momigliano à sua pesquisa aparecem no artigo Friederich Creuzer and the Greek historiography, publicado no Journal of Walburg and Courtland Institutes, em 1946. O artigo não

\footnotetext{
1 Uma abordagem detalhada da relação intelectual e pessoal entre Benedetto Croce e Arnaldo Momigliano consta no artigo de Carlo Dionisotti, "Momigliano e Croce”, in: Belfagor, 43, 1989 pp. 617641.

2 Oswyn Murray, Arnaldo Momigliano in England, in: History and Theory, vol. XXX, n.4, Beiheft 30, 1991. p. 54.

3 Tanto Oswyn Murray como T. J. Cornell fazem referência ao evento. Cornell estabelece a sua data em 1946 e Murray atribui a Dan Davin, assistente de Keneth Sisam, editor da Oxford University Press, a memória do anúncio de Momigliano e o desânimo com que foi recebido.

${ }^{4}$ Oswyn Murray, op. cit. p. 54.

${ }^{5}$ A. Momigliano, A.D. Momigliano: Studies on Modern Scholarship. Ed. G.W. Bowersock and T.J. Cornell. University of California Press, 1994. p. xi-xii.
} 
aborda a obra mais conhecida de Creuzer, Symbolic und Mythologie der alten Völker, de 1810-12, mas sua produção de um período anterior, cujo objeto era a historiografia grega. Mais tarde, o interesse de Momigliano na obra de Creuzer seria avaliar as posições ocupadas por Tucídides e Heródoto no pensamento historiográfico romântico do século XIX; ${ }^{6}$ no artigo em questão, o problema colocado era o da relevância dos estudos em história antiga para o contexto da história em geral. Se na época da publicação do primeiro volume de Historische Kunst der Griechen de Creuzer, em 1803, "what was done in ancient history was then immediately relevant to history in general”, em meados do século XX, quando Momigliano escrevia seu artigo, “ancient history has become a provincial branch of history". ${ }^{7}$ Para Momigliano, a história antiga recuperaria seu prestígio apenas se provasse ser mais uma vez capaz de oferecer resultados que afetassem as perspectivas da produção histórica contemporânea em sua totalidade. Como um dos caminhos possíveis para que isso viesse a se concretizar, propõe uma retomada do contato com autores do passado que trataram "assuntos clássicos de importância vital para a história em geral”. ${ }^{8}$ Creuzer, com sua obra Historische Kunst der Griechen, seria um desses autores, justamente por sua proposta de uma história da historiografia.

A idéia da necessidade de se retomar historiadores de gerações anteriores para solucionar problemas presentes, apresentada no artigo sobre Creuzer, consiste na premissa que nortearia toda a produção de Momigliano, tanto no campo da história da historiografia como no campo da história antiga. P. A. Brunt (sucessor de Ronald Syme em sua cadeira em Oxford), ao resenhar o Secondo contributo alla storia degli studi classici, de 1962, percebeu com agudeza o que havia de peculiar no método de pesquisa histórica empregado por Momigliano:

(...) despite the book's title, Momigliano has much to say about classical antiquity in its own right, and not merely on the history of classical scholarship. That subject might indeed seem to be quite distinct, to be part of the history of periods in which the classical scholars discussed wrote, rather than the periods to which their studies refer, and to demand knowledge (which Momigliano possesses) even more of the intellectual climate of their times, which partly determined their interests and opinions, than of classical antiquity itself. (...) It would often seem that he has entangled the two

\footnotetext{
${ }^{6}$ A. Momigliano, As Raízes Clássicas da Historiografia Moderna, Bauru, SP: EDUSC, 2004. p. 79.

${ }^{7}$ A. Momigliano, Contributo alla storia degli studi classici, Roma, 1955. p. 232.

${ }^{8}$ Ibidem, p. 234.
} 
subjects, as if we must always look at problems of ancient history first through the eyes of all who have previously tried to solve them. ${ }^{9}$

Brunt continua, apontando os benefícios que o procedimento por ele identificado na obra de Momigliano pode oferecer:

What can be gained from this procedure? A wide knowledge of what has been studied in the past, coupled with breadth of interests and visions, makes it easier to discover new problems, new lines of inquiry. (...) Interpretations of past history or historians are often influenced by the conditions of the present (...) and it may be that if we are more fully conscious of the anachronisms and errors into which our predecessors have fallen under such influences, we shall be better placed to limit the subjectivity which must in some measure distort our own interpretations. ${ }^{10}$

O texto de Brunt ecoa a formulação proposta pelo próprio Momigliano a respeito da importância dos estudos em história da historiografia como meio de se impor um limite à subjetividade na abordagem de problemas históricos. Para Momigliano, a história da historiografia constituiria, além disso, ferramenta fundamental para a compreensão da própria história:

(...) the importance of the history of historiography is beyond question. No real understanding of history is possible where it is no longer possible to discover the meaning that past generations gave to facts we are studying. The Middle-Ages have no historiography because nobody was able to understand that ancient people thought in a different way. We must know the meaning of the problems from which our problems derive. On the other hand our problems lose their subjectivity only if we can justify them by comparison with the problems of other people. The universality of historical thinking remains in the understanding of those problems which are no longer ours. ${ }^{11}$

O trecho acima consta no texto da conferência de Momigliano à Oxford Philological Society, de maio de 1940. Seis anos antes, portanto, do anúncio aos seus colegas de Oxford e do artigo sobre Creuzer, ainda no início de seu exílio na Inglaterra, Momigliano já apresentava com clareza as premissas que norteariam seus esforços para o campo da história da historiografia. Nesse sentido, já em sua monografia sobre Felipe da Macedônia de 1934, como observou Karl Christ, elementos da tradição

\footnotetext{
${ }^{9}$ P. A. Brunt, "Historical Studies”, in: The Classical Review, Vol. 11, No. 2 (Jun., 1961), p. 141.

${ }^{10}$ Ibidem, pp. 141-142

${ }^{11}$ Ricardo Di Donato, "Materiali per una biografia intellettuale di Arnaldo Momigliano”, in: Athenaeum Studi di Letteratura e Storia dell'Antichità. Volume Ottantatreesimo, Fascicolo 1, Università di Pavia, 1995. p. 234.
} 
historiográfica eram considerados significantes. ${ }^{12}$ Outros artigos, como Per il centenário dell' “Alessandro Magno” di J. G. Droysen (1933); Studien über griechische Geschichte in Italien von 1913-1933 (1934); e La formazione della moderna storiografia sull'imperio romano (1936), indicam que o estudo da historiografia moderna sobre a Antigüidade fora, desde o início, uma preocupação de Momigliano, ainda que não constituísse o principal foco de sua produção. Dessa forma, o artigo de 1946 sobre Creuzer marca mais propriamente o início da produção de Momigliano no campo da história da historiografia em língua inglesa (e o início dos estudos nesse campo que culminariam, no início da década de 1960, nas leituras apresentadas sob o título The Classical Foundations of Modern Historiography).

\section{II}

O filósofo Benedetto Croce ocupou uma posição hegemônica no pensamento intelectual italiano da primeira metade do século $\mathrm{XX}^{13}$ e exerceu importante influência sobre Momigliano no período de sua formação na década de 1930. Foi na filosofia de Croce que Momigliano encontrou os fundamentos para a formulação de seu pensamento sobre a história da historiografia - o qual se manteria inalterado no decorrer de toda sua produção acadêmica, ganhando centralidade no contexto desta a partir de meados da década de 1940. O pensamento teórico de Croce sobre a história, cuja primeira forma aparecia em 1893 com o ensaio La Storia ridotta sotto il concetto generale dell' Arte, alcançaria sua forma final - como observa Collingwood,$-{ }^{14}$ nas formulações contidas nos ensaios por ele redigidos entre 1912-13, que viriam a ser publicados na Itália em

\footnotetext{
${ }^{12}$ Karl Christ, "Arnaldo Momigliano and the history of historiography", in: History and Theory, vol. XXX, n.4, Beiheft 30, 1991. p. 4.

13 "Not since Goethe," observou H. Stuart Hughes, "had any single individual dominated so completely the culture of a major European country". H. S. Hughes, Consciousness and Society, New York, 1958, p. 201. Apud Edmund E. Jacobitti, "Hegemony before Gramsci: The Case of Benedetto Croce", in: The Journal of Modern History, Vol. 52, No. 1 (Mar., 1980), p. 68.

O contexto que resultaria na hegemonia do pensamento croceano na Itália, principalmente no período entre 1925-40, é discutido por Momigliano no artigo "Reconsidering B. Croce", de 1966. In: A. Momigliano, A. D. Momigliano: Studies in Modern Scholarship. University of California Press, 1994. pp. 80-96.

${ }^{14}$ R. G. Collingwood, The Idea of History, Oxford University Press, 1951, p. 201.
} 
1917 sob o título Teoria e storia della storiografia. ${ }^{15}$ De acordo com Momigliano, teria sido com esta obra, juntamente com a Storia della storiografia italiana nel secolo decimonono (1918) e com os trabalhos propriamente historiográficos publicados a partir da década de 1920 - Storia del regno di Napoli (1924), Storia d'Italia dal 1871 al 1915 (1928), Storia dell'età barocca in Italia (1929) e Storia d'Europa nel secolo decimonono (1932) - que Croce começaria a interessar jovens historiadores na Itália apesar da centralidade que ocupava a história em seu pensamento, sua influência havia, até então, se restringido a outros campos, sobretudo ao da crítica literária. ${ }^{16}$ Entre estes jovens historiadores que se passavam a se interessar pelo pensamento do filósofo, incluía-se o próprio Momigliano, então estudante universitário de história na Universidade de Torino. A relação do jovem Momigliano com Croce no início da década de 1930 foi descrita por Carlo Dionisotti como “culto di quei giovani per un maestro lontano e avverso, (...) una velleità naturale di indipendenza e di censura nei confronti dei maestri vicini” ${ }^{17}$ - ainda que não faltasse a Momigliano respeito e admiração por seu maestro vicino, o católico Gaetano De Sanctis.

No prefácio a uma compilação de artigos seus, publicada em Torino no ano de 1984, Momigliano estabelecia um vínculo entre os artigos na obra compilados, escritos em um intervalo de quase cinqüenta anos (1933-1981), em torno da peculiaridade que Brunt percebera em seu método, a constante necessidade de um retorno às origens dos problemas históricos e às abordagens de tais problemas propostas por historiadores de gerações anteriores, cuja origem identifica nos ensinamentos de Croce:

Anche se tra gli intervalli del mio lavoro non ci fosse stata la mia cacciata come ebreo dalle Università italiane nel 1938 con la conseguente necessità di acquistare una nuova lingua e assorbire una nuova cultura per insegnare, non si sarebbe da aspettarsi continuità di temi e di metodi in questi saggi. Se c'è continuità è paradossalmente dovuta al bisogno costante di sapere come e quando un determinato problema storico che mi stava occupando fosse nato e fosse stato affrontato dai miei predecessori. Che la storia della storiografia aiuti a definire, affrontare e risolvere $\mathrm{i}$ singoli problemi storici era un insegnamento basilare di Benedetto Croce a cui spero di essere rimasto con senso di gratitudine. ${ }^{18}$

\footnotetext{
15 Num primeiro momento, publicados na Alemanha no livro Zur Theorie und Geschichte der Historiographie (Tübingen, 1915).

16 A. Momigliano, A.D. Momigliano: Studies on Modern Scholarship, Ed. G.W. Bowersock and T.J. Cornell. University of California Press, 1994. p.85.

${ }^{17}$ C. Dionisotti, op. cit., p. 619.

${ }^{18}$ A. Momigliano, Sui fondamenti della storia ântica, Torino: Giulio Einaudi editore, p. VIII.
} 
Em 1987, ano de seu falecimento, no prefácio a outra compilação de artigos editada em Bolonha por Emilio Gabba -, Momigliano volta a atribuir a Croce a origem de sua consciência da necessidade de se recorrer às origens dos problemas históricos e aos historiadores que deles se ocuparam anteriormente:

Ma il mio tempo è stato anche il tempo dellidealismo italiano, e in particolare di Benedetto Croce. E da Benedetto Croce, che fu per noi voce di libertà e di italica gentilezza, un insegnamento credo di aver ritenuto, se anche mi sia poi sembrato caduco: la necessità di rendersi conto delle origini dei problemi e delle riposte da altri date prima di noi. ${ }^{19}$

As referências a Croce nestes dois contextos, nos quais Momigliano, no final de sua vida, lança um olhar retrospectivo sobre sua carreira acadêmica, estabelecem em torno dos ensinamentos do filósofo um vínculo entre os diferentes momentos de seus estudos, sobretudo entre o período de sua produção na Itália, anterior ao exílio, que se inicia com o ingresso de Momigliano na vida universitária em meados da década de 1920, e o período de sua produção na Inglaterra, a partir de seu exílio em 1939.

A história, como já mencionado, tinha importância central no pensamento filosófico de Croce. Negando a possibilidade da distinção entre universal e particular proposta pela Lógica tradicional, Croce presumia a presença necessária de ambos os âmbitos em toda a cognição real, de forma que uma relação mútua indissolúvel entre filosofia (julgamento universal) e história (narrativa do individual) era estabelecia. ${ }^{20} \mathrm{~A}$ história teria como objeto o individual, que por sua vez é pensado através de conceitos universais, próprios da filosofia. Diante disso, Croce inverte o quadro até então comumente assumido pelos filósofos, que estabelecia a filosofia como rainha das ciências e a história como um de seus temas de importância menor, subjugando à história todo o conhecimento filosófico:

(...) for Croce, in this culminating phase of his thought, the task of philosophy is limited to thinking out the meaning of concepts which as actual functions of thought exist only as predicates of historical judgements. There is only one kind of judgement, the individual judgement of history. In other words, all reality is history and all knowledge is historical knowledge. Philosophy is only a constituent element within universal history; it is the universal element in a thought whose concrete being is individual. ${ }^{21}$

\footnotetext{
${ }^{19}$ A. Momigliano, Storia e storiografia antic,. Bologna: Il Mulino, 1987. pp. 7-8.

${ }^{20}$ R. G. Collingwood, The Idea of History, Oxford University Press, 1951, p. 196.

${ }^{21}$ Ibidem, p. 199.
} 
O historicismo croceano, nesses termos colocado, implica tanto o pensamento filosófico quanto o pensamento histórico (que em última instância não se distinguem entre si) como historicizáveis. Para Croce, toda a história verdadeira é história contemporânea, pois a história só é realmente história ao pressupor pensamento, e para tanto é necessário que o objeto de que se ocupa seja abordado a partir de um problema presente. $\mathrm{O}$ ato de se pensar um objeto histórico, por sua vez, implica re-elaborações que estejam de acordo com necessidades espirituais que dizem respeito ao presente, pois vida e história, no pensamento de Croce, são concebidas como unidade, e vida pressupõe envolvimento espiritual. $^{22}$

O regime de historicidade a que estão submetidos os conceitos filosóficos empregados no pensamento histórico, ou seja, o âmbito individual necessariamente contido nos juízos universais que são filosofia, implica a impossibilidade de uma solução definitiva para os problemas históricos, de forma que cada solução proposta para cada problema individual dá origem a novos problemas, num ciclo sucessivo de problemas-soluções: persuadi-los

There is progress in the sense that each action is internally a concrescent progress from an initial problem to an eventual solution, and each new problem-solution builds upon the foundations of the old. But there is no solution which dissolves all problems. Without obstacles there can be no life: becoming is inescapably a tale of struggle, of conflict, of the dialectic between inheritance (being) and possibility (nonbeing). There is a teleology in each action toward optimal outcome but no telos to the universe as a whole, and no optimal outcome überhaupt. ${ }^{23}$

Diante disso, um progresso da historiografia em termos de ampliação do questionário e enriquecimento da cultura histórica, como propõe Paul Veyne, ${ }^{24}$ é por Croce previsto. Ainda que jamais aponte para uma solução definitiva, a contínua renovação dos problemas históricos implica um aumento do número de conceitos e categorias de que dispõe o historiador e, conseqüentemente, um maior número de questões que poderá levantar a respeito de seu objeto. Dessa forma, Croce afirma que a historiografia...

(...) has certainly accomplished some progress since the days of Diogenes of Halicarnassus and of Cicero to those of Hegel and of Humboldt. Other problems have been formed in our own day, some of which I attempt to solve

\footnotetext{
${ }^{22}$ Ibidem, pp. 12-14.

${ }^{23}$ George Allan, “Croce and Whitehead on Concrescence”, in: Process Studies, Vol. 2, Number 2, Summer, 1972, p. 97.

${ }^{24}$ Paul Veyne, Como se escreve a história, Brasília: Ed. Universidade de Brasília, 1992, p. 105.
} 
in this book. I am well aware that it affords solutions only to some among the many, and especially that it does not solve (simply because it cannot) those that are not yet formed, but which will inevitably be formed in the future. ${ }^{25}$

A implicação inevitável desse processo é a consciência de sua historicidade, ou seja, a consciência de que a produção historiográfica tem uma história:

Returning to and remaining in or moving in the concrete fact, or, rather, making of oneself thought that thinks the fact concretely, we experience the continual formation and the continual progress of our historical thought and also make clear to ourselves the history of historiography, which proceeds in the same manner. And we see how (I limit myself to this, in order not to allow the eye to wander too far) from the days of the Greeks to our own, historical understanding has always been enriching and deepening itself, not because abstract causes and transcendental ends of human things have ever been recovered, but only because an ever increasing consciousness of them has been acquired. Politics and morality, religion and philosophy and art, science and culture and economy, have become more complex concepts and at the same time better determined and unified both in themselves and with respect to the whole. Correlatively with this, the histories of these forms of activity have become ever more complex and more firmly united. ${ }^{26}$

Podemos identificar nas propostas teóricas de Croce elementos que justificam as formulações propostas por Momigliano relacionadas à história da historiografia. A premissa de que o entendimento do sentido que os historiadores do passado deram aos eventos que estudaram é indispensável para a compreensão da própria história, apresentada por Momigliano em sua conferência de 1940, encontra fundamento no pressuposto croceano de que os problemas históricos com que lidamos no presente derivam dos problemas dos historiadores do passado. Como Momigliano observaria décadas mais tarde, este foi o principal ensinamento de Croce que absorvera em sua juventude.

\section{III}

Se em meados da década de 1940, quando Momigliano anunciava o novo tema de sua pesquisa, a história da historiografia constituía um ramo marginal da pesquisa histórica, no início da década de 1980 temos uma situação diversa. Momigliano reclama, em artigo de 1981, de uma superprodução no campo da história da

\footnotetext{
${ }^{25}$ B. Croce, Theory and History of Historiography, London: George G. Harrap \& Co., 1921, p. 47.

${ }^{26}$ Ibidem, p. 77.
} 
historiografia, cuja proposta visava relativizar o valor das obras historiográficas em função de serem elas condicionadas pelas ideologias vigentes nas épocas de suas produções. ${ }^{27}$ Essa tendência vinha no encalço da abordagem do discurso historiográfico como metahistória, proposta por Hayden White no início dos anos 70, à qual Momigliano se opõe no artigo em questão. A discussão que propõe não tem como foco a abordagem de White em si, cujo pressuposto é de que a escrita da história, como qualquer outra forma de literatura, constrói a realidade por meio de modos específicos de discurso (metáfora, metonímia, sinédoque e ironia), cada qual implicando uma conceptualização própria da relação entre indivíduo e sociedade. O que interessava e preocupava Momigliano não era a proposta de White, mas sim as suas conseqüências. Nesse contexto temos outra premissa importante para a compreensão do pensamento histórico de Momigliano - a sua percepção de que a tarefa do historiador consiste, acima de tudo, em descobrir e estabelecer verdades:

(...) Why should I worry if a historian prefers presenting the part for the whole rather than the whole for the part? After all, I never worried if a historian chose to write in epic style or to introduce speeches into his account. I have no reason to prefer synecdochic to ironic historians or vice versa. But I have a good reason to distrust any historian who has nothing new to say or who produces novelties, either in fact or in interpretation, that I discover to be unreliable. Historians are supposed to be discoverers of truths. No doubt they must turn their research into some sort of story before being called historians. But their stories must be true stories. ${ }^{28}$

A conseqüência nefasta da abordagem de White identificada por Momigliano é justamente a eliminação da pesquisa pela verdade como a tarefa essencial do historiador. As idéias de que historiadores manipulam os dados com fins propagandísticos - sejam eles políticos, sociais ou religiosos -, de que tal manipulação é inevitável e mesmo saudável, e de que aqueles que acreditam que historiadores estão comprometidos com a verdade são enganadores e auto-enganadores, eram para Momigliano inaceitáveis. ${ }^{29}$ A questão lhe perturbou, sobretudo na última década de sua vida, de forma que diversos artigos a ela dedicados foram por ele redigidos entre $1974 \mathrm{e}$ 1985.

\footnotetext{
${ }^{27}$ A. Momigliano, "History of Rethorics and Rethorics of History", in: Settimo contributo alla storia degli studi classici e del mondo antico, Roma,Edizioni di Storia e Letteratura, 1984. p. 54.

${ }^{28}$ Ibidem, pp. 50-51.

${ }^{29}$ A. Momigliano, Settimo contributo alla storia degli studi classici e del mondo ântico, Roma, 1984, p. 254.
} 
Em 1982, no artigo Considerations on History in an Age of Ideologies, ${ }^{30}$ Momigliano propõe o ceticismo em relação à objetividade da história como resultado de uma demanda por diretrizes para o futuro da humanidade que a história não poderia oferecer. Tal demanda estaria relacionada ao emprego da história para fins educativos recente se comparada a outras disciplinas como a filosofia ou a matemática -, numa sociedade que pressupõe educação voltada para as massas e, sobretudo, para os jovens. Desde Heródoto até a sua recente incorporação ao sistema de ensino, a história havia sido voltada para um público adulto que nela encontrava interesses específicos. O historiador tinha em mente que dialogava com pessoas adultas cujas ações derivavam de critérios e convicções estabelecidos a partir de crenças religiosas, filosóficas e morais bem enraizadas. Ocorre que, diante do declínio da autoridade de doutrinas filosóficas, religiosas e morais (Momigliano não aponta as causas nem entra nos méritos desse declínio), tornou-se comum recorrer ao historiador em busca de respostas que eram anteriormente fornecidas por estas doutrinas.

A história pode, de acordo com Momigliano, fornecer conhecimento sobre o passado, que é condição útil, mas não suficiente para a ação. O reconhecimento da história como forma de retórica e sua implicação básica, uma abordagem da mesma de acordo com métodos da pesquisa retórica, no que consiste a proposta de White, é para Momigliano resultado de um abuso dos limites da história e do uso que dela se pode fazer. Diante dessa perspectiva, sugere que a história deve permanecer, mesmo em tempos de educação massiva, o que era quando escrita para um número limitado de adultos - informação sobre o passado estabelecida por meio de pesquisa histórica e com o pressuposto de um comprometimento com a verdade.

Momigliano já chamava atenção para o problema dos limites da história e de seu uso em um artigo anterior, Historicism Revisited, publicado em 1974 (ano seguinte à publicação da Metahistory de Hayden White), no qual chamava a atenção para a impossibilidade de se derivar juízos morais da história:

\footnotetext{
O possediamo una fede religiosa o morale, indipendente dalla storia, che ci permette di emettere giudizi sugli avvenimenti storici, oppure dobbiamo lasciar perdere il giudizio morale. Proprio perché la storia ci insegna quanti codici morali há avuto l'umanità, non possiamo derivare il giudizio morale dalla storia. Perfino la nozione del transformare la storia studiandola implica una fede metastorica. ${ }^{31}$
}

\footnotetext{
${ }^{30}$ Ibidem, pp. 253-269.

${ }^{31}$ A. Momigliano, Sui fondamenti della storia antica, Torino: Giulio Einaudi, 1984. p. 461.
} 
Sua posição frente ao dilema é clara:

Avendo comunque fatto, in questo dilemma, la mia scelta - avendo chioè deciso di usare il mio giudizio morale come segno della mia libertà di fronte alla storia - preferisco occuparmi degli aspetti tecnici e delle tendenze attuali della ricerca storica nell'età dello storicismo. ${ }^{32}$

Assim como o ensino de história em escolas, Momigliano nota que a história como disciplina acadêmica, ensinada em universidades, constitui um fenômeno relativamente recente. No artigo entitulado Introduction of History as an Academic Subject and its Implications, ${ }^{33}$ de 1985, o historiador propunha desenvolver o argumento apresentado no já abordado no artigo Considerations on History in an Age of Ideologies, oferecendo, para tanto, um quadro da lenta e tardia incorporação da história como disciplina independente ao curriculum das universidades européias. A abordagem parte do contexto do mundo antigo. Momigliano observa que obras históricas eram lidas publica e privadamente tanto na Grécia quanto em Roma, mas a história, porém, jamais viria a constituir objeto específico de instrução em escolas no decorrer da Antigüidade. Passando brevemente do mundo antigo à Idade Média e desta ao século XIII, quando as universidades se encontravam firmemente estabelecidas, não se identificam mudanças em relação ao status da história, que continuava não sendo considerada objeto apropriado para o ensino. Tampouco a penetração do humanismo italiano nas universidades, no século XV, significou uma mudança neste quadro.

Entre outros motivos pelos quais a história continuava mantida fora do curriculum, Momigliano chama a atenção para o fato de a história constituir um objeto pouco definido. Desde Antigüidade, as circunstâncias em que obras históricas eram escritas variavam e suas finalidades eram diversas. Uma única constante é identificada: ao historiador cabia dizer a verdade, a inclinação à mentira e à invenção não era admitida - nisto consiste um ponto recorrentemente enfatizado por Momigliano, que contestava a idéia da história como mero objeto da retórica no contexto do mundo antigo. Deste compromisso com a verdade, deriva um elemento de pesquisa, o qual estaria desde o início associado à história, mas que, entretanto, permanecia pouco definido, de forma que uma qualificação específica para se narrar eventos transcorridos

\footnotetext{
${ }^{32}$ Ibidem, pp. 461-2.

33 Arnaldo Momigliano, Ottavo contributo alla storia degli studi classici e del mondo antico, Roma, 1987, pp. 161-177.
} 
não era julgada necessária, assumia-se que qualquer pessoa educada poderia fazê-lo. As qualidades geralmente apreciadas em uma obra histórica, a clareza e a eloqüência da exposição, bom senso e princípios morais na análise dos eventos, podiam ser obtidas através do estudo de outras disciplinas - gramática, retórica, filosofia, religião -, de forma que a história "was not important enough to be taught, and that, even if it was important, it was not difficult enough to be taught". ${ }^{34}$

A mudança desta atitude frente à história constituiu um lento processo. Momigliano apresenta um complexo quadro da introdução da história no curriculum das universidades européias entre os séculos XVI e XIX, no qual destaca a importância da Alemanha, cuja situação no século XVI teria criado, por uma série de razões, as condições para a introdução da história no ensino. A definição da história como objeto, entretanto, não ocorreu sem ambigüidades e entraves. A difusão do método histórico alemão no século XIX é proposta por Momigliano não como uma repentina conseqüência do movimento romântico, mas como o ponto culminante de um processo que se estendeu pelos séculos anteriores. No contexto do século XIX, dois importantes desenvolvimentos são apontados: 1) a história se torna a forma pela qual a formação do mundo e do homem passa a ser vista, ganhando maior importância e autonomia; 2) com o surgimento de novas teorias sobre a origem do homem, do cristianismo, da arte e da literatura, surge a necessidade de um maior controle das evidências que comprovavam tais teorias. Deste segundo desenvolvimento resulta o surgimento de métodos de pesquisa histórica mais rigorosos, o de Ranke sendo apontado como apenas um dos dispositivos de disseminação da austeridade científica na análise da evidência.

Neste ponto, Momigliano faz uma importante distinção para a compreensão de sua forma de entender a história: à pesquisa histórica (historical research) contrapõe o pensamento histórico (historical thinking), observando uma interdependência e uma relação complexa entre uma e outro. Ao passo em que o controle da evidência tende a tornar-se um fim em di mesmo, Momigliano observa que o pensamento histórico mais ousado e interessante lhe nega grande importância: “Tocqueville, Karl Marx, Burckhardt, Fustel de Coulanges (at least in the Cité Antique) never treated evidence in a way to satisfy what Burckhardt called the 'viri eruditissimi'. Even Mommsen, of all people, wrote his Roman history without producing evidence”. ${ }^{35}$ A tensão entre

\footnotetext{
${ }^{34}$ Ibidem, p. 165.

${ }^{35}$ Ibidem, p. 177.
} 
generalizações históricas e estudo das fontes, recorrente no século XIX, teria sido herdada pelo século XX, e a aquisição da consciência desta tensão teria servido para intensificá-la. No presente, Momigliano observava uma assimetria entre pensamento e pesquisa históricos, que em termos docentes, traduzia da seguinte maneira: "the teacher seldom manages to keep a balance between thinking and reasearching. The teacher of history thinks more than he knows or knows more than he thinks”. ${ }^{36}$

Esta assimetria entre pensamento histórico e pesquisa histórica era, no artigo de 1982, identificada como conseqüência do uso da história como objeto de ensino, relacionada à ocorrência paralela de um desequilíbrio entre interpretação de fatos históricos e descoberta de novos fatos históricos. Nos cursos universitários, a interpretação de fatos antigos seria inevitavelmente mais freqüente que a descoberta de novos fatos, e apenas a descoberta de novos fatos, na compreensão de Momigliano, manteria o senso de que a história depende de evidências e de que a descoberta de novas evidências e fatos irá sempre colocar à prova as conclusões oferecidas.

\section{IV}

À associação comum entre história e retórica, Momigliano contrapunha em artigo de 1985, entitulado History between Medicine and Rethoric, ${ }^{37}$ uma associação mais obscura: aquela entre história e medicina. A influência da linguagem e experiência hipocrática em Túcidides, a colaboração entre Virchow e Schliemann em Tróia e o fato de os antiquários do século XVII haverem freqüentemente atuado também como médicos consistiriam, para Momigliano, episódios inseridos no contexto de uma colaboração mais ampla entre médicos e historiadores, no qual atenta para as similaridades entre os métodos de uns e de outros. Momigliano questiona o motivo pelo qual a história, nos períodos helenístico e romano, fora submetida à retórica e o mesmo não haver ocorrido com a medicina, a despeito das similaridades entre ambas. Ao desenvolver tal questão, Momigliano propõe uma revisão da idéia comum no presente de que a história fora, na Antiguidade, mero objeto da retórica. Os retóricos antigos (principalmente Cícero e Dionísio de Halicarnasso, os primeiros a propor uma

\footnotetext{
${ }^{36}$ Ibidem, p. 178.

${ }^{37}$ Ibidem, pp. 13-25.
} 
abordagem extensiva da história) ofereceriam apenas um tratamento parcial do problema da escrita da história, limitado ao estilo que melhor se adequaria à sua escrita. Ainda que reconhecessem a veracidade dos fatos narrados como premissa fundamental da escrita da história, não desenvolveram uma metodologia de pesquisa para o estabelecimento da verdade. Mesmo no tratado sobre a escrita da história de Luciano, no qual a ênfase recai sobre esta premissa da veracidade da narrativa, não há uma proposta de metodologia que vá além do que já havia sido proposto por Heródoto e Tucídides - o historiador deve dar preferência a depoimentos de testemunhas oculares dos eventos, apenas na ausência destes recorrendo a testemunhos indiretos. O que se tem no tratado de Luciano é o mesmo que encontramos nas abordagens propostas pelos demais retóricos da Antiguidade, ou seja, conselhos sobre estilo.

Os retóricos antigos desconsideravam a questão da verdade, ainda que a reconhecessem, por considerá-la, de acordo com Momigliano, fora do âmbito de sua competência. No contexto de suas abordagens, estava excluído o âmbito em que história e medicina se aproximavam em suas práticas: o da investigação. A mesma exclusão é denunciada por Momigliano no discurso daqueles que, no presente, propunham uma abordagem retórica da história. No artigo The Rethoric of History and the History of Rethoric ${ }^{38}$ de 1981, a questão colocada é justamente a eliminação da investigação histórica como conseqüência do tratamento da história como forma de retórica. Momigliano assinala no artigo a importância da evidência para o historiador, platitude indispensável da pesquisa histórica. Há, admite, subjetividade na escolha do objeto e nos problemas colocados pelo historiador; porém, uma vez definidos os objetos e problemas, o historiador deve se subordinar ipso facto ao que dizem as evidências que possui. Em outras palavras, o "pensamento histórico” deve, em princípio, ser submetido aos resultados da "pesquisa histórica”. O pensamento histórico não deve necessariamente estar confinado aos limites impostos pelas evidências, mas uma separação clara entre considerações ideológicas e pensamentos privados e aquilo que comprovam as evidências deve ser observada, pois é pelo uso que faz das evidências que o historiador será julgado. Com isso, Momigliano estabelece o controle da evidência como critério de avaliação objetiva da competência de historiadores tanto do presente quanto do passado. Em New Paths of Classicism in the Nineteenth Century,

\footnotetext{
${ }^{38}$ A. Momigliano, Settimo contributo alla storia degli studi classici e del mondo antico, Roma, 1984, pp. 48-59.
} 
artigo publicado em 1982, o estabelecimento desse critério é formulado nos seguintes termos:

In our time there is a great danger that those who talk most readily about historians and scholars may not know too much about history and scholarship. Housman's homosexuality or Wilamowitz's erratic behavior with his father'in'law Mommsen are easier to describe than Housman's achievements as an editor or Wilamowitz's understanding of Aeschylus. Equally it is easier to criticize Eduard Meyer's political pamphlets during the First World War than his analysis of the papyri of Elephantine or of Egyptian chronology. Though it would be a pity to forget those imponderable elements of a scholar's personality which are his hidden strength or weakness, we have to shift discussion toward specific scholarly achievements if we want to avoid the danger of superficial and partisan evaluations. The fact that Georges Dumézil was, we are told, a supporter of the Action française is not an argument against his theories on Indo-European society. In an age of ideologies, we must be increasingly careful to submit scholarly results to the sole legitimate criterion of evaluation, which is the reliability of the evidence. ${ }^{39}$

Retomando o artigo Historicism Revisited, de 1974, ponto de partida do diálogo que Momigliano estabelece com as tendências retóricas que então surgiam no âmbito dos estudos históricos, a raiz da questão é identificada no problema do historicismo e suas implicações. O reconhecimento de que o historiador não é um agente externo à história, mas vê os acontecimentos passados de um ponto de vista determinado ou ao menos condicionado por sua situação singular e mutável dentro da história, traz como conseqüência um risco de relativismo. É justamente neste relativismo que recaem as obras de história da historiografia a que Momigliano se refere ironicamente, no início da década de 1980, como "all these dear little dissertations on Baronio, Gibbon, Renan and Grote,” escritas por historiadores que considera inaptos para tal trabalho, "people who would not be able to translate any of texts which those historians controlled." 40 Para Momigliano, a finalidade do estudo da história da historiografia passa longe de qualquer proposta de relativismo:

L'inevitabile corollario dello storicismo è la storia della storiografia, come modo di esprimire la consapevolezza che i problemi sotici hanno essi stessi una storia. Ciò ha però prodotto libri il cui solo scopo è di dimostrare che ogni storico e ogni problema storico è storicamente condizzionato - con la banalità aggiuntiva che perfino un verdetto di questo tipo da parte dello storico della storiografia è storicamente condizionato.

\footnotetext{
39 A. Momigliano, A.D. Momigliano: Studies on Modern Scholarship, Ed. G.W. Bowersock and T.J. Cornell. University of California Press, 1994. p.223

${ }^{40}$ A. Momigliano, Settimo contributo alla storia degli studi classici e del mondo ântico, Roma, Edizioni di Storia e Letteratura, 1984. p. 54-55.
} 
Una tale espressione di relativismo, a mio giudizio, è indifendibile. La storia della storiografia, come ogni altra ricerca storica, ha loscopo di discriminare tra vero e falso. In quanto tipo di storia intellettuale che pretende di esaminare i risultati conseguiti da uno storico, essa deve distinguire fra soluzioni di problmi storici che non convincono e soluzioni (=ipotesi; modelli; tipi ideali) che meritano di essere riformulate e sviluppare. Per scrivere uma storia critica della la storiografia bisogna conoscere tanto gli autori che si studiano quanto il materiale storico che quegli autori hanno studiato ${ }^{41}$.

Assim, no que diz respeito às suas finalidades, história e história da historiografia se confundem, ambas visando, em última instância, o estabelecimento da verdade. A história da historiografia oferece a possibilidade de um refinamento dos métodos de estabelecimento da verdade em história através do exame dos métodos empregados por historiadores de gerações anteriores. Nesse sentido, o pensamento de Momigliano pressupõe a premissa de um progresso na produção historiográfica que remete àquele concebido por Croce. O progresso nos termos colocados por Momigliano, entretanto, além de um enriquecimento da cultura histórica em termos de ampliação do questionário, tal qual propuseram Croce e Veyne, implica igualmente o desenvolvimento progressivo de uma maior perspicácia por parte do historiador, que, munido das ferramentas utilizadas com sucesso por seus antecessores, se torna mais apto a descobrir e estabelecer a verdade sobre o passado. Neste contexto, é relevante a idéia da apropriação dos métodos antiquários pelos historiados, proposta por Momigliano no artigo Ancient History and the Antiquarian (1950), como será visto mais adiante.

\section{$\mathbf{V}$}

Ainda que Momigliano derive da filosofia de Croce a premissa básica de seu pensamento sobre a história da historiografia, há uma diferença marcante entre as concepções de um e de outro no que diz respeito ao tema. Para Croce, a avaliação de determinada obra historiográfica deve ser realizada unicamente em função de seu mérito histórico, ou seja, do valor das reflexões nela contidas, já que, de acordo com Croce, a história é constituída pelos atos de compreender e entender, induzidos pelos requerimentos da vida prática. De forma muito diferente do que concebe Momigliano, a veracidade dos fatos contidos em uma obra tem importância secundária para a avaliação

\footnotetext{
${ }^{41}$ A. Momigliano, Sui fondamenti della storia antica, Torino: Giulio Einaudi editore, p. 464.
} 
de Croce, uma vez que uma obra que contém verdades sem conter reflexão não é história, mas crônica. O pressuposto básico de toda a obra histórica é a reflexão, busca pela compreensão - ou "pensamento histórico", na terminologia de Momigliano; satisfeito tal pressuposto tem-se uma obra histórica, independente de trabalhar ela com fatos ou fábulas. A veracidade, para Croce, constitui uma qualidade desejável nas obras históricas, mas apenas com fins de legitimação perante possíveis detratores:

(...) no ha de ser juzgada una obra historica por el mayor o menor número y veracidad de los hechos que contenga, aunque solo fuera por la evidente razón de que son colecciones de hechos, muy copiosas y veraces, sin ser claramente historias, y otras, brillantes de entendimento historico, pero pobremente equipadas en quanto a información, o aun sembradas de hechos inseguros, legendarios o fabulosos. (...) Es, ciertamente, deseable que los hechos aducidos em una obra de historia se hayan comprobado cuidadosamente, aunque sólo sea para privar a los pedantes de una arma que insidiosamente y no sin éxito emplean para desacreditar escritos históricos vigorosos y genuinos. ${ }^{42}$

Momigliano obviamente não ignorava as diferenças entre a posição que defendia e os pressupostos da filosofia croceana, discutindo-as em seu artigo de 1984 sobre história e retórica. ${ }^{43}$ Da eliminação da barreira entre história e filosofia, observa, Croce teria derivado a teoria de que, em qualquer momento dado, qualquer mente humana possuiria toda a evidência que necessita, pois não há, para ele, diferença entre a Mente, que é o Espírito universal, absoluto e onipresente, capaz de produzir por si mesmo toda a evidência necessária, e a mente do indivíduo mortal. Sua teoria da historiografia, diante disso, não considera as limitações impostas pela evidência ao conhecimento histórico, fundamentais para a forma como Momigliano pensa a história. Este preceito filosófico de Croce, entretanto, não afetou, de acordo com Momigliano, sua obra propriamente historiográfica - ao menos em sua maior parte. Ignorar a evidência não era uma característica de Croce: ele era, por instinto, um estudioso da evidência. Sua trilogia sobre a contra-reforma na Itália e sua história da Itália após 1870 constituíam, de acordo com Momigliano, "rochas sólidas de fatos"; os fatos se tornam raros, entretanto, na sua história filosófica do liberalismo europeu no século XIX.

Momigliano alerta que a posição defendida de Croce não justifica a abordagem proposta de White e não deve ser com ela confundida. Pois White não cria em um Espírito universal capaz de produzir toda a evidência que o historiador necessita. Da

\footnotetext{
${ }^{42}$ B. Croce, La Historia como Hazaña de la Libertad, Mexico: Fondo de Cultura Exonómica, 1960, p.8.

${ }^{43}$ A. Momigliano, Settimo contributo alla storia degli studi classici e del mondo antico, Roma,Edizioni di Storia e Letteratura, 1984. p. 55.
} 
mesma forma que "nós" (no que Momigliano se inclui), White não está certo da racionalidade da realidade, ele antevê o caos - e, de acordo com Momigliano, diante do caos o uso da evidência se faz ainda mais indispensável. ${ }^{44}$ Croce acreditava que o historiador teria disponível toda a evidência que necessitasse sempre que necessitasse; para a abordagem de White, a evidência sequer constitui um elemento relevante para o processo de escrita da história.

A despeito da influência e importância da filosofia de Croce para o desenvolvimento de seu pensamento histórico, Momigliano jamais se caracterizou como um adepto da filosofia croceana - ou de qualquer doutrina filosófica. "Momigliano era filosoficamente meglio armato di ogni altro storico italiano di quell'età. (...) Ma non era, ne voleva essere, um filosofo," Arnaldo Momigliano e Croce, Dionisotti questiona os motivos que levaram Croce a escolher Momigliano para a direção de seu Istituto Storico e os motivos que levaram o último a recusar o convite. Na carta enviada a Croce, Momigliano apontava como principal motivo para a recusa seu despreparo e incompetência nos campos da história medieval e moderna e sua conseqüente inabilidade para orientar pesquisas nesses campos. Em carta ao amigo Dionisitti, comentando sua decisão, Momigliano colocava que não se sentia inclinado a tomar para si a responsabilidade de um instituto que devesse dar continuidade à obra de Croce - um instituto de história moderna, inevitavelmente. Se havia motivos diversos além destes explicitados nas cartas de Momigliano, Dionisotti considera uma questão difícil de ser respondida. Destaca, entretanto, os pontos em que Croce e Momigliano diferiam em suas apreciações, entre os quais destaca a (in)distinção entre filosofia e história:

Il rapporto tra filologia e storia da una parte, tra filosofia e storia dall'altra, sempre era stato per Momigliano diverso da quel che era per Croce e per i suoi allievi. A Oxford, per la prima volta si era trovato a vivere e lavorare in un ambiente, in cui il rapporto fra storia antica e filologia era piú stretto che in Italia, e in cui storia, qualunque storia, e filosofia erano discipline rigorosamente distinte. Da buon italiano e da buon crociano, Momigliano aveva reagito polemicamente alla distinzione. Ma anche aveva sentito sempre piú il peso, il dastidio e la vegogna di certa tradizione retorica italiana, di certa critica e storia in cui l'abbondanza delle chiacchiere filosofico-letterarie mascherava l'ignoranza e la presunzione. A nessun costo voleva ridiscendere a quel livello, ritrovarsi a gareggiare in quell' arena. ${ }^{46}$

\footnotetext{
${ }^{44}$ Ibidem, p. 56.

${ }^{45}$ C. Dionisotti, “Momigliano e Croce”, in: Belfagor, 43, 1989, p. 640.

${ }^{46}$ C. Dionisotti, op. cit., pp. 640-1.
} 
Segundo Oswyn Murray, as origens do pensamento de Momigliano a respeito da história da historiografia remeteriam a uma variedade de influências, nenhuma delas decisiva. ${ }^{47}$ Ao propor tal coisa, Murray trabalha com a idéia de que os anos em Oxford entre 1939 e 1946, nos quais Momigliano esteve em contato com eruditos humanistas de toda a Europa, teriam sido decisivos para os rumos que tomaria sua pesquisa e produção a partir daquele período. Sinais da experiência da guerra e do exílio são, de acordo com Murray, difíceis de serem encontrados na obra de outros refugiados, principalmente os alemães; na obra de Momigliano, o único italiano a integrar o grupo centrado no Ashmolean Museum em Oxford e também o mais jovem entre eles, o impacto teria sido profundo:

It is surely this experience of daily contact with the greatest scholarship of Europe in a context of pure research, which turned him from the learned but orthodox Italian ancient historian into the European polymath, who took the whole classical tradition as his domain. ${ }^{48}$

Murray acredita que a experiência de Momigliano no período em questão teria sido fundamental para que este deixasse de ser um historiador tradicional da antiguidade e se tornasse um polímata cujo direcionamento era ainda incerto, mas apontava para fora dos limites estabelecidos pela disciplina. O estudo da história antiga na Inglaterra era na época confinado a certos períodos e problemas aos quais os historiadores deveriam se enquadrar, suas fontes se limitavam a documentos textuais - literários ou epigráficos -, e seu campo ao da história política e militar. Apenas os historiadores marxistas e os arqueólogos ofereciam abordagens alternativas. Nesse sentido, tanto Murray quanto François Hartog apontam Moses Finley e Arnaldo Momigliano como principais responsáveis pelo rompimento destas convenções:

(...) intelectuais certamente diferentes, mas que possuem em comum competências e interesses que ultrapassam em muito os estudos clássicos; (...) historiadores que, arriscando às vezes passarem por excêntricos em sua própria disciplina, tiveram sempre a preocupação de manter contato com especialistas de outros períodos ou de outras ciências sociais." 49

A despeito dos novos rumos que a produção de Momigliano viria a tomar a partir de meados da década de 1940, Murray admite que a metodologia de Momigliano

\footnotetext{
47 Oswyn Murray, “Arnaldo Momigliano in England”, In: History and Theory, vol. XXX, n.4, Beiheft 30, 1991, p. 54.

${ }^{48}$ Ibidem, p.53.

${ }^{49}$ François Hartog, Os antigos, o passado e o presente, Brasília: Universidade de Brasília, 2003. p. 66.
} 
manteve-se em grande medida inalterada no decorrer de toda a sua produção. Sua origem remete à juventude do historiador, situando-se na erudição italiana e na tradição filosófica de Croce, combinadas com um respeito filológico pela evidência, herdado da tradição positivista alemã. Ainda que o foco da atenção de Momigliano tenha se deslocado no decorrer dos anos, Murray percebe, como já apontado, que os temas que mais tarde ganhariam importância no contexto de sua obra encontram-se com freqüência pré-figurados na sua produção anterior ao exílio, nos escritos de sua juventude na Itália. Diante disso, admite a possibilidade de exagerar a extensão das influências externas sobre os rumos da obra de Momigliano ao propor o período em Oxford como decisivo para o estabelecimento dos mesmos. ${ }^{50}$

No que diz respeito à relação com Croce e sua filosofia, Murray propõe uma identificação progressiva da parte de Momigliano, cujo ápice teria sido atingido em seus ensaios tardios:

So, despite his deep appreciation of the teaching of De Sanctis, he came more and more to see himself as a disciple of a man whom he had known personally and from his writings, Benedetto Croce. Croce was indeed the dominant intellectual force in the Italy of his youth; but what is remarkable is the increasing identification with Croce and his view of history in Momigliano's later essays. This was no adherence to a theory (he mistrusted all general theories of history), but a growing recognition that Croce provided the justification for his view of history. ${ }^{51}$

O reconhecimento da importância de Croce para a sua forma de pensar a história aparece de forma explícita, como vimos, em textos dos últimos anos de Momigliano, sobretudo em prefácios para compilações de seus artigos. Não há evidência, entretanto, de que o pensamento de Momigliano tenha se desenvolvido paralelamente, desvinculado das teorias de Croce, e que uma identificação posterior com tais teorias tenha resultado no reconhecimento das mesmas, como propõe Murray. Pelo contrário, as teorias de Croce parecem estar na origem da forma como Momigliano concebe a história. Isto não implica que Momigliano possa ser caracterizado em qualquer momento como um adepto da filosofia croceana, mas sim que sua forma particular de pensar a história surge de seu contato com esta filosofia, dela derivando. Neste sentido, em seu artigo Momigliano and De Martino, Carlo Ginzburg identifica na obra de ambos

\footnotetext{
50 Oswyn Murray, “Arnaldo Momigliano in England”, in: History and Theory, vol. XXX, n.4, Beiheft 30, 1991. p. 62.

51 Oswyn Murray, “Arnaldo Momigliano (1908-1987)”, in: The Journal of Roman Studies, Vol. 77. (1987), pp. xi-xii.
} 
estes intelectuais linhas paralelas que divergem, de maneira distinta entre si, da tradição do historicismo croceano. ${ }^{52} \mathrm{O}$ abandono da filosofia de Croce, no caso de De Martino, teria significado a opção por um historicismo mais radical, imune em relação a limitações etnocêntricas, ao passo que para Momigliano tornara-se progressivamente claro, com o passar dos anos, que toda e qualquer forma de historicismo era inaceitável por implicar ameaça de relativismo. ${ }^{53}$

A relação entre Momigliano e Croce durante a década de 1930 e a reaproximação de ambos em meados da década de 1940, sobretudo com a visita de Momigliano a Nápole e sua estadia na casa de Croce em 1946, seguida do convite para a direção do Istituto storico - isso justamente no ano em que Momigliano anunciava seu novo tema de pesquisa e publicava o artigo sobre Creuzer, possivelmente logo após sua viagem à Itália -, apontam para uma possível influência da filosofia de Croce sobre o seu pensamento no período. O discurso de Momigliano sobre a importância da história da historiografia na conferência de 1940, logo no início de seu exílio, além de ecoar claramente pressupostos da filosofia croceana, deixa claro que a formulação de suas idéias a respeito do tema e a consciência de sua importância datam de um período anterior ao exílio. O impacto dos anos de convívio com intelectuais de toda a Europa em Oxford no período entre 1939 e 1946 sobre o pensamento de Momigliano, para o qual Murray chama a atenção, não deve, obviamente, ser desconsiderado. Este impacto não deve ser medido, entretanto, em relação aos temas pré-figurados na sua produção de períodos anteriores, mas sim em relação à forma como estes temas foram desenvolvidos no contexto em que ganham maior destaque e aos problemas aos quais aparecem relacionados em suas novas figurações.

\section{VI}

Logo no início de seu exílio na Inglaterra, ainda em 1939, Arnaldo Momigliano estabelecia, em Londres, um importante vínculo com Fritz Saxl e com o Warburg Institute. Com a ascensão do nazismo na Alemanha, o Warburg Institute, originalmente

\footnotetext{
${ }^{52}$ Carlo Ginzburg, "Momigliano and De Martino", in: History and Theory, vol. XXX, n.4, Beiheft 30, 1991. p. 37.

${ }^{53}$ Ibidem, p. 48.
} 
sediado em Hamburgo, fora transferido para Londres no ano de 1934, tornando-se ali um refúgio para intelectuais exilados. ${ }^{54}$ Saxl, diretor do instituto e responsável pela sua transferência para Londres, teve, de acordo com Anthony Grafton, um importante papel no desenvolvimento do estilo de escrita de Momigliano em seus artigos de língua inglesa, ${ }^{55}$ dos quais alguns dos mais celebrados figuraram nas páginas do Journal of the Warburg and Courtauld Institutes, entre eles o já aludido artigo sobre Friedrich Creuzer, de 1946, e o artigo Ancient Historian and the Antiquarian, de 1950.

O ceticismo em relação à capacidade do historiador de estabelecer a verdade e a identificação da história como forma de retórica, questões que, como visto, preocuparam Momigliano a partir da metade da década de 1970, não eram por ele identificadas como um problema inteiramente novo. A associação entre história e retórica, como observou no artigo Considerations on History in an Age of Ideologies, ${ }^{56}$ já era discutida na escola de Isócrates no IV século a.C., quando, assim como no presente, a história estivera na iminência de ser absorvida por completo pela retórica. Da mesma forma, o século XVII vivenciara um clima de absoluto ceticismo em relação à objetividade da história, o qual Momigliano identifica como uma “doença”. Assim, a superação desta crise pela qual passava a história ocorreria da forma como as doenças são normalmente curadas, ou seja, com a descoberta de um novo remédio. Estando as histórias e crônicas desacreditadas, os antiquários se voltaram para moedas, inscrições e escrituras, oferecendo novas e melhores evidências, nas quais Momigliano identifica o remédio que, naquele contexto, pôs um fim ao ceticismo em relação à história - o mesmo ceticismo que no presente voltava a se manifestar.

Esta crise da história no século XVII, seus desdobramentos e seu impacto sobre o método histórico nos séculos que se seguiram são abordados por Momigliano em seu artigo sobre os antiquários de 1950, publicado no Journal of the Warburg and Courtauld Institutes. Neste artigo, Momigliano identifica uma cisão da história em dois gêneros distintos: o primeiro, tido como "história” propriamente, constituía a narrativa de eventos políticos organizados de forma linear e causal, enquanto o segundo -

\footnotetext{
${ }^{54}$ Como observado por Oswyn Murray em O. Murray, “Arnaldo Momigliano in England”, in: History and Theory, vol. XXX, n.4, Beiheft 30, 1991, p. 56.

${ }^{55}$ Anthony Grafton, "Momigliano at the Warburg: the origins of a style", in: American Scholar, vol. 73, n. 4, 22 September 2004, pp.129-133.

${ }^{56}$ A. Momigliano, Settimo contributo alla storia degli studi classici e del mondo antico, Roma, 1984, pp. 253-269.
} 
chamado antiquitates - propunha uma apresentação sistemática que priorizava a etnografia, a biografia, a religião, a economia e a arte em detrimento da narrativa política. Momigliano identifica o início desta cisão com o profundo impacto da obra de Tucídides sobre a escrita da história. Segundo ele, a mais importante realização de Tucídides fora ter convencido seus sucessores de que a história é a história política, de forma que aquilo que se encontrava fora do âmbito desta tornou-se campo da erudição, vindo a constituir o campo de interesse dos antiquários. ${ }^{57}$

Um breve histórico dos estudos antiquários é no artigo em questão apresentado, de suas origens - que Momigliano identifica entre aqueles que, na Grécia do V século a. C., ocupavam-se de compilar genealogias de homens e heróis, as tradições sobre as fundações das cidades e a lista de seus magistrados epônimos - ao século XVII, passando brevemente pelas principais obras e desenvolvimentos ocorridos no período helenístico, romano, a Idade Média e o Renascimento, para em seguida deter-se no que Momigliano intitula "a controvérsia dos séculos XVII e XVIII sobre o valor da evidência histórica.” Com as disputas religiosas e políticas do século XVII e o uso da história como ferramenta propagandística, o vínculo entre história e verdade é rompido, o que resultou no descrédito dos historiadores e em um ceticismo absoluto em relação à história. Este ceticismo, que recaía principalmente sobre as evidências literárias, tomou forma no Pirronismo histórico.

A atitude cética prevalecia, mas, como observou Momigliano, o ceticismo nem sempre implicava completo pessimismo em relação a um conhecimento histórico saudável. Determinar as características do que se podia considerar evidência confiável tornou-se, então, a meta de diversos tipos de estudiosos. O Pirronismo histórico atacava ao mesmo tempo o ensino tradicional da história e as crenças religiosas tradicionais, de forma que membros de congregações religiosas fizeram grandes esforços para estabelecer uma distinção entre desconfianças razoáveis e desconfianças não-razoáveis em relação à evidência histórica. Também as universidades protestantes alemãs se juntaram ao debate sobre o Pirronismo. Das mãos de historiadores e filósofos, a

\footnotetext{
${ }^{57}$ A breve passagem sobre a origem da distinção entre história e antigüidades no texto de 1950 apresenta o ponto de partida para a discussão sobre "a tradição herodoteana e a tradição tucidideana", tema de uma das leituras apresentadas sob o título de The Classical Roots of Modern Historiography no início da década seguinte. Aqui, Momigliano apresenta um quadro da influência de Tucídides sobre seus sucessores da Antigüidade ao século XIX, contrapondo as apreciações de sua obra em relação às de outros historiadores clássico, sobretudo Heródoto.
} 
controvérsia passava para as mãos de legistas, que, tradicionalmente preocupados com a confiabilidade dos testemunhos, podiam com sua experiência contribuir para o debate.

Como resposta à questão da confiabilidade das evidências, surge uma distinção entre evidência literária e evidência de outras espécies, tais como escrituras, declarações públicas, moedas, inscrições e estátuas. Estando as evidências do primeiro tipo desacreditadas, assumia-se o segundo tipo de evidência como mais confiável, de forma que o valor da história passava a depender em grande medida da quantidade de documentos públicos, inscrições e moedas examinadas pelos historiadores. A comparação entre evidência literária e não-literária passa a constituir critério ortodoxo contra o Pirronismo histórico.

Assim, a historiografia do final do século XVII e início do século XVIII se caracterizou pelo grande número de historiadores preocupados em averiguar a verdade de cada evento a partir dos melhores métodos de pesquisa. Esta era uma preocupação comum entre historiadores e antiquários, e os métodos utilizados por uns e por outros com freqüência coincidiam. Ainda que as diferenças entre obras de história e de antiquitates permanecessem claras, seus objetivos eram os mesmos, em ambos os casos buscava-se a verdade factual, não uma interpretação das causas e exames das conseqüências. Este quadro foi afetado no momento em que a erudição se tornou alvo de ataques de um novo tipo de historiador, o historiador “filosófico”, e os antiquários e historiadores eruditos passaram a perder seu prestígio.

Os historiadores filosóficos - Momigliano destaca, entre eles, Montesquieu e Voltaire - propunham uma nova abordagem, uma história que partisse de questões do presente, questões que diziam respeito ao desenvolvimento geral da humanidade, para as quais a exatidão dos detalhes não tinha relevância e as fontes literárias ofereciam respostas melhores que os artefatos dos antiquários. O tema central desta abordagem era a idéia de civilização e a história política estava a ela subordinada. Áreas que não interessavam ao historiador político comum e que até então os antiquários haviam reivindicado para si sem serem perturbados - a arte, a religião, os costumes, as instituições - constituíam questões de interesse dos historiadores filosóficos, ainda que o tratamento dado a elas pelos últimos fosse bastante diferente, assim como os fins que perseguiam.

Ainda que a erudição dos antiquários fosse considerada inútil pelos historiadores filosóficos, os estudos antiquários atravessaram o século XVIII sem que o direito de sua 
existência fosse colocado em dúvida. Foi no final deste século, entretanto, que as coisas mudaram de figura, quando, graças principalmente a Winckelmann e Gibbon, ficou evidente que erudição e filosofia não eram incompatíveis. Este ponto, tocado de maneira breve no artigo de 1950, seria desenvolvido por Momigliano em seguida em um artigo de 1952, publicado sob o título Gibbon's Contribution to Historical Method. ${ }^{58}$ Nele, Momigliano ambienta o leitor no contexto do conflito instaurado em meados do século XVIII entre o método histórico dos érudits ou antiquários e a abordagem dos historiadores filosóficos, contexto no qual Gibbon emerge como uma figura ambivalente, responsável pela conciliação de dois métodos de escrita da história que pareciam inevitavelmente opostos. Esta combinação entre filosofia e erudição, entre “pensamento histórico” e “pesquisa histórica”, Momigliano identifica como um ideal perseguido por muitos dos melhores historiadores do século XIX e também por muitos historiadores de seu próprio tempo. Constituía certamente um ideal que Momigliano nutria para si mesmo e uma posição que consciente ou inconscientemente lhe acompanhara desde o tempo de sua formação entre a erudição de seu maestro Gaetano De Sanctis e a filosofia de seu maestro Benedetto Croce, como percebeu Carlo Dionisotti: "i precedenti e strumenti della ricerca sua, estranei a Croce, erano quelli della disciplina in cui De Sanctis era maestro, ma i criteri e i fini della ricerca corrispondevano alla dottrina filosofica di Croce piottosto che alla fede di De Sanctis." 59 Este ideal, como visto, Momigliano identificava no historiador inglês George Grote, cuja grande distinção, propunha em sua leitura inaugural para a University College London, em 1950, era haver reunido, a exemplo de Gibbon, as características do erudito com as do historiador filosófico. Ao seu profundo respeito pela evidência, Grote associava a paixão pelas questões morais e seus interesses políticos, e isto mantinha sua obra relevante mais de um século após sua composição. ${ }^{60}$

A assertiva de Gibbon em relação à longevidade do Império Romano é por Momigliano adaptada para o contexto dos estudos antiquários no século XIX - a questão que se deve perguntar, de acordo com o último, não é por que os estudos antiquários foram destituídos de seu crédito no século em questão, mas sim como puderam sobreviver tão longe. De acordo com Momigliano, já não havia então espaço

\footnotetext{
${ }^{58}$ A. Momigliano, Contributo alla storia degli studi classici, Roma, 1955, pp. 195-211.

${ }^{59}$ C. Dionisotti, op. cit., p. 619.

${ }^{60}$ A. Momigliano, "George Grote and the Study of Greek History", in: A.D. Momigliano: Studies in Modern Scholarship. University of California Press, Berkley, 1994, pp. 15-31.
} 
para o afeto do antiquário pela classificação e pelo detalhe irrelevante quando "a new notion, both exacting and comprehensive, of human development left little space for mere description of the past”. ${ }^{6}$

\section{VII}

Diferentes temas podem ser identificados na produção de Arnaldo Momigliano no decorrer de sua trajetória acadêmica. Oswyn Murray, em seu ensaio Momigliano in England, ${ }^{62}$ destaca três grandes temas que teriam norteado a pesquisa do historiador durante suas primeiras décadas de exílio (de 1939 a 1970), sendo eles: a história da Antigüidade tardia, a história da historiografia e as origens de Roma.

A origem do interesse de Momigliano pela história da Roma arcaica, a exemplo da maior parte dos temas que seriam desenvolvidos pelo historiador durante o seu exílio na Inglaterra, remete ao início de seus estudos na Itália, na década de 1930. O tema das origens de Roma viria a figurar como uma das mais importantes preocupações de Momigliano principalmente na década de 1960, no decorrer da qual a maior parte dos de seus principais estudos a ele relacionados seriam desenvolvidos e publicados. A intensa produção desta década, como apontou Tim Cornell em seu artigo Momigliano and the Origins of Rome, contrasta com a escassez de estudos relacionados ao tema no período anterior e, sobretudo, no período posterior - a partir da década de 1970 o foco da pesquisa de Momigliano se desloca e nas décadas que se seguiriam questões relacionadas às origens de Roma seriam por ele tocadas apenas indiretamente, em artigos sobre estudiosos modernos - sua crítica do trabalho de Georges Dumézil e sua investigação dos trabalhos de Niebuhr, Max Weber, Bachofen e Fustel de Coulanges. Cornell identifica na crescente desconfiança de Momigliano em relação aos métodos dos arqueólogos a partir da década de 1970 o principal motivo de seu afastamento em relação ao tema. ${ }^{63}$ É relevante notar que, dentre os três grandes temas de interesse de Momigliano apontados por Murray, o estudo das origens de Roma teria tido, de acordo

\footnotetext{
${ }^{61}$ A. Momigliano. Contributo alla storia degli studi classici, Roma, 1955, p. 100.

62 O. Murray, "Momigliano in England”, in History and Theory, vol. XXX, n.4, Beiheft 30, 1991, p. 57.

63 Tim Cornell, "Momigliano and the Origins of Rome” in: Leando Polverini (org.), Arnaldo Momigliano nella storiografia del novecento, Edizioni di storia e letteratura, Roma, 2006, pp. 181-198.
} 
com o autor, o menor impacto sobre os estudos clássicos na Inglaterra em função de constituir um campo bastante dependente da arqueologia, o estudo das origens de Roma encontraria seu lar natural na Itália.

Os estudos sobre a Antigüidade tardia, por sua vez, teriam penetrado com maior êxito o meio acadêmico britânico. O interesse de Syme pelo tema a partir da década de 1960 e o importante estudo de A. H. M. Jones de $1964^{64}$ - assumidos como desvinculados da pesquisa de Momigliano, levam Murray a propor que o interesse pela Antigüidade tardia eventualmente emergiria na Inglaterra independentemente da contribuição de Momigliano. Este, porém, é creditado como o inaugurador dos estudos sobre o período no mundo de língua inglesa. A origem do interesse de Momigliano pelo período é identificada por Murray com os estudos sobre o cristianismo de Sêneca, ${ }^{65}$ que remeteria à influência da erudição italiana da juventude do historiador. Os estudos relacionados ao tema podem ser identificados, em grande medida, com os resultados da pesquisa de Momigliano sobre a paz e a liberdade no mundo antigo, iniciada na Itália e conduzida pelo historiador no decorrer dos seis primeiros anos de exílio, cujos principais desenvolvimentos até meados da década de 1940 foram discutidos no primeiro capítulo desta dissertação. Os estudos sobre os pensamentos de Tácito e Sêneca realizados no final da década de 1940 e início da década de 1950 (o artigo sobre Sêneca sendo mencionado por Murray como ponto de partida dos estudos de Momigliano sobre a Antigüidade tardia), ${ }^{66}$ são identificados por Riccardo Di Donato como fragmentos do projeto unitário de estudo da paz e liberdade no mundo antigo de Homero a Santo Agostinho apresentado por Momigliano à Oxford Clarendon Press no início de seu exílio na Inglaterra ${ }^{67}$ - projeto cuja inviabilidade fora progressivamente

\footnotetext{
${ }^{64}$ A. H. M. Jones, The Later Roman Empire, 1964

${ }^{65}$ Referindo-se ao artigo Note sulla leggenda Del Cristianesimo di Seneca, de 1950, reimpresso em A. Momigliano, Contributo alla storia degli studi classici, Roma: Edizioni di storia e letteratura, 1955, pp. 13-32.

${ }^{66}$ Os estudos sobre Tácito consistem no artigo "The First Political Commentary on Tacitus", de 1947, reimpresso em A. Momigliano, Contributo alla storia degli studi classici, Roma: Edizioni di storia e letteratura, 1955, pp. 37-59; e o capítulo "Tacitus and the Tacitist Tradition" das Sather Lectures apresentadas em 1962, publicado em A. Momigliano, As raízes clássicas da historiografia moderna, Bauru, SP: EDUSC, 2004, pp. 157-186.

${ }^{67}$ R. Di Donato, “Materiali per una biografia intellettuale di Arnaldo Momigliano”, in: Athenaeum Studi di Letteratura e Storia dell'Antichità. Volume Ottantatreesimo, Fascicolo 1, Università di Pavia, 1995, p. 242.
} 
percebida por Momigliano no decorrer da década de 1940, como indica a correspondência do historiador ao amigo Carlo Dionisotti. ${ }^{68}$

Uma análise dos desenvolvimentos da pesquisa de Momigliano sobre a paz e liberdade no mundo antigo e de seus desdobramentos a partir de 1946 (nos quais se incluem os estudos sobre a Antigüidade tardia apontados por Muray) requereria o acesso a uma série de textos do período não publicados (incluindo um volume manuscrito de 1947, intitulado Aspects of Roman Political Thought from Seneca to Tacitus), disponíveis apenas no acervo do Archivio Arnaldo Momigliano em Pisa. ${ }^{69}$

A partir de meados da década de 1940, como visto, a história da historiografia se tornaria o principal foco das pesquisas de Momigliano, sobretudo a partir de 1946, quando o historiador publicava o artigo Friedrich Creuzer and Greek Historiography e anunciava o seu novo tema de pesquisa aos colegas de Oxford. Murray identifica os estudos de Momigliano sobre a história da historiografia como a mais importante contribuição do historiador italiano para os estudos clássicos no mundo anglo-saxão, constituindo este, dentre os três temas de pesquisa por ele apontados, aquele de maior impacto no meio acadêmico inglês - motivo pelo qual, ao menos em parte, a história da historiografia constitui o campo com o qual Momigliano é comumente associado. Ainda que os leitores ingleses se sentissem mais familiarizados com os artigos de Momigliano sobre historiadores antigos - Tucídides, Heródoto, Políbio, Tácito etç a grande contribuição do historiador é identificada por Murray em seus estudos sobre historiadores modernos dos séculos XVIII e XIX, com menção aos artigos Ancient History and the Antiquarian (1950), Gibbon's Contribution to the Historical Method (1954) e George Grote and the Study of Greek History (1952) como os estudos de maior

\footnotetext{
${ }^{68}$ C. Dionisotti, Ricordo di Arnaldo Momigliano, Il Mulino, Bologna, 1989, pp. 97-108.

${ }^{69}$ Um inventário dos documentos disponíveis no Archivio Arnaldo Momigliano é fornecido em Giovanna Granata, L'Archivio Arnaldo Momigliano: inventario analitico, Edizione di storia e letteratura, Roma, 2006, com prefácio de Riccardo Di Donato. Uma grande parcela da correspondência do historiador é no arquivo mantida, assim como uma infinidade de rascunhos, anotações e textos de conferências não publicados. Entre o material relacionado ao tema paz e liberdade no mundo antigo, Granata fornece um inventário de 6 páginas contendo 40 itens (P-a 1-40, pp.3-9), seguido de um inventário do material relacionado às pesquisas que podem ser identificas como desdobramentos posteriores daquela sobre a paz e liberdade no mundo antigo, i.e. pesquisas sobre o pensamento político romano, no qual constam 26 itens (P-b 1-26, pp.10-13). Dentre os itens do último inventário, destaca-se o volume intitulado Aspects of Roman Political Thought from Seneca to Tacitus de 1947 (P-b 5-26, pp. 11-13, 372), mencionado por Di Donato em seu artigo "Materiali per una biografia intellettuale" (p. 242). O volume, de acordo com Di Donato, conteria anotações de um leitor editorial, manifestamente desfavoráveis, no que consiste o provável motivo de sua não publicação. Em nota, Anne Marie Meyer aponta a possibilidade dos comentários editoriais serem de autoria de Dan Davin da Oxford Clarendon Press.
} 
destaque, aqueles que teriam o estabelecido como um dos "grandes e mais relevantes mestres do método histórico”. ${ }^{70}$

Os estudos de Momigliano geralmente apontados como suas maiores contribuições no campo da história da historiografia correspondem, em grande medida, àqueles conduzidos no decorrer da década de 1950. É possível dizer que os estudos conduzidos nesta década culminariam com as Sather Classical Lectures, série de conferências ministradas pelo historiador em Berkley entre os anos de 1961 e 1962, sob o título The Classical Foundations of Modern Historiography. Estas conferências são comumente apontadas pelos comentadores da obra de Momigliano como o apogeu de sua maturidade intelectual e como evento crucial para o entendimento de seu desenvolvimento intelectual, sobretudo no campo da história da historiografia. ${ }^{71}$ No prefácio ao segundo volume dos Contributi, datado de abril de 1958, o próprio Momigliano fazia referência às Sather Lectures, então em processo de elaboração, prometendo oferecer, na ocasião destas, um quadro geral dos resultados obtidos a partir de sua pesquisa até aquele momento. ${ }^{72}$ A dispersão da obra de Momigliano, conseqüência de sua opção por estudos de extensão limitada, geralmente apresentados na forma de artigos e conferências, torna problemática a identificação dos temas de sua pesquisa e do desenvolvimento dos mesmos. Nesse sentido, as Sather Lectures oferecem uma série de estudos relacionados ao tema da história da historiografia reunidos em um todo coerente, em contraste com a compilação nos Contributi, nos quais os diversos artigos publicados por Momigliano aparecem dispostos de maneira pouco organizada. ${ }^{73}$

Os seis estudos que compõem The Classical Foundations of Modern History (1. A historiografia persa, a historiografia grega, a historiografia judaica, 2. A tradição herodoteana e a tradição tucidideana, 3. O surgimento da pesquisa antiquaria, 4. Fabio

\footnotetext{
${ }^{70}$ O. Murray, "Momigliano in England", in History and Theory, vol. XXX, n.4, Beiheft 30, 1991, pp. 5859.

${ }^{71}$ R. Di Donato, no prefácio a A. Momigliano, As raízes clássicas da historiografia moderna, Bauru, SP: EDUSC, 2004; e O. Murray, "Momigliano in England", in History and Theory, vol. XXX, n.4, Beiheft 30, 1991, pp. 57.

72 A. Momigliano, Secondo contributo alla storia degli studi classici, Roma: Edizioni di storia e letteratura, 1984, p. 9.

${ }^{73}$ As faltas relativas à organização da compilação dos artigos de Momigliano nos volumes dos Contributi são observadas por F. R. D. Goodyear em The Classical Review, New Ser., Vol.28, No.1. (1978), p.140; e pelo próprio Momigliano em A. Momigliano, Quinto contributo alla storia degli studi classici e del mondo antico, Roma: Edizioni di storia e letteratura, 1975, p. 9.
} 
Píctor e a origem da História Nacional, 5. Tácito e a tradição taciteana, 6. As origens da historiografia eclesiástica), desta forma, evidenciam a meta que Momigliano perseguia com sua pesquisa nos campos da historiografia antiga e moderna: traçar um quadro do desenvolvimento da escrita da história desde as crônicas persas até o presente, buscando relacionar o sentido da historiografia antiga aos seus principais desenvolvimentos na historiografia moderna. Para isso, Momigliano classifica as diversas formas de historiografia antiga (persa, judaica grega e romana), traçando suas influências através da Idade Média até o Renascimento. Na primeira conferência, o historiador analisa a influência da historiografia persa sobre as historiografias judaica e grega e os motivos que levaram, em última instância, a última a prevalecer. Identificando em ambas as tradições elementos que constituíam reminiscências do domínio persa, o que Momigliano identifica de distinto na historiografia judaica em relação à grega diz respeito à atitude crítica. O historiador judeu esteve, assim como o grego, comprometido com a verdade, porém com uma verdade divina, a verdade de seu deus, a qual possibilitava uma única tradição histórica. O historiador grego, por sua vez, perseguia uma verdade humana, motivo pelo qual necessitava estabelecer critérios de julgamento de acordo com os quais viria a decidir por uma entre duas ou várias diferentes versões apresentadas para um único evento. ${ }^{74}$ Este contraste entre o comprometimento do fiel e uma historiografia crítica e independente é um tema que permeia o texto das conferências, ${ }^{75}$ destacando-se sobretudo na última delas, na qual a história eclesiástica constitui o tema da discussão. ${ }^{76}$

Na segunda conferência, uma revolução ocorrida em algum ponto entre Hesíoso (700 a.C.) e Hecateu de Mileto (500 a.C.) é por Momigliano identificada: com Xenófanes, Hecateu e Heródoto, a validade da tradição histórica grega de Homero e Hesíodo seria questionada, e com isso se observaria o nascimento de uma historiografia crítica. Dois desenvolvimentos relativos a esta revolução são enfatizados por Momigliano: o primeiro deles político, a descoberta da importância da lei como fator de

\footnotetext{
${ }^{74}$ A. Momigliano, As raízes clássicas da historiografia moderna, Bauru, SP: EDUSC, 2004. pp.39, 62-3. Momigliano estende a discussão sobre a influência das crônicas persas sobre a historiografia grega e a historiografia judaica pós-exílica no artigo "Fattori orientali della storiografia ebraica e grega", originalmente publicado em 1965, reimpresso em A. Momigliano, Storia e storiografia antica, Il MulinoBologna, 1987, pp. 27-38.

${ }^{75}$ Averil Cameron chama a atenção para este tema e sua recorrência na obra em sua resenha da mesma, publicada em The Classical Review, Vol. 42, No. 2. (1992), pp. 420-421.

${ }^{76}$ A. Momigliano, As raízes clássicas da historiografia moderna, Bauru, SP: EDUSC, 2004, pp. 187-217.
} 
diferenciação nas sociedades humanas, e o segundo filosófico, a rebelião contra a tradição, a procura de novos princípios de explanação da realidade e a ascensão da dúvida como estímulo intelectual para novas descobertas. É na obra de Heródoto, que conhecemos melhor, onde se seguem e adquirem maior clareza os efeitos desta revolução. Momigliano dedica a Heródoto uma conferência efetuada em julho de 1957 na Anglo-American Conference of Historians, entitulada The Place of Herodotus in the History of Historiography, na qual discute a trajetória da obra do historiador em vista de seus antecessores, predecessores e comentadores, e da qual retomaria diversas questões para as Sather Lectures alguns anos depois. ${ }^{77}$

Heródoto, desde Cícero considerado o pai da história, viria a ser considerado também um exemplo de historiador pouco confiável. A má-fama de Heródoto teria, de acordo com Momigliano, implicações mais profundas, que transcenderiam o problema dos critérios de investigação histórica por ele adotados: “a vicissitude do conflito póstumo de Heródoto com seus detratores é um capítulo importante na história do pensamento histórico”. ${ }^{78}$ Tais implicações residem no fato do veredito sobre Heródoto na Antigüidade (perpetuado para períodos posteriores da história) ter sido determinado por seu sucessor, Tucídides, um crítico do modelo de história proposto por Heródoto:

Tucidides no creía que el intento herodoteano de describir hechos que el autor no había vivibo y de narrar la historia de hombres de los que no entendía la lengua pudiese tener futuro.(...) Tucídides era insensible al audaz intento de Heródoto de abrir a la investigación histórica las puertas del pasado y de países estranjeros. Pero debemos reconocer que cuando criticaba a Heródoto sabía lo que hacía. Estabelecía criterios más estrechos de fiabilidad histórica, si bien a riesgo de reducir la historia a um estrecho lapso de acontecimientos contemporáneos. $^{79}$

A realização mais importante de Tucídides teria sido, de acordo com Momigliano, haver convencido os seus sucessores de que a história é a história política. Como observou François Dosse, ainda no século XIX e inícios do XX, o modelo de historiografia dominante, positivista, de caráter eminentemente político, distante das outras ciências sociais, remetia ao modelo tucidideano. ${ }^{80}$ Tal modelo passa a ser combatido, ainda de acordo com Dosse, apenas nas primeiras décadas do século XX,

\footnotetext{
${ }^{77}$ A. Momigliano, La Historiografia Griega. Barcelona: Editorial Crítica, 1984. p.134-150.

${ }^{78}$ Ibidem, p.135.

${ }^{79}$ Ibidem, p.137.

80 François Dosse, A História em Migalhas: dos Annales à Nova História. Campinas: Editora da Universidade Estadual de Campinas, 1992, p.36.
} 
por intelectuais cujos principais traços se encontravam na rejeição total de tal historiografia dominante e da política. O modelo historiográfico proposto por estes intelectuais, representado principalmente pela escola dos Annales, ${ }^{81}$ triunfaria nos meados do século XX: distante da política, voltada para o econômico e social, e próxima das demais ciências humanas, a nova escola historiográfica encontraria em Heródoto seu modelo de historiador da Antigüidade. A partir daí a nova geração de historiadores, entre os quais se inclui Arnaldo Momigliano, reavaliaria a importância e o legado de Heródoto para a historiografia do século XX.

A discussão proposta por Momiligliano nos celebrados artigos Ancient Historian and the Antiquarian (1950) e Gibbon's Contribution to Historical Method (1954) é retomada na terceira das Sather Lectures. ${ }^{82}$ Os estudos antiquários, neste contexto, aparecem relacionados à tradição herodoteana. Ainda que, a partir de Tucídides, a história tenha sido associada à política, de forma que demais aspectos como a etnografia, a geografia, a religião, a arte etc, passaram a elementos marginais nas obras historiográficas, Momigliano percebe que tais aspectos não cessaram de ser estudados, passando a constituir o campo de interesse do antiquário:

A separação da história política dos estudos antiquários também é encontrada na Antigüidade. Ela de fato ocorreu quanto Tucídides criou a história política na época dos sofistas. É uma suposição justa dizer que se Heródoto tivesse permanecido como historiador modelo nunca teriam existido os antiquários. A sua curiosidade abraçava potencialmente todos os temas que mais tarde se tornaram campo do antiquário. ${ }^{83}$

Desta forma, a tradição dos antiquários, cuja origem Momigliano identifica nas pesquisas eruditas da Antigüidade, manteve-se viva no decorrer dos séculos como ramo paralelo à história. Momigliano estabelece uma relação entre o declínio dos antiquários e o surgimento da sociologia de Weber e Durkheim no século XIX, identificando esta

\footnotetext{
${ }^{81}$ Momigliano, que, no decorrer de sua formação na Universidade de Turim, esteve em contato próximo tanto com a history of ideas inglesa quanto com a Ideengeschichte alemã, como afirmou o próprio em artigo de 1972, intitulado “A Piedmontese View of the History of Ideas" (Sesto Contributo, pp. 329-335), teve pouco contato, num primeiro momento, com a escola francesa da histoire des idées, apontando como causa a escassa circulação desta entre 1920 e 1939 na Itália, onde, no período em questão, "toda a indagação nas représentations collectives que caracterizou a tradição Durkheim-Mauss-Halbwachs era praticamente desconhecida" e "Marc Bloch era conhecido (...) como um pioneiro nos estudo dos sistemas agrículas, mas não como autor de Les Róis thaumaturges". No mesmo artigo, Momigliano considera não haver, em qualquer outro país, algo comparável aos Annales ou ao estruturalismo como grandes movimentos de investigação histórica.

${ }^{82}$ A. Momigliano, Contributo alla storia degli studi classici, Roma: Edizioni di storia e letteratura, 1955, pp. 285-315, 321-339.

${ }^{83}$ A. Momigliano, As raízes clássicas da historiografia moderna, Bauru, SP: EDUSC, 2004, p.91.
} 
como a herdeira legítima dos estudos antiquários. Segundo o historiador, genes do antiquariato que teriam sido, segundo ele, transmitidos para a sociologia, para o estruturalismo e para a abordagem histórica que se estende para além das questões políticas com a superação do modelo tucidideano. Momigliano passaria a nutrir um crescente interesse pela sociologia e pela antropologia, sobretudo a partir da década de 1960, e tinha em alta conta o estruturalismo e a École des Annales como grandes movimentos de investigação histórica; sua metodologia e abordagem, entretanto, permaneceriam intocadas, repousando sobre a tradição erudita italiana de sua juventude, o respeito filológico positivista pela evidência, herdado da Altertumwissenschaft alemã, e a tradição filosófica croceana.

As duas conferências que se seguiam tocavam questões relacionadas a outros importantes temas da pesquisa de Momigliano. A primeira delas, sobre Tácito e o tacitismo, retoma discussões com as quais o historiador trabalhava já no início da década de 1940, as quais apareciam relacionadas, em um primeiro momento, aos estudos sobre a paz e liberdade no mundo antigo. Já a segunda, sobre Fábio Píctor e a origem da História Nacional, toca o tema das origens de Roma, ao qual Momigliano se dedicara, sobretudo, na década de 1960.

O procedimento habitual na ocasião das conferências apresentadas por Momigliano consistia na autorização imediata dos textos para a publicação. Este procedimento, entretanto, não seria adotado no caso das Sather Lectures (cuja publicação tradicionalmente ocorria em um período de poucos anos após apresentadas, em forma mais ou menos revisada, de acordo com Paul Cartledge). ${ }^{84}$ Momigliano retomou o texto da conferência em diversas ocasiões nas décadas que se seguiram à sua leitura em 1961-2, anotando, revisando e ampliando-o. Na ocasião de sua morte em 1987, o texto permanecia não publicado. De acordo com Di Donato, Momigliano tinha a intenção não apenas de aperfeiçoá-lo, mas também de compilar as notas e a bibliografia que apoiassem os temas de sua abordagem, tarefa que se mostraria difícil. O texto publicado em 1990 consiste em versão estabelecida por Anne Marie Meyer (executora literária da obra de Momigliano), compilado com base nos diversos manuscritos deixados pelo historiador. Esta versão corresponderia, de acordo com Di Donato em seu prefácio ao volume, o trabalho no estágio final deixado pelo autor, o

\footnotetext{
${ }^{84}$ Paul Cartledge, "Review of The Classical Foundations of Modern Historiography" in: The Journal of Hellenic Studies, Vol. 112. (1992), pp. 193-194.
} 
qual traria adições substanciais em relação ao texto original principalmente nos capítulos sobre Fábio Píctor e a origem da História Nacional (datadas de 1975) e sobre Tácito e a tradição taciteana (1978). A anotação do texto, que Momigliano deixara inconclusa, não foi incorporada ao texto publicado, que figura no livro desprovido de notas e bibliografia, acompanhado apenas por uma nota bibliográfica introdutória.

A versão original do texto das conferências e as diversas anotações, reformulações e adições posteriores, cujo acesso seria necessário para uma análise apropriada de seu desenvolvimento, encontram-se arquivadas no Archivio Arnaldo Momigliano em Pisa. ${ }^{85}$ Oswyn Murray, tendo tido acesso a estes documentos, observou a inexistência de alterações substanciais no texto no decorrer dos trinta anos entre sua elaboração e sua publicação. As adições a dois dos capítulos mencionadas por Di Donato em seu prefácio, de acordo com Murray, não alterariam os argumentos de forma significativa, e o mesmo é observado em relação a outras alterações, correções e adições menores. Diante disso, Murray propõe que o motivo da não publicação do texto não seria a insatisfação de seu autor em relação às idéias nele contidas, e que o período da formação intelectual de Momigliano teria se estendido até o ano de 1961, quando já teria um mapa claro da história da historiografia ocidental e uma visão bem formada de seu significado, de forma que seu conhecimento se aprofundaria nas três décadas seguintes, porém sua metodologia e abordagem pouco se alterariam no período. ${ }^{86}$

As faltas do texto das conferências de Momigliano foram apontadas por diversos comentadores. Woolf, em sua resenha de The Classical Foundations of Modern Historiography, chama a atenção para o caráter estritamente positivista da abordagem do problema das origens da historiografia moderna oferecida por Momigliano, que “aceita em grande medida a equação da modernidade na historiografia com o uso de documentos, avaliando antigos pelos critérios da filologia pós-niebuhreana”. Chama a atenção também para os estudos recentes sobre os estilos de Tucídides, Heródoto, Luciano e outros historiadores antigos, estudos que destacam o elemento retórico nas obras destes historiadores e a influência deste elemento na historiografia posterior. ${ }^{87}$

\footnotetext{
85 Giovanna Granata, L’Archivio Arnaldo Momigliano: inventario analitico, Edizione di storia e letteratura, Roma, 2006, pp. 14-21. Os documentos relacionados às Sather Lectures correspondem aos itens P-c 1-36 do inventário.

${ }^{86}$ O. Murray, "Momigliano in England”, in History and Theory, vol. XXX, n.4, 1991, pp. 62-3.

87 D. R. Woolf, "Review of The Classical Foundations of Modern Historiography”, in: Renaissance Quarterly, Vol. 45, No. 4. (Winter, 1992), pp. 830-833.
} 
Konstan, de forma análoga a Woolf, chama a atenção para as mudanças na apreciação do método histórico tucidideano ocorridas no período de trinta anos entre a composição das Sather Lectures de Momigliano e sua publicação. A ênfase na exatidão e na preocupação com a objetividade de Tucídides teria cedido às investigações de sua arte narrativa, da maneira como moldava seu material de acordo com imperativos éticos e retóricos. Konstan aponta acertadamente que Momigliano ignora tais desenvolvimentos em sua abordagem não em função de ignorá-los, mas por ser antipático em relação a eles, de forma que o texto tal qual publicado em 1990 não estaria em desacordo com o pensamento maduro do historiador. De fato, como discutido anteriormente, Momigliano teria repudiado o estudo retórico da história, defendendo a objetividade desta e a sua submissão sine qua non aos limites impostos pela evidência. Além disso, “(..) if Thucydides is not an example of a pure historian," observa Konstan, "there must be doubts about the lineage traced to him, and the determination of influences becomes complicated, perhaps hopelessly so". ${ }^{88}$

Os limites e faltas do texto de Momigliano, que no presente aparecem como evidentes em vista dos estudos realizados desde a sua elaboração no final da década de 1950 e início da década de 1960 não constituem, assim, o motivo da insatisfação de Momigliano em relação ao mesmo. ${ }^{89} \mathrm{O}$ historiador esteve ciente de tais desenvolvimentos e manteve as convicções expressas em suas conferências apesar deles. Um motivo distinto para a não publicação do texto é sugerido por Cartledge em sua resenha do livro, o qual diz respeito à extensão limitada do estudo em relação à enorme produção do historiador:

My own feeling, though, is that the chief reason for disquiet lay in the lectures' very theme, which by then had become and was to remain as it were his life's work. Momigliano took scholarship - not just his own - deadly seriously, and he surely believed that his life's work deserved better, or at any rate more than

\footnotetext{
${ }^{88}$ D. Konstan, "Review of The Classical Foundations of Modern Historiography", in: History and Theory, Vol. 31, No. 2. (May, 1992), pp. 224-230.

${ }^{89} \mathrm{O}$ quadro da linhagem que une a tradição herodoteana à tradição antiquaria e aos estudos sociológicos do século XIX e XX oferecido por Momigliano, também não é desprovido de faltas. Com relação ao tema, uma série de discussões é oferecida no volume "Momigliano and Antiquarianism: Foundations of the Modern Cultural Sciences”, editado por Peter N. Miller, no qual diversos estudiosos contribuem com os textos de suas conferências apresentadas em simpósio realizado na Williams Andrews Clark Library, em Los Angeles - incluindo Peter Burke, Anthony Grafton, Riccardo Di Donato e Marc Fumaroli entre outros. Estes se tratam, porém, de estudos bastante recentes, realizados na última década.
} 
a mere 150 pages of middle-aged summation, no matter how elegantly concise and suggestive, nor how enormous the range of reference. ${ }^{90}$

Da mesma forma que a obra definitiva de Momigliano relacionada ao tema de sua maturidade, a história da historiografia, não seria publicada no decorrer de sua vida, a obra sobre o tema da juventude do historiador, a paz e a liberdade no mundo antigo, também jamais seria finalizada. É importante ressaltar que a opção de Momigliano por estudos de extensão limitada não consistia, como Di Donato, Goodyear e outros comentadores dão a entender, em uma escolha consciente após as monografias da juventude na Itália. Até a segunda metade da década de 1940, Momigliano ainda perseguia o objetivo de compor uma obra definitiva a respeito do tema de seus estudos. É com a progressiva realização das dificuldades inerentes à empreitada e, em última instância, a falta de êxito em concluí-la, que o autor limitaria sua produção a estudos de extensão limitada.

Da ocasião de convites para a apresentação de séries de conferências, como no caso das Sather Classical Lectures, Momigliano valia-se para apresentar um quadro mais amplo que evidenciasse os sentidos de sua pesquisa, dispersos em inúmeros artigos publicados em diferentes periódicos e compilados sem um critério estabelecido nos volumes dos Contributi. Da mesma forma que The Classical Foundations, também os volumes The Development of Greek Biography (Carl Newer Jackson Classical Lectures em 1968) e Alien Wisdom (Trevelyan Lectures em 1973 e Abraham Flexner Lectures em 1974) consistem em textos originalmente preparados para conferências. Estes estudos, ainda que de maior extensão, continuavam possibilitando apenas uma discussão prévia sobre os temas abordados, sem pretensões de apresentar um quadro definitivo sobre os mesmos. Isso Momigliano deixa claro no prefácio ao texto das Sather Lectures, no qual propõe que "seis conferências não podem exaurir um assunto. Se isto fosse possível, eu não deveria ter aceitado o convite de ministrá-las, pois conheço muito pouco do território tão vasto que escolhi por tema”. ${ }^{91}$

Em 1971, quando escrevia o prefácio ao Quinto Contributo, Momigliano já possuía consciência de que a organização sistemática de sua obra e a identificação dos

\footnotetext{
${ }^{90}$ P. Cartledge, "Review of The Classical Foundations of Modern Historiography", in The Journal of Hellenic Studies, Vol. 112. (1992), pp. 193-194.

${ }^{91}$ A. Momigliano, As raízes clássicas da historiografia moderna, Bauru, SP: EDUSC, 2004, p. 8.
} 
temas e nexos de sua pesquisa seria um trabalho que caberia a uma geração futura de historiadores:

Come un critico amichevole ha giustamente osservato, la raccolta dei miei saggi, che ora giunge alla sua quinta porzione, avrebbe dovuto essere ordinata più sistematicamente e razionalmente. Ma cio sarebbe stato possibile solo dopo mia morte... ${ }^{92}$

${ }^{92}$ A. Momigliano, Quinto contributo alla storia degli studi classici e del mondo antico, Roma: Edizioni di storia e letteratura, 1975, p. 9. 


\section{Considerações Finais}

A presente dissertação busca oferecer um quadro no qual o desenvolvimento dos temas da pesquisa de Arnaldo Momigliano sejam identificados e analisados em relação ao seu desenvolvimento intelectual e ao contexto histórico de sua produção. As abordagens de Momigliano da história da paz e liberdade no mundo antigo e da história da historiografia são, dessa forma, analisadas no contexto político da Itália fascista, da perseguição aos judeus e do exílio do historiador na Inglaterra, considerando sua formação e buscando identificar as influências que definiram seu pensamento.

Tratando-se esta de uma pesquisa cujas fontes se limitam a materiais publicados (textos sobre Arnaldo Momigliano e textos de autoria de Arnaldo Momigliano), seu foco recai, inevitavelmente, sobre a obra do historiador, à qual, sempre que possível, se buscou relacionar informações biográficas e relativas ao contexto de sua produção. Uma pesquisa que propusesse elucidar as condições que possibilitaram a Momigliano, com suas escolhas e temas de pesquisa na presente dissertação discutidas, tornar-se um dos expoentes da historiografia do século XX, requereria acesso a um tipo diferente de fonte, que possibilitasse perscrutar o(s) meio(s) acadêmico(s) em que o historiador esteve inserindo e suas relações com outras figuras deste(s) meio(s), i.e. o aspecto social de sua trajetória acadêmica.

Neste sentido, a vasta correspondência pessoal do historiador reunida no Archivio Arnaldo Momigliano ${ }^{1}$ muito provavelmente constitui material valiosíssimo não apenas para o desenvolvimento das questões esboçadas nesta dissertação, mas também para o surgimento de questões de caráter diverso. Uma documentação referente à relação de Momigliano com o Warburg Institute e outras instituições seria em igual medida valiosa. Tais explorações, entretanto, deverão constituir pesquisa futura.

\footnotetext{
${ }^{1}$ Giovanna Granata, L'Archivio Arnaldo Momigliano: inventario analitico, Edizione di storia e letteratura, Roma, 2006, pp. 203-255.
} 


\section{Referências Bibliográficas}

\section{Obras de Arnaldo Momigliano}

MOMigliANO, Arnaldo. Prime linee di storia della tradizione Maccabaica. Torino: Casa Editrice Giovanni Chiantore, 1934.

. Filippo il Macedone. Saggio sulla storia greca del IV secolo AC. Firenze: Felice Le Monnier, 1934.

Claudius: The Emperor and His Achievement. Oxford: Ckarendon Press, 1934.

Letteratura, 1955.

. Seccondo contributo alla storia degli studi classici. Roma: Edizioni di Storia e Letteratura, 1960.

. The Conflict between Paganism and Christianity in the Fourth Century: Essays edited by Arnaldo Momigliano. Oxford-Warburg Studies, Oxford: Clarendon Press, 1963.

. Studies in Historiography. London: Weidenfeld and Nicolson, 1966.

- Terzo contributo alla storia degli studi classici e del mondo antico. Roma: Edizioni di Storia e Letteratura, 1966.

Quarto contributo alla storia degli studi classici e del mondo antico. Roma: Edizioni di Storia e Letteratura, 1969.

. The Development of Greek Biography: Four Lectures. Cambridge: Harvard University Press, 1971.

Alien Wisdom: The Limits of Hellenization. Cambridge University Press, 1975.

The Faults of the Greeks (Daedalus). Harvard University, 1975.

Q Quinto contributo alla storia degli studi classici e del mondo antico. Roma: Edizioni di Storia e Letteratura, 1975.

Essays in Ancient and Modern Historiography. Wesleyan University, 1977.

. Sesto contributo alla storia degli studi classici e del mondo antico. Roma:

Edizioni di Storia e Letteratura, 1980.

Settimo contributo alla storia degli studi classici e del mondo antico. Roma:

Edizioni di Storia e Letteratura, 1984. 
- Ottavo contributo alla storia degli studi classici e del mondo antico. Roma: Edizioni di Storia e Letteratura, 1987.

. On Pagans, Jews and Christians. Wesleyan University, 1987.

Press, 1991.

. The Classical Foundations of Modern Historiography. University of California . Nono contributo alla storia degli studi classici e del mondo antico. Roma: Edizioni di Storia e Letteratura, 1992.

. How to Reconcile Greeks and Trojans. University of California Press, 1983.

_. Sui fondamenti della storia antica. Torino: Giulio Einaudi editore, 1984.

_. Storia e storiografia antica. Bologna: Il Mulino, 1987.

. Philippe de Macedoine: essai sur l'histoire grecque du iv siecle av.j.-c. Paris: L'eclat, 1992.

- Ensayos de Historiografía Antigua y Moderna. Mexico: Fondo de Cultura Económica, 1993.

A.D. Momigliano: Studies on Modern Scholarship. Ed. G.W. Bowersock and T.J. Cornell. University of California Press, 1994.

Ensayos de Historiografía Antigua y Moderna. México D. F.: Fondo de Cultura Económica, 1997.

. Pace e libertá nel mondo antico: lezioni a Combridge gennaio-marzo 1940. La Nuova Italia Editrice, 1996

. As Raízes Clássicas da Historiografia Moderna. Bauru, SP: EDUSC, 2004. 


\section{Textos e artigos sobre Arnaldo Momigliano ou relacionados à sua obra}

BRISCOE, John. Alien Wisdom. In: The Classical Review, New Ser., Vol. 28, No. 1. (1978), pp. 109-110.

BROWN, P. Arnaldo Dante Momigliano 1908-1987. In: Proceedings of the British Academy, 74, 1988, p.405-442.

BRUNT, P. A. "Momigliano and Historical Method”. In: The Classical Review, New Ser., Vol. 17, No. 3. (Dec., 1967), pp. 358-360.

CANFORA, Luciano. Ideologías de los Estudios Clássicos. Madrid: Akal, 1991.

CARMINE, Ampolo. Storie greche: La formazione della moderna storiografia sugli antichi Grechi. Torino, Einaudi, 1999.

CHRIST, Karl. Neue Profile der alten Geschichte, Darmstadt, 1990, p.248-294.

History and Theory, Vol. 17, No. 3. (Oct., 1978), pp. 327-336.

. "Arnaldo Momigliano and the history of historiography". In: History and Theory, vol. XXX, n.4, Beiheft 30, 1991, pp. 5-12.

CRACCO, Ruggini L. (ed.). Omaggio ad Arnaldo Momigliano. Storia e storiografia sul mondo antico. Convegno di studio (Cuneo-Caraglio, 22-23 ottobre 1988). Come: 1989 (Biblioteca di Athenæum, 11).

DI DONATO, Ricardo. "Materiali per una biografia intellettuale di Arnaldo Momigliano.” In: Athenaeum Studi di Letteratura e Storia dell'Antichità. Volume Ottantatreesimo, Fascicolo 1, Università di Pavia, 1995, pp. 213-244.

"Nuovi materiali per uma biografia intellettuale di Arnaldo Momigliano.” In: Rendiconti Morali Accademia dei Lincei, 11 (2000), n. 1, pp. 391-392.

DIONISOTTI, Carlo. “Arnaldo Momigliano e Croce.” In: Belfagor 43, 1989. pp. 617641.

Ricordo di Arnaldo Momigliano. Il Mulino, Bologna, 1989.

DREWS, Robert. Classical Philology, vol. 76, No. 1. (Jan., 1981), pp. 65-57.

EASTON, Stewart C. The American Historical Review, Vol.61, No.1 (Oct. 1955), pp.96-97.

FINLEY, M. I. History and Theory, Vol. 7, No. 3. (1968), pp.355-367.

The use and abuse of history. London : Chatto and Windus, 1975

GINZBURG, Carlo. Mitos, emblemas, sinais: Morfologia e História. 2 ed. São Paulo: Cia. das Letras, 1989. 
2007.

O fio e os rastros: verdadeiro, falso, fictício. São Paulo: Companhia das Letras,

GRANATA, Giovanna. L’Archivo Arnaldo Momigliano: inventario analítico. Edizioni di storia e letteratura, Roma, 2006.

GRAFTON, A. “Arnaldo Momigliano e la storia degli studi classici.” In: Rivista storica italiana, 107, 1955, pp. 91-109.

"Momigliano at the Warburg: the origins of a style." In: American Scholar, vol.

73, n. 4, 22 September 2004, pp. 129-133.

HAMMOND, Mason. The American Historical Review, Vol. 72, No.4 (Jul., 1967), pp. 1354-1355.

HARTOG, François. Os antigos, o passado e o presente. Brasília: Universidade de Brasília, 2003.

KAGAN, David. “Arnaldo Momigliano and the human sources of history.” In: The New Criterion, v. 10, n. 7, March 1992.

MILLER, P. N. (org.). Momigliano and Antiquarianism: Foundations of the Modern Cultural Sciences. Toronto: University of Toronto Press, 2007.

MURRAY, Oswyn. The Journal of Roman Studies, Vol. 67, (1977), pp177-178.

"Arnaldo Momigliano in England.” In: History and Theory, vol. XXX, n.4, Beiheft 30, 1991, pp. 49-64.

OOST, Stewart Irvin. Classical Philology, Vol. 52, No. 1. (Jan., 1957), p.47.

PATLAGEAN, E. "Les Contributi d'Arnaldo Momigliano: portrait d'un historien dans ses paysages.” In: Annales ESC, 37, 1982, p.1004-1013.

PHILLIPS, M. S. "Reconsiderations on History and Antiquarianism: Arnaldo Momigliano and the Historiography of Eighteenth-Century Britain.” In: Journal of the History of Ideas 57.2 (1996) 297-316.

POLVERINI, Leandro (org.) Arnaldo Momigliano nella storiografia del novecento. Edizioni di storia e letteratura, Roma, 2006.

REINHOLD, Meyer. Classical Philology, Vol. 73, No. 4. (Oct., 1978), pp. 359-361.

STARR, Chester G. The American Historical Review, Vol.81, No.5 (Oct. 1976), pp.1079-1080

STEINBERG, M.P. (org.) "The Presence of the Historian: Essays in Memory of Arnaldo Momigliano.” In: History and Theory. Beiheft 30, 1991. 


\section{Bibliografia Geral}

ANDO, Clifford. Imperial Ideology and Provincial Loyalty in the Roman Empire. Berkeley, Los Angeles, and London: University of California Press, 2000.

BUNZL, Martin. Real History: reflections on historical practice. London: Routledge, 1997.

CARBONELL, Charles-Olivier. La historiografía. México: Fondo de Cultura Económica, 1986. [ed. orig.francês: 1981]

CANFORA, Luciano. Ideologías de los Estudios Clássicos. Madrid: Akal, 1991.

CARMINE, Ampolo. Storie greche: La formazione della moderna storiografia sugli antichi Grechi. Torino, Einaudi, 1999.

CERTEAU, Michel de. A escrita da história. Rio de Janeiro: Forense Universitária, 1982.

CHARTIER, Roger. À beira da falésia: a história entre certezas e inquietude. Porto Alegre: Ed. da UFRGS, 2002.

CHESNEAUX, Jean. Devemos fazer tabula rasa do passado? - sobre história e os historiadores. Trad. Marcos A. da Silva. São Paulo: Ática, 1995. (Fundamentos, 109)

COLLINGWOOD, R. G. The Idea of History. Oxford University Press, 1951.

CREUZER, Friedrich. Erodoto e Tucidide. Palermo: Sallerio, 1994.

CROCE, Benedetto. Theory and History of Historiography. London: George G. Harrap \& Co., 1921. Etica e Politica. Bari: Gius, Laterza \& Figli, 1945. Filosofia, poesia, storia. Milano- Napoli: Riccardo Ricciardi Editore, 1952.

- La Historia como Hazaña de la Libertad. Mexico: Fondo de Cultura Exonómica, 1960.

CROIX, G. Ste. The Class Struggle in the Ancient Greek World: From the Archaic Age to the Arab Conquests. London: Duckworth, 1981.

DOSSE, François. A História em Migalhas. Bauru (SP): EDUSC, 2003.

FELICE, Renzo De. Storia degli ebrei italiani sotto il fascismo. Torino: Giulio Einaidi Editore, 1977.

FINLEY, M. I. Ancient History: Evidence and Models. London: Chatto \& Windus, 1985.

. Problemi e metodi di storia antica. Laterza, Bari, 1987. 
. History and Theory, Vol. 7, No. 3. (1968), pp.355-367.

. The use and abuse of history. London: Chatto and Windus, 1975

Aspectos da antiguidade. São Paulo: Martins Fontes, 1991.

(org.) O legado da Grécia. Brasília: Unb, 1998.

FUETER, Eduard. Historia de la historiografia moderna. Buenos Aires: Nova, 1953. $2 \mathrm{v}$.

FUSCO, Renato de. Storia dell' idea di storia. Napoli: Edizioni Scientifiche Italiane, 1998.

GARLAND, Yvon. Guerre et Economie en Grèce Ancienne. Paris: La Decouverte, 1999.

GARNSEY, Peter; SALLER, Richard. The Roman Empire: Economy, Society and Culture. Londres: Duckworth, 1987

GIBBON, E. The Decline and Fall of the Roman Empire. Newark: Associated University Presses, 1999.

GINZBURG, Carlo. Relações de força: história, retórica, prova. Trad. Jônatas Batista Neto. São Paulo: Companhia das Letras, 2002. 1989.

Mitos, emblemas, sinais: Morfologia e História. 2 ed. São Paulo: Cia. das Letras, 2007.

O fio e os rastros: verdadeiro, falso, fictício. São Paulo: Companhia das Letras,

GRANT, Michael. The Ancient Historians. Nova York : Barnes and Nobles, 1994.

HARTOG, François. “A testemunha e o historiador.” In: PESAVENTO, Sandra Jatahy (org.). Fronteiras do Milênio. Porto Alegre: Ed. da UFGRS, 2001. p.11-41.

O espelho de Heródoto. Belo Horizonte: UFMG, 1999.

(org). A História de Homero a Santo Agostinho. Belo Horizonte : UFMG, 2001.

HUSKINSON, J. Experiencing Rome; culture, identity and power in the Roma Empire. London: Routledge, 2000.

IGGERS, Georg G. Historiography in the Twentieth Century: from Scientific Objectivity to the Postmodern Challenge. London: Wesleyan University Press, 1997.

JACOBITTI, Edmund E. Hegemony before Gramsci: The Case of Benedetto Croce. In: The Journal of Modern History, Vol. 52, No. 1 Mar., 1980. pp. 66-8

JAEGER, Werner. Paidéia. São Paulo: Martins Fontes, 1995. 
LANDON, J. E. Empire of Honour: The Art of Government in the Roman World. Oxford University Press, 1997.

LE GOFF, Jacques (org.). A História Nova. São Paulo: Martins Fontes, 1998.

LEPENIES, Wolf. As três culturas. São Paulo: Edusp, 1996.

MILLAR, Fergus (org.). The Roman Empire and its Neighbours. New York: Delacorte Press, 1967.

MORGAN, M. Gwyn. The History Teacher, Vol.12, No.1 (Nov., 1978), pp. 131-132.

PALMEIRA, Miguel Soares. Moses Finley e a "economia antiga": A produção social de uma inovação historiográfica. São Paulo: Universidade de São Paulo, 2007. (Tese de Doutorado inédita defendida no Departamento de História da Universidade de São Paulo).

PAYEN, Pascal. "Comment Résister à la Conquête: temps, espace et récit chez Hérodote.” In: Révue des Études Grecques, 108, 1995, pp. 308-338.

PIRES, F. M. "Prologue historiographique et proème épiques.” In: Quaderni di storia, 58, luglio-dicembre 2003, pp. 73-94.

Mithistória. São Paulo: Humanitas, 1999.

Percepções da Atenas ancestral. São Paulo: Universidade de São Paulo, 1983. (Tese de Doutorado inédita defendido no Departamento de História da Universidade de São Paulo).

PURCELL, Nicholas; HORDEN, Peregrine. The Corrupting Sea: A Study of Mediterranean History. Oxford: Blackwell, 2000.

RINGER, Fritz. O declínio dos mandarins alemães. São Paulo: Edusp, 1997.

ROSTOVTZEFF, M. Greece. Londres : Oxford, 1963.

SEALEY, R. Thycydides, Herodotos, and the Causes of War. In: The Classical Quarterly, VII, 1/2, jan. - abril 1957, pp. 1-12.

SILVA, Rogério Forastieri da. História da historiografia: capítulos para uma história das histórias da historiografia. Bauru (SP): Edusc, 2001.

SNELL, Bruno. The Discovery of the Mind. Nova York : Dover, 1960.

SOUTHGATE, Beverly. History: what and why? - ancient, modern, and postmodern perspectives. London: Routledge, 1998.

STAHL, H.-P. Thucydides: Man’s Place in History. Swansea : Wales, 2002.

VERNANT, Jean-Pierre. As origens do pensamento grego. Rio de Janeiro : Bertrand Brasil, 1996.

VEYNE, Paul. Como se escreve a história. Brasília: Ed. Universidade de Brasília, 1992. 
Quando a verdade histórica era tradição e vulgata. In: - Acreditaram os gregos nos seus mitos? [Lisboa]: Edições 70, 1987. p.17-28.

WATERS, K. H. Heródoto el hitoriador. Cidade do México: Fondo de Cultura Económica, 1996.

WEBER, Max. As Causas do Declínio da Cultura Antiga. In Cohn, Gabriel (org.) Weber: Sociologia. Coleção Grandes Cientistas Sociais. São Paulo: Ática, 1997.

WOOLF, G. Becoming Roman: The Origins of Provincial Civilization in Gaul. Cambridge University Press, 1998. 